\title{
Protein Homeostasis Networks and the Use of Yeast to Guide Interventions in Alzheimer's Disease
}

\author{
Sudip Dhakal $\mathbb{D}$ and Ian Macreadie * $\mathbb{D}$ \\ School of Science, RMIT University, Bundoora, Victoria 3083, Australia; sudip.dhakal@rmit.edu.au \\ * Correspondence: ian.macreadie@rmit.edu.au; Tel.: +61-3-9925-6627
}

Received: 29 September 2020; Accepted: 26 October 2020; Published: 28 October 2020

\begin{abstract}
Alzheimer's Disease (AD) is a progressive multifactorial age-related neurodegenerative disorder that causes the majority of deaths due to dementia in the elderly. Although various risk factors have been found to be associated with AD progression, the cause of the disease is still unresolved. The loss of proteostasis is one of the major causes of AD: it is evident by aggregation of misfolded proteins, lipid homeostasis disruption, accumulation of autophagic vesicles, and oxidative damage during the disease progression. Different models have been developed to study AD, one of which is a yeast model. Yeasts are simple unicellular eukaryotic cells that have provided great insights into human cell biology. Various yeast models, including unmodified and genetically modified yeasts, have been established for studying AD and have provided significant amount of information on AD pathology and potential interventions. The conservation of various human biological processes, including signal transduction, energy metabolism, protein homeostasis, stress responses, oxidative phosphorylation, vesicle trafficking, apoptosis, endocytosis, and ageing, renders yeast a fascinating, powerful model for AD. In addition, the easy manipulation of the yeast genome and availability of methods to evaluate yeast cells rapidly in high throughput technological platforms strengthen the rationale of using yeast as a model. This review focuses on the description of the proteostasis network in yeast and its comparison with the human proteostasis network. It further elaborates on the $\mathrm{AD}$-associated proteostasis failure and applications of the yeast proteostasis network to understand $\mathrm{AD}$ pathology and its potential to guide interventions against AD.
\end{abstract}

Keywords: Alzheimer' disease; yeast; proteostasis; unfolded protein response; autophagy; ubiquitin proteasome system

\section{Introduction}

Alzheimer's disease (AD) is an age-related progressive neurodegenerative disorder, which accounts for 60 to $80 \%$ deaths resulting from dementia in elderly people [1]. AD has been found to be a multifactorial disease with several causes being hypothesized and investigated [2]. However, amyloid beta $(\mathrm{A} \beta)$ mediated toxicity and its clearance from the neuronal environment has been the most popular area of AD research for the last three decades, as amyloid plaques are the most significant pathological hallmarks of the disease [3]. Memory deficits and cognitive impairment due to loss of neurons resulting in cortical atrophy accompanied by presence of amyloid plaques and neurofibrillary tangles are present in people with $\mathrm{AD}[4,5]$. Depending upon the time of occurrence of first symptoms, $\mathrm{AD}$ victims have been classified into early onset $\mathrm{AD}$ (EOAD) and late onset $\mathrm{AD}$ (LOAD). Most AD patients (90-98\%) have late onset disease with symptoms appearing after the age of 65 years [5]. AD pathology has been divided into familial autosomal dominant inheritance forms ( $<1 \%$ of total AD cases) and a sporadic multifactorial category (majority of cases) [6]. The mutations in amyloid precursor protein (APP) and two presenilin genes (PSEN1 and PSEN2) have been found to be associated with the familial form [7]. On the contrary, the multifactorial sporadic disease is more 
genetically complex, and cannot be attributed by any single risk factor or cause. More than 20 risk loci have been identified from previous studies involving genome wide association studies (GWAS) and linkage analysis (Figure 1). Most of these important AD-associated risk loci are associated with $\mathrm{A} \beta$ mediated toxic pathways, while other risk loci are associated with immune function, endocytosis, synapsis, and lipid metabolism [8]. Interestingly, all these cellular processes associated with AD pathology are somehow dependent on cellular protein homeostasis [9-13].

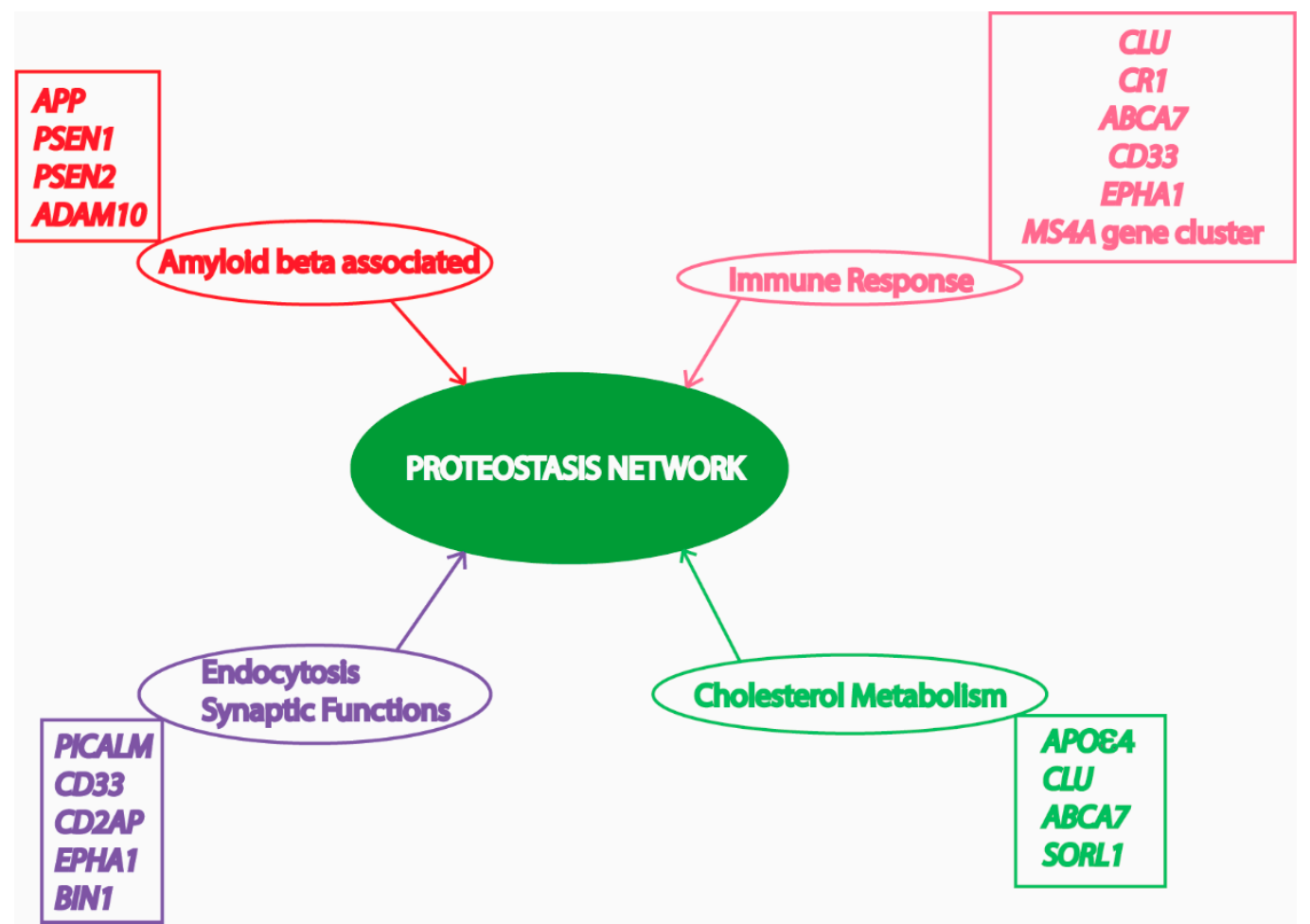

Figure 1. Risk factors/loci and associated cellular processes identified by genome wide association studies (GWAS) involved in Alzheimer's Disease (AD) converge to the proteostasis network. APP, amyloid precursor protein; PSEN1, presenilin 1; PSEN2, presenilin 2; ADAM10, ADAM metallopeptidase domain 10; CLU, clusterin; CR1, complement C3b/C4b receptor 1; ABCA7, ATP binding cassette subfamily A member 7; CD33, CD33 molecule; MS4A, membrane spanning 4-domains A; PICALM, phosphatidylinositol binding clathrin assembly protein; CD2AP, CD2 associated protein; EPHA1, EPH receptor A1; BIN1, bridging integrator 1; APO 4 4, apolipoprotein E4; SORL1, sortilin related receptor 1 . Various risk loci have been identified by GWAS to be associated with AD. Some of these risk loci are clustered to important cellular processes in this figure to depict their relationship with the proteostasis network, highlighting its significance in AD pathology. Previous studies suggest an important role of the proteostasis network in cellular processes associated with AD, including amyloid formation pathway, immune response mechanisms, vesicle trafficking, endocytosis, and lipid metabolism.

The intracellular neuronal environment of AD patients is characterized by loss of proteostasis, mitochondrial dysfunction, impaired mitophagy, oxidative damage, genetic instability, impaired protein clearance, amyloidosis, loss of synapsis, disruption of lipid homeostasis, biometal distribution alteration, and energy failure [2]. Most of these defects are found associated with various events in the $\mathrm{AD}$ brain; however, the majority are thought to be the consequence of $\mathrm{A} \beta$ overproduction and aggregation [14]. These intracellular cues are also conserved in yeast cells with more than $60 \%$ of its genes having human homologs or at least one conserved domain [15]. The major yeast models used for AD studies involve Saccharomyces cerevisiae [16]. These models for AD studies have been very important in understanding the role of conserved fundamental eukaryotic processes in $\mathrm{AD}$ 
pathology to develop methods to find potential therapeutics [17-23]. The conservation of signal transduction, energy metabolism, proteostasis network, lipid metabolism, vesicle trafficking, oxidative phosphorylation, stress response, longevity, and cell death in yeast models makes it highly appropriate for studies on AD pathology and treatment $[15,24]$. Various yeast models have been used in the past to understand $\mathrm{AD}$ progression and to find interventions to prevent and cure the disease [25]. This review reiterates on the comparison of the yeast protein clearance mechanisms with human counterparts and hints at the application of yeast to address important aspects of AD pathology and drug discovery.

\section{Protein Homeostasis Network in Yeast}

Constant turnover of cellular components inside a cell is of the utmost importance for adaptation during changing cellular environment, which interplays with multiple cellular processes required for cell survival [26]. Numerous proteins are coordinately functioning in a cell to fulfill the survival requirements of the cell. Protein synthesis, proper folding, protein quality control, transport of the protein to the target location, and proper function of the protein in its target depends on the cellular environment. Defects in protein processing or folding can cause abnormal aggregation of proteins possibly leading to disease if not repaired. These aberrations are detected by the cell and repaired by the protein quality control mechanisms governed by the proteostasis network. In fact, at least two types of chaperones in a eukaryotic system are controlling the protein folding: chaperones linked to protein synthesis (CLIPS) and chaperones expressed during stress [27]. In eukaryotes, chaperone mediated protein disaggregation machinery allows disaggregation of the protein aggregates and helps to correct the misfolding or partial unfolding of the protein [28]. However, failure to fold the proteins in correct conformation and inability of the chaperones to refold the aggregated proteins leads to activation of protein clearance mechanisms. Generally, protein clearance in the eukaryotic cell is controlled by three major molecular pathways: unfolded protein response, ubiquitin proteasome system, and autophagy (Figure 2) [29]. Various intrinsic and extrinsic factors play a crucial role in the regulation of these pathways inside a cell. Ageing has been found to be one important reason for the loss of proteostasis and subsequent disease development in neuronal cells due to accumulation of unwanted misfolded proteins [30]. During AD pathology, deposits of amyloid plaques and neurofibrillary tau tangles are the evidences that support the loss of protein homeostasis as leading cause of the disease [31]. Restoring the protein homeostasis has been hypothesized to cure or prevent AD and similar diseases [32]. This review elaborates on molecular mechanisms of unfolded protein response, autophagy, and ubiquitin proteasome system in yeast and their relevance to study human counterparts in relation to AD progression. Furthermore, we suggest possible applications of the knowledge of proteostasis network originating from yeast to find ways to explore AD pathology and develop drugs. 


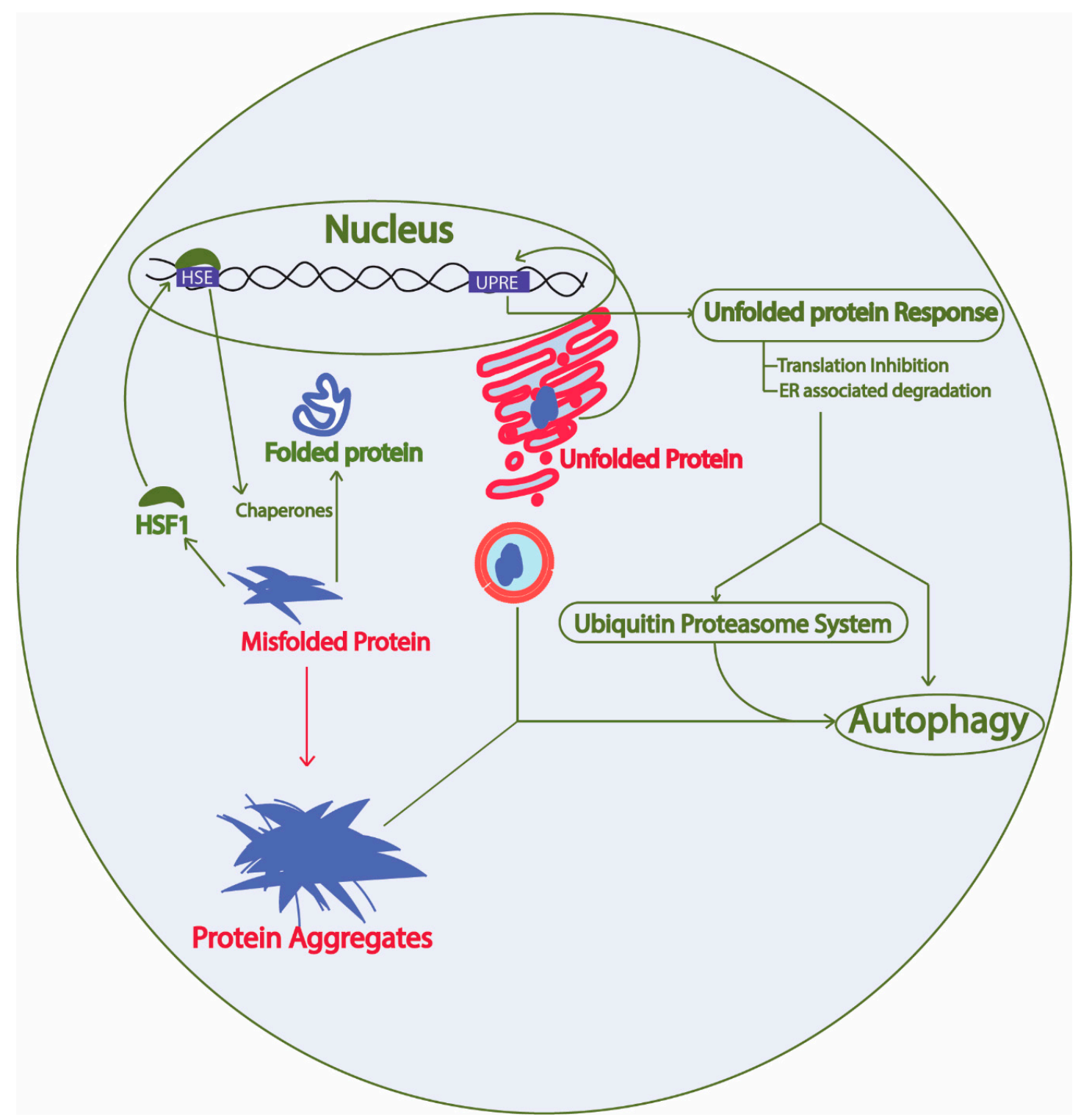

Figure 2. Proteostasis network involves protein synthesis, protein folding, heat shock response, unfolded protein response, ubiquitin proteasome system, and autophagy. Green arrow, protective; Red arrow, toxic; HSF1, heat shock factor 1; HSE, heat shock elements; UPRE, unfolded protein response elements. The proteostasis network involves protein synthesis machinery, protein folding, protein quality control, protein transport, and the overall turnover of proteins inside a cell. The presence of misfolded proteins in the cytosol trigger HSF1 activation, which activates promoters with HSE and results in expression of heat shock proteins that are either involved in protein disaggregation and refolding or clearance of the unwanted proteins through protein quality control mechanisms. Similarly, the presence of aberrations in the ER lumen causing unfolded protein formation leads to activation of the unfolded protein response and downstream activation of the protein quality control system.

\subsection{Unfolded Protein Response Conserved in Yeast}

Production of a protein is not sufficient for the proper biological function of protein; the expressed protein needs to be folded in its native form to be functional [33]. Most soluble proteins are folded directly in cytoplasm with the help of molecular chaperones [34], while the secreted proteins including hydrophobic membrane proteins pass through the endoplasmic reticulum (ER) and Golgi complexes and require correct folding [35]. Correct folding and maturity of the protein depends highly on the 
nutrient conditions, ER calcium homeostasis, availability of molecular chaperones, redox status, and cell health [36]. However, failure to maintain cellular homeostasis results in unfolded and misfolded proteins that are prone to aggregation. The formation of unfolded and misfolded proteins in the ER lumen triggers proteotoxic stress and activates the stress response pathway-the unfolded protein response (UPR) [37]. UPR is a mechanism by which the cells reduce the proteotoxic stress generated in the ER during protein folding and processing [36]. At least two types of stress response are activated during such conditions in mammalian cells. At first, the UPR attenuates protein translational activity by phosphorylating the translational initiation factor $2 \alpha$ (eIF $2 \alpha$ ) and activating the mRNA decay mechanism [38]. On the other hand, it increases protein folding, and activates autophagy and the ubiquitin proteasome system for degradation of undesired protein products [39]. On the other hand, UPR also activates the oxidative stress response to aid cell survival under ER stress [40].

\subsubsection{Yeast Unfolded Protein Response}

The UPR is conserved from the simplest eukaryotic unicellular yeast to complex human beings [36]. In yeast, the UPR involves sensing of unfolded proteins with the help of the stress sensor inositol requiring element 1 protein (Ire1p) in the ER lumen (Figure 3). The Ire1p is an ER localized type I transmembrane protein with its luminal domain sensing the protein folding environment in the ER and its cytosolic part comprising protein kinases and RNases activity. The luminal portion of the Ire1p is constantly bound with the chaperone binding immunoglobulin protein (Bip/GRP78) in normal conditions hindering the activation of Ire1p [41]. Any aberrations in the protein folding environment is indicated by the presence of unfolded and misfolded proteins in the ER or disassociation of Bip from Ire1p luminal part. The binding of Bip with Ire1p plays a crucial role in regulating UPR in yeast [42]. The oligomerization of Ire1p followed by its autophosphorylation is an essential activation signaling process that activates the cytosolic Ire1p RNase activity. The activation of Ire1p RNase activity leads to HAC1 (homologous to ATF/CREB1) mRNA splicing [43]. In normal conditions, HAC1 mRNA contains an inhibitory intron at the $3^{\prime}$ end, which renders $H A C 1$ mRNA unfavorable for translation and remains inhibited by yeast protein two 1 (Ypt1p) [44]. Upon ER stress, the RNase activity of cytosolic part of Ire1p cleaves the specific inhibitory intron present in the $3^{\prime}$ end of the HAC1 mRNA. Moreover, re-joining of the cleaved active $H A C 1$ mRNA ends is accomplished by tRNA ligase (Rlg1p) protein [45]. This processing of the $H A C 1$ mRNA leads to its higher translation to Hac1p protein. Hac1p, protein encoded by the translationally active HAC1 mRNA, is a basic leucine zipper (bZIP) transcription factor that recognizes specific unfolded protein response elements (UPRE) sequences ( $5^{\prime}$-CACCTTG), present in the promoters of target genes including the Hac1 gene. Although Haclp is sufficient for activation of UPR in yeast, complex interaction with other transcription factors involving interplay with Hac1p may result in activation of the UPRE promoters [46]. The upregulation of the promoters with UPRE region and subsequent UPR are protective to cells leading to the degradation of the unfolded protein by activating ER associated degradation (ERAD) [47]. The expression of stress resistance genes, autophagy genes and restoration of the energy metabolism further enhances cell survival. In addition, ER stress also reduces protein synthesis by inhibiting the eukaryotic translation initiation factor, which has been reported to be involved in assembly of mRNA-protein (RNP) granules [48]. At least two types of RNP granules, namely processing bodies (P-bodies) and stress granules, are found to be produced during various stresses including ER stress in yeast [49]. Formation of these granules, specifically the stress granules, are typically cytoprotective in nature and is an integral part of protein quality control. 


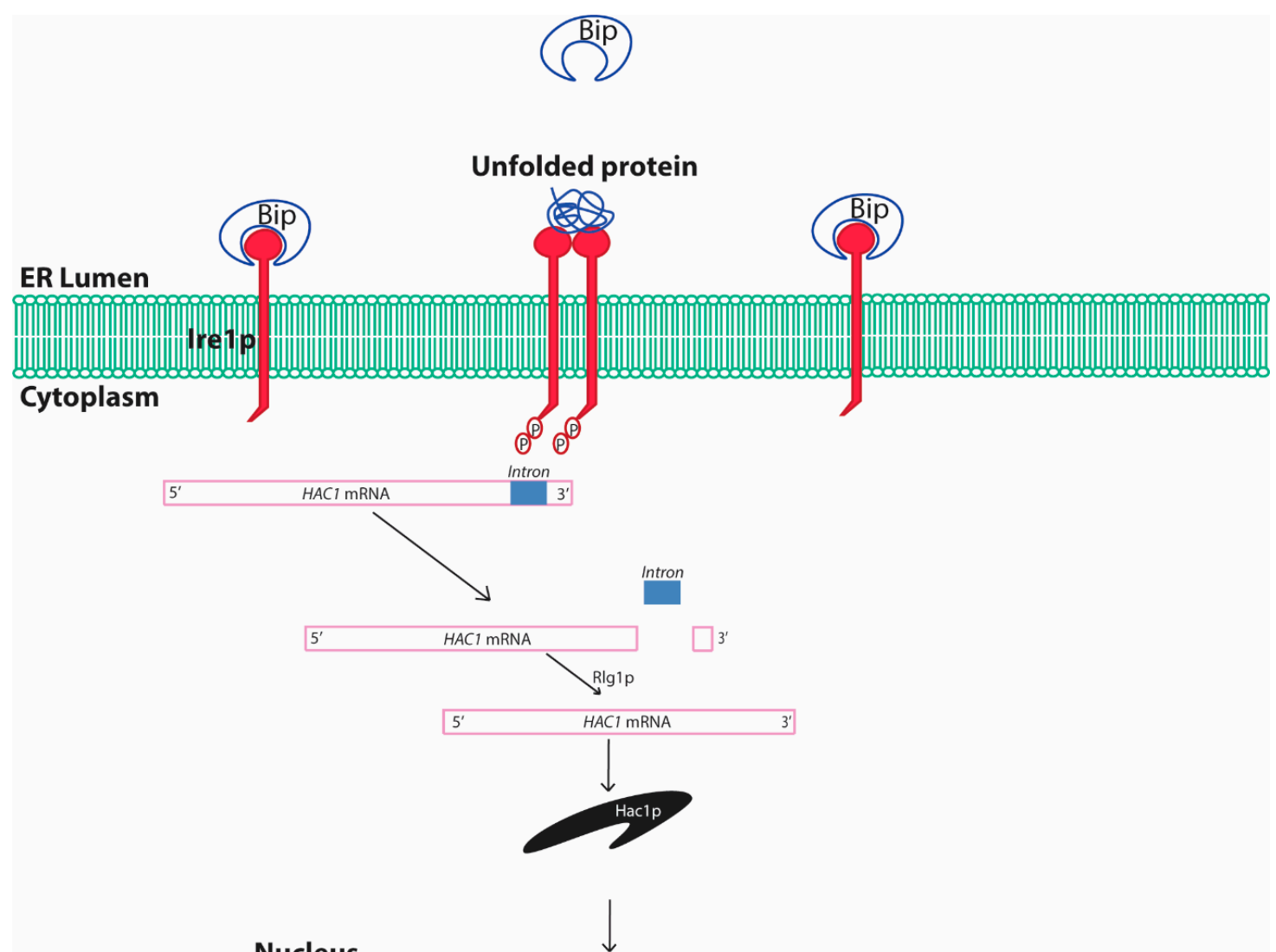

Nucleus

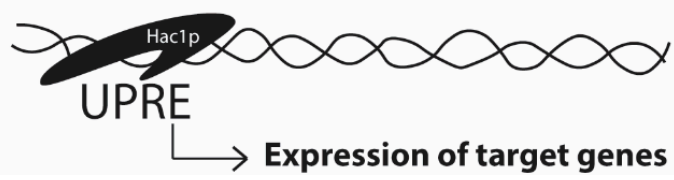

Figure 3. Schematic diagram showing unfolded protein response in yeast cells. Bip, binding immunoglobulin protein; ER, endoplasmic reticulum; Ire1, inositol requiring element 1; HAC1, Homologous to ATF/CREB1; Rlg1p, tRNA ligase protein; UPRE, unfolded protein response elements. The presence of unfolded/misfolded proteins in the ER lumen is recognized by the yeast Ire1 sensor protein that activates the specific cytosolic endonuclease activity cleaving the inhibitory intron of HAC1 mRNA and rendering HAC1 mRNA translationally active. Hac1p protein translates and translocates to the nucleus, where it recognizes the characteristic cis-acting elements in the promoter regions of certain genes referred to as UPRE and increases expression of genes under control of such promoters. The process is referred to as the UPR.

\subsubsection{Human Unfolded Protein Response}

The human homologs of Bip, Ire1p, and Hac1p share high similarity in their molecular mechanism and the activation of important cytoprotective processes in mammalian cells, providing a rationale to explore yeast as model organism to study UPR and ER stress (Table 1). However, the mammalian UPR is more complex than the yeast UPR. The mammalian UPR is accomplished by three mechanisms dependent on three sensors, namely, inositol requiring element 1 (IRE1), PKR-like ER kinase (PERK), and activating transcription factor (ATF6), in the ER lumen [50]. The conserved IRE1 signaling in mammals causes the splicing of X-box binding protein 1 (XBP1, the Hac1p functional homolog in mammals) transcription factor mRNA and downstream signaling [51]. Additionally, the PERK protein is similar to Ire1p of yeast in the luminal part, while it is different in the cytosolic part. The activation of PERK leads to activation of the protein kinase domain that phosphorylates the eukaryotic translation initiation factor 2 alpha (eIF2 $\alpha$ ), which reduces the protein translational activity [52]. In humans as 
well, the inhibition of protein translation is associated with the formation of RNP granules, which is generally cleared by either protein disaggregation machinery or by autophagy [49]. In contrast, ATF6 sensors are absent in yeast and function very differently from the conventional response. Upon ER stress, ATF6p is transported to Golgi complexes, where it is cleaved by two proteases, specificity protein 1 (SP1) and specificity protein 2 (SP2), to release a fragment ATF6f. The ATF6f fragment translocates to the nucleus and acts as a bZIP transcription factor, which binds to the DNA in the promoter region of the target genes involved in ER associated degradation (ERAD) [52]. Meanwhile, the failure to protect cells from chronic ER stress may result in the activation of activating transcription factor 4 (ATF4)/C/EBP homologous protein (CHOP) signaling. The ER stress-induced CHOP signaling activates proapoptotic genes and reduces antiapoptotic gene expression [53]. Simultaneously, CHOP signaling also upregulates expression of growth arrest and DNA damage 34 (GADD34p) protein phosphatase, which dephosphorylates eIF $2 \alpha$ enhancing protein synthesis, thereby inducing formation of reactive oxygen species as a result of compromised ER folding environment and chronic ER stress $[54,55]$. The overall effect of chronic ER stress is characterized by the activation of programmed cell death via apoptosis [56].

Table 1. Conserved proteins of yeast unfolded protein response and their human homologs.

\begin{tabular}{cccc}
\hline Yeast Protein & Human Homolog & Function & References \\
\hline Kar2p/Bip/Grp78p & HSPA5/BiP/GRP78 & $\begin{array}{c}\text { Chaperone regulating activation } \\
\text { of Ire1p }\end{array}$ & {$[42,57]$} \\
\hline Ire1p & IRE1 $\alpha$ & Stress sensing and endonuclease & activity \\
\cline { 2 - 4 } Hac1p & PERK & Stress sensing and protein kinase & {$[58]$} \\
\hline Sui2p & XBP1p & $\begin{array}{c}\text { UPRE binding and expression of } \\
\text { target genes }\end{array}$ & {$[59]$} \\
\hline Ypt1p & eIF2 $\alpha$ & $\begin{array}{c}\text { Eukaryotic translation initiation } \\
\text { factor involved in protein } \\
\text { translation regulation }\end{array}$ & {$[60]$} \\
\hline
\end{tabular}

\subsection{Ubiquitin Proteasome System}

The ubiquitin proteasome system (UPS) is one of the major protein quality control systems that controls intracellular protein homeostasis by facilitating degradation of unwanted proteins [61]. The presence of the UPS in both the cytosol and nucleus indicates its significance during transcriptional and post-translational regulation of genes. The UPS plays a significant role in neuronal synapsis by regulating the DNA damage repair, neurotransmitter release, and membrane receptor turnover [62-64]. The degradation of protein due to UPS is dependent on the cellular processes and energy status. In nutrient rich conditions, the availability of energy helps proteasomal degradation of polyubiquitinated target proteins, while nutrient starvation lowers the cellular energy levels, which may restrict the UPS and enhance autophagy to save energy [65].

Protein turnover through the UPS occurs through ubiquitin-mediated proteasomal degradation (Figure 4). Proteins to be degraded are polyubiquitylated by three enzymes: ubiquitin activating enzyme E1, ubiquitin conjugating enzyme E2, and ubiquitin ligating enzyme E3 ligases [66]. Most of the yeast enzymes that are involved in ubiquitination of a substrate protein are conserved in humans (Tables 2 and 3). The first step in the UPS is ATP-dependent activation of ubiquitin by binding it to the E1 enzyme [67]. Ubiquitin is a protein of 76 amino acids having at least seven highly conserved lysine residues (K6, K11, K27, K29, K33, K48, and K63) from yeast to humans [61]. The activated ubiquitin is transferred to E2, which in conjunction with E3 enzyme transfers the ubiquitin molecule to the substrate proteins [68]. The ubiquitin conjugated to substrate protein can be further elongated with several ubiquitin forming polyubiquitinated proteins, which determines the fate of the protein 
inside a cell. In general, lysine residues are the ubiquitin binding sites in a substrate protein; however, serine, threonine, and cysteine have also been involved in ubiquitin conjugation. The binding of one ubiquitin molecule in a substrate protein is referred to as monoubiquitylation, while the binding of multiple ubiquitin molecules to a substrate is associated with its degradative fate. Meanwhile, recent studies have revealed that several monoubiquitylated proteins are also found to be degraded by the proteasome [69]. Ubiquitin can bind to a substrate protein at multiple lysine residues within the amino acid chain leading to multiubiquitination or it can elongate the existing monoubiquitinated sites making a chain of polyubiquitin. The polyubiquitylation of a substrate protein is the characteristic degradative signal, which is recognized by the proteasome [70].

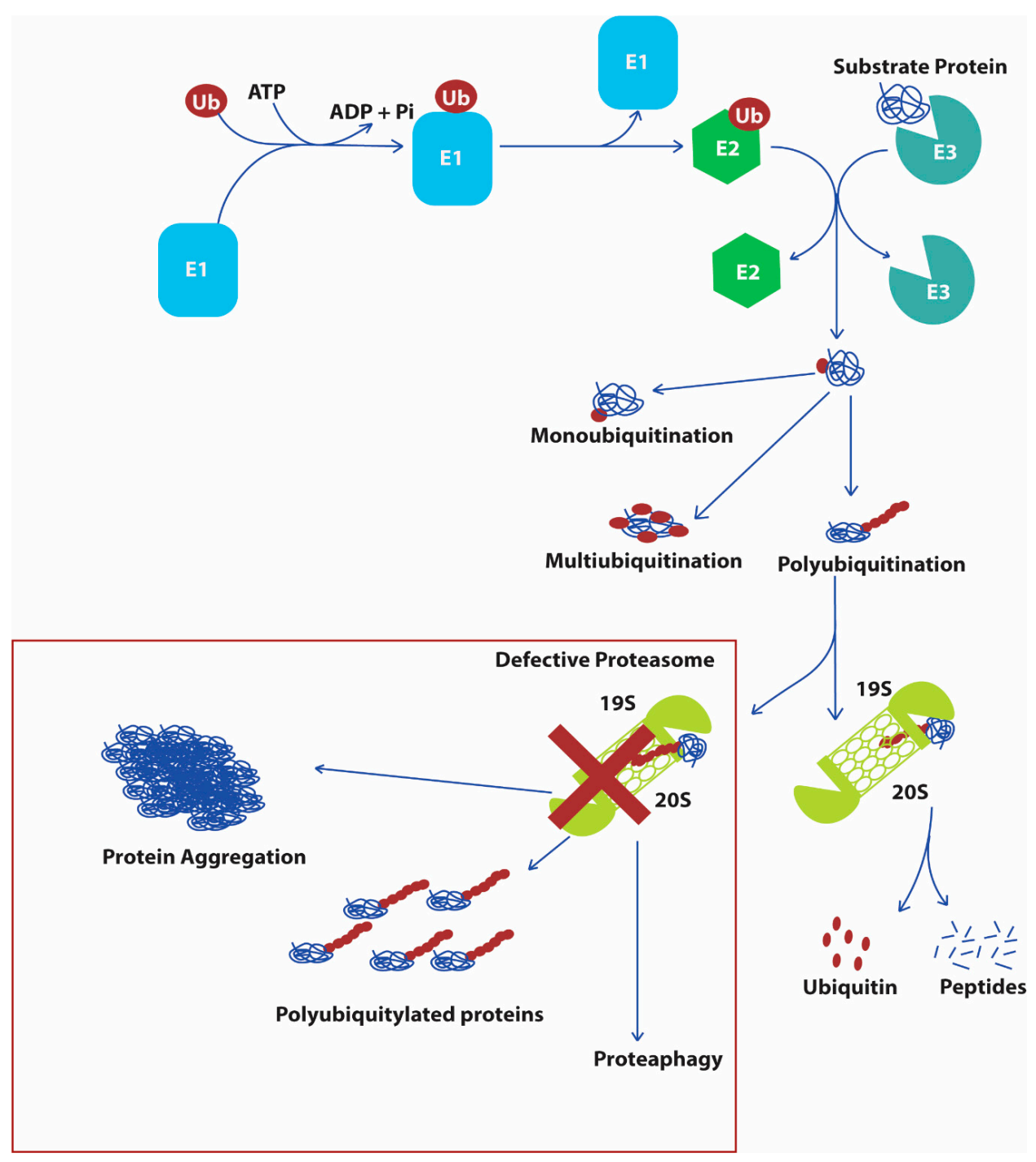

Figure 4. Schematic diagram showing degradation of substrate protein by the UPS and fates of defective proteasomal system. Ub, ubiquitin; ATP, adenosine triphosphate. The first step in ubiquitin proteasome system requires the activated E1 activating enzyme to activate the ubiquitin. Following the activation of ubiquitin, E1 enzyme transfers the activated ubiquitin molecule to E2 conjugating enzyme. At the same time, E3 ligating enzyme conjugates with the substrate protein, which is then conjugated with ubiquitin bound to E2 enzyme. The chain of ubiquitin is elongated by multiple cycles of ubiquitination. The ubiquitinated proteins are then recognized and degraded by the 265 proteasome, while the failure to degrade the polyubiquitinated proteins due to defective proteasome may result in protein aggregation, abundance of polyubiquitinated proteins, and impaired protein turnover. The defective proteasome may get recycled through proteaphagy. 
Table 2. Yeast ubiquitins, E1 activating enzymes, and E2 conjugating enzymes conserved in humans that are involved in polyubiquitylation of substrate protein.

\begin{tabular}{|c|c|c|c|}
\hline Yeast Protein & Human Homolog & Functions of Proteins in Yeast & Ref \\
\hline \multicolumn{4}{|c|}{ Ubiquitin } \\
\hline $\begin{array}{l}\text { Ubi1, Ubi2, Ubi3, } \\
\text { Ubi4 }\end{array}$ & UBB, UBC & Cellular stress response and ubiquitination of proteins & [71] \\
\hline \multicolumn{4}{|c|}{ Ubiquitin activating E1 enzyme } \\
\hline Uba1 & UBA1 & Ubiquitin-mediated protein degradation & [72] \\
\hline \multicolumn{4}{|c|}{ Ubiquitin conjugating E2 enzyme } \\
\hline Ubc1 & UBE2K & $\begin{array}{l}\text { Major E2 enzyme works together with Ubc4, } \\
\text { degradation of short-lived and aberrant proteins, } \\
\text { increases protein during DNA stress, cellular stress } \\
\text { response, vesicle biogenesis, and ERAD }\end{array}$ & {$[73-75]$} \\
\hline Ubc2 & UBE2A, UBE2B & $\begin{array}{l}\text { K63 ubiquitination mediated oxidative stress response; } \\
\text { turnover of Rpn4; DNA repair }\end{array}$ & {$[76,77]$} \\
\hline Ubc3 & UB2R1, UB2R2 & $\begin{array}{l}\text { Regulation of cell cycle progression; protein } \\
\text { abundance during DNA stress }\end{array}$ & {$[78,79]$} \\
\hline Ubc4, Ubc5 & $\begin{array}{l}\text { UB2D1, UB2D2, UB2D3, } \\
\text { UB2D4 }\end{array}$ & $\begin{array}{l}\text { Major E2 enzyme works together with Ubc1; } \\
\text { degradation of abnormal calmodulin and H3 histone; } \\
\text { regulates levels of DNA polymerase }\end{array}$ & [80-82] \\
\hline Ubc6 & UB2J2 & ERAD; ER membrane (Cytosolic) resident E2 enzyme & [83] \\
\hline Ubc7 & UB2G1, UB2G2 & $\begin{array}{l}\text { ERAD; inner nuclear membrane associated } \\
\text { degradation; chromatin assembly }\end{array}$ & [84] \\
\hline Ubc8 & UBE2H & Regulates gluconeogenesis & [85] \\
\hline Ubc9 & UBC9 & $\begin{array}{l}\text { Anaphase promoting complex cyclosome mediated } \\
\text { proteolysis; Cell cycle progression }\end{array}$ & [86] \\
\hline Ubc10 & UB2D1, UB2D2 & Peroxisome biogenesis & [87] \\
\hline Ubc13 & UBE2N & DNA damage repair, DNA stress response & [88] \\
\hline
\end{tabular}

Table 3. Yeast ubiquitin E3 ligating enzymes conserved in humans.

\begin{tabular}{|c|c|c|c|}
\hline Yeast Protein & Human Homolog & Functions of Proteins in Yeast & Ref \\
\hline \multicolumn{4}{|c|}{ Ubiquitin ligase E3 enzyme } \\
\hline Hul4 & HECTD2 & HECT ubiquitin ligase & [89] \\
\hline Hul5 & UBE3C & $\begin{array}{l}\text { HECT ubiquitin ligase; essential for elongation of } \\
\text { polyubiquitin chains in the misfolded proteins during heat } \\
\text { shock response; ERAD }\end{array}$ & [90-92] \\
\hline Rsp5 & NEDD4L & $\begin{array}{l}\text { NEDD4 family E3 ubiquitin ligase; regulates heat shock } \\
\text { response; endocytosis and vesicle trafficking. }\end{array}$ & [92-94] \\
\hline Tom1 & HUWE1 & $\begin{array}{l}\text { HECT ubiquitin ligase; export of mRNA to cytosol; balancing } \\
\text { histones; cell cycle regulation. }\end{array}$ & {$[81,95,96]$} \\
\hline Ufd4 & TRIP12 & E3 ubiquitin ligase; involved in DNA stress. & [79] \\
\hline Asr1 & RNF165 & $\begin{array}{l}\text { Ubiquitin E3 ligase; regulates RNA Polymerase II subunits; } \\
\text { actin cytoskeleton organization }\end{array}$ & {$[97,98]$} \\
\hline Bre1 & RNF40 & $\begin{array}{l}\text { E3 ubiquitin ligase conjugates with Rad6p and regulates } \\
\text { histone methylation; oxidative stress response mediated } \\
\text { proteolysis; double stranded break repair; pre-mRNA splicing. }\end{array}$ & {$[76,99-101]$} \\
\hline Dma1, Dma2 & RNF8 & E3 ubiquitin ligase; regulates level of eIF2 & [102] \\
\hline Ssm4/Doa10 & MARCHF6 & $\begin{array}{l}\text { RING-CH domain E3 ligase associated with ER and nuclear } \\
\text { membrane; involved in ERAD, }\end{array}$ & [84] \\
\hline Hel2 & ZNF598 & $\begin{array}{l}\text { RING finger E3 ubiquitin ligase; excess histone clearance; } \\
\text { involved in ribosome associated quality control }\end{array}$ & {$[103,104]$} \\
\hline Hrd1 & SYVN1 & $\mathrm{H} 2$ ring finger E3 ubiquitin ligase; involved in UPR and ERAD & [105] \\
\hline Fyv10 & MAEA & $\begin{array}{l}\text { Ring finger ubiquitin ligase; inhibits gluconeogenesis; } \\
\text { anti-apoptotic; part of glucose-induced degradation-deficient } \\
\text { (GID) complex }\end{array}$ & [106-108] \\
\hline
\end{tabular}


Table 3. Cont.

\begin{tabular}{|c|c|c|c|}
\hline Yeast Protein & Human Homolog & Functions of Proteins in Yeast & Ref \\
\hline $\operatorname{Irc20}$ & SHPRH & $\begin{array}{l}\text { Ring finger E3 ubiquitin ligase; involved in non-homologous } \\
\text { end joining DNA repair pathway }\end{array}$ & [109] \\
\hline Nam7 & UPF1 & $\begin{array}{l}\text { RING-related E3 ubiquitin ligase; nonsense mutation } \\
\text { mediated mRNA decay }\end{array}$ & [79] \\
\hline Mot2 & CNOT4 & $\begin{array}{c}\text { Ubiquitin ligase of CCR4-NOT complex; regulates } \\
\text { transcription, post transcriptional modifications and mRNA } \\
\text { degradation }\end{array}$ & {$[110,111]$} \\
\hline Pep5 & VPS11 & $\begin{array}{l}\text { Histone E3 ligase that enhances degradation of excess } \\
\text { histones; vacuole biogenesis. }\end{array}$ & {$[103,112]$} \\
\hline Pex2 & PEX2 & RING finger peroxisomal E3 ubiquitin ligase & [113] \\
\hline Pex10 & PEX10 & Peroxisomal membrane associated E3 ubiquitin ligase & [114] \\
\hline Pex12 & PEX12 & RING finger peroxisomal E3 ubiquitin ligase & [115] \\
\hline Pib1 & FYCO1 & $\begin{array}{l}\text { RING finger ubiquitin ligase of endosome and vacuole } \\
\text { membranes }\end{array}$ & [116] \\
\hline Psh1 & TRIM25 & $\begin{array}{c}\text { E3 ubiquitin ligase for degradation of centromere binding } \\
\text { protein }\end{array}$ & [117] \\
\hline Rad5 & HLTF & $\begin{array}{l}\text { Ubiquitin ligase or DNA helicase involved in DNA damage } \\
\text { stress response }\end{array}$ & {$[118,119]$} \\
\hline Rad18 & RAD18 & $\begin{array}{l}\text { E3 ubiquitin ligase complexes with PCNA; involved in post } \\
\text { replication repair of DNA }\end{array}$ & {$[120,121]$} \\
\hline Rmd5 & RMND5A & $\begin{array}{l}\text { RING finger E3 ubiquitin ligase; inhibits gluconeogenesis; part } \\
\text { of GID complex }\end{array}$ & [106] \\
\hline Rkr1 & LTN1 & $\begin{array}{l}\text { RING domain E3 ubiquitin ligase; part of ribosome quality } \\
\text { control complex; clearance of defective mRNA }\end{array}$ & [122-124] \\
\hline San1 & RNF13 & $\begin{array}{c}\text { E3 ubiquitin ligase; involved in selective clearance of defective } \\
\text { aggregate prone proteins }\end{array}$ & {$[125,126]$} \\
\hline Slx8 & RNF10 & RING domain ubiquitin ligase; required for genomic integrity & [127] \\
\hline Snt2 & PHF14 & $\begin{array}{l}\text { RING finger E3 ubiquitin ligase; oxidative stress response; } \\
\text { degradation of excess histones. }\end{array}$ & {$[103,128]$} \\
\hline Ubr2 & UBR2 & Cytoplasmic E3 ubiquitin ligase & [129] \\
\hline Prp19 & PRPF19 & $\begin{array}{c}\text { E3 ubiquitin ligase; DNA damage response; pre-mRNA } \\
\text { splicing }\end{array}$ & {$[130,131]$} \\
\hline Ufd2 & UBE4B & $\begin{array}{l}\text { Polyubiquitylation of substrate protein; stress response; ERAD } \\
\text { of misfolded proteins }\end{array}$ & {$[132,133]$} \\
\hline Hel1 & ARIH1 & RING finger E3 ubiquitin ligase; clearance of excess histones & [103] \\
\hline Itt1 & RNF14 & E3 ubiquitin ligase; modulates termination of translation & [134] \\
\hline Cdc53 & CUL1 & Cullin family E3 ubiquitin ligase; cell cycle progression & {$[135,136]$} \\
\hline Cul3 & CUL3 & $\begin{array}{c}\text { Cullin family E3 ubiquitin ligase; degradation of RNA } \\
\text { Polymerase II }\end{array}$ & [137] \\
\hline Rtt101 & CUL4 & $\begin{array}{l}\text { Cullin subunit of a E3 ubiquitin ligase complex; cell cycle } \\
\text { progression; double stranded break repair; rRNA decay }\end{array}$ & {$[138,139]$} \\
\hline Skp1 & SKP1 & $\begin{array}{l}\text { Major component of SCF (Skp1-Cullin-F-box) E3 ubiquitin } \\
\text { ligase complex; V-ATPase assembly; cell cycle progression; } \\
\text { DNA replication stress response }\end{array}$ & {$[79,140,141]$} \\
\hline Elc1 & ELOC & $\begin{array}{c}\text { E3 ubiquitin ligase; genomic repair; degradation of RNA } \\
\text { polymerase II }\end{array}$ & {$[137,142]$} \\
\hline Hrt1 & RBX1 & Part of various ubiquitin ligase SCF complex & [143] \\
\hline Cdc4 & FBXW7 & $\begin{array}{l}\text { F-box protein; part of SCF-Cdc4 ubiquitin ligase complex; } \\
\text { ubiquitination of cyclin-dependent kinases }\end{array}$ & {$[144,145]$} \\
\hline Met30 & FBXW7 & $\begin{array}{l}\text { Essential protein; F-box protein; part of SCF complex; heavy } \\
\text { metal stress response; Cell cycle }\end{array}$ & {$[146,147]$} \\
\hline
\end{tabular}


Table 3. Cont.

\begin{tabular}{|c|c|c|c|}
\hline Yeast Protein & Human Homolog & Functions of Proteins in Yeast & Ref \\
\hline Ela1 & ELOA & $\begin{array}{l}\text { F-box protein heterodimerizes with Elc1; subunit of } \\
\text { Elongin-Cullin-Socs ubiquitin ligase complex }\end{array}$ & {$[137,148,149]$} \\
\hline Hrt3 & FBX9 & F-box protein of SCF ubiquitin ligase complex & [150] \\
\hline Rav1 & DMXL1 & $\begin{array}{l}\text { Part of RAVE complex; V-ATPase assembly; role in } \\
\text { endocytosis }\end{array}$ & {$[151,152]$} \\
\hline Saf1 & HERC2 & F-box protein involved in cell quiescence & [153] \\
\hline Cdc27 & CDC27 & $\begin{array}{c}\text { Part of anaphase promoting complex (APC)/cyclosome, a } \\
\text { ubiquitin ligase complex involved in the degradation of } \\
\text { anaphase inhibitors }\end{array}$ & [154] \\
\hline Cdc16 & CDC16 & $\begin{array}{l}\text { Part of APC/C, a ubiquitin ligase complex involved in the } \\
\text { degradation of anaphase inhibitors }\end{array}$ & [155] \\
\hline Cdc23 & $\mathrm{CDC} 23$ & $\begin{array}{l}\text { Part of APC/C, a ubiquitin ligase complex involved in the } \\
\text { degradation of anaphase inhibitors }\end{array}$ & [155] \\
\hline Doc1/Apc10 & ANAPC10 & Subunit of APC; Substrate ubiquitination & {$[156,157]$} \\
\hline
\end{tabular}

The eukaryotic proteasome is a conserved multi-subunit proteolytic $26 \mathrm{~S}$ complex composed of two subcomplexes: 20S core complex and 19S regulatory complex (Table 4). The abundance of characteristic polyubiquitinated proteins are positive regulators of proteasome assembly and formation [158]. The substrate entry into the core $20 \mathrm{~S}$ complex is regulated by the regulatory $19 \mathrm{~S}$ complex, which plays an important role in the recognition of the polyubiquitylated substrate protein, deubiquitylation of the substrate protein, unfolding the target protein, opening the gate of the core complex, and transporting of the protein to the core complex for degradation [159]. Several proteins work together to form a lid and a base of the regulatory complex. The core $20 \mathrm{~S}$ complex is a barrel-shaped cylindrical structure formed by four stacks of heptameric rings of $\alpha(1-7)$ and $\beta$ (1-7) subunits [160]. The rings formed by $\alpha$-subunits are located on the outer side of the proteasome as a gate for the core complex. While the inner rings of heptameric $\beta$-subunits are the proteolytic site, $\beta 1, \beta 2$, and $\beta 5$ have caspase-like, trypsin-like, and chymotrypsin-like proteolytic properties, respectively [161]. The proteasomal protein quality control is an essential process and requires high energy for the assembly of proteasomal subunits. The expression of the proteasomal subunits are tightly regulated by the transcription factor regulatory particle non-ATPase (Rpn4p in yeast), which recognizes a specific nonameric sequence (5'-GGTGGCAAA), also referred to as a proteasomal-associated control element (PACE), present in the promoter region of the majority of the genes encoding subunits of proteasome [162]. Importantly, it has been reported that nuclear translocation of Rpn4 has been found to be associated with activation of other transcription factors, including Hsf1p, yeast AP-1 (Yap1p), and pleotropic drug resistance (Pdr1p) [163].

Table 4. Proteins of the yeast proteasome conserved in humans and their functions in yeast.

\begin{tabular}{|c|c|c|c|}
\hline Yeast Protein & Human Homolog & Functions of Yeast Proteins & Ref \\
\hline \multicolumn{4}{|c|}{ Deubiquitinating enzymes (DUBs) } \\
\hline Ubp1 & USP19 & $\begin{array}{l}\text { Ubiquitin specific protease-carboxy terminal hydrolase } \\
\text { activity }\end{array}$ & [164] \\
\hline Ubp2 & USP28 & $\begin{array}{l}\text { Ubiquitin specific protease-deubiquitinates proteins, controls } \\
\text { K63 during oxidative stress }\end{array}$ & [76] \\
\hline Ubp3 & USP10 & $\begin{array}{l}\text { Regulate transport between ER and Golgi; regulates osmotic } \\
\text { stress response; deubiquitinates COPI and COPII proteins; } \\
\text { increases protein during DNA stress }\end{array}$ & {$[165-167]$} \\
\hline Ubp4/Ubp5 & USP8 & $\begin{array}{l}\text { Deubiquitinates proteins inside endosomes that are bound to } \\
\text { be delivered to vacuole for degradation; increases intracellular } \\
\text { free ubiquitin. }\end{array}$ & {$[168,169]$} \\
\hline Ubp6 & USP14 & $\begin{array}{l}\text { Negatively regulates branched polyubiquitinated proteins } \\
\text { from proteasomal degradation }\end{array}$ & [170] \\
\hline
\end{tabular}


Table 4. Cont.

\begin{tabular}{cccc}
\hline Yeast Protein & Human Homolog & Functions of Yeast Proteins & Ref \\
\hline Ubp7/Ubp11 & USP21 & Deubiquitinating proteins involved in cell cycle progression & {$[171]$} \\
\hline Ubp8 & USP22 & SAGA-mediated histone 2B ubiquitination & {$[172]$} \\
\hline Ubp9/Ubp13 & USP46 & Deubiquitinating ubiquitin-protein fusions & {$[129]$} \\
\hline Ubp10 & USP20 & Ribosome biogenesis and rRNA formation; deubiquitinates & {$[173]$} \\
\hline Sbp12 & USP15 & Deveral cellular proteins. & {$[174]$} \\
\hline Ubp14 & USP5 & Regulates gluconeogenesis & {$[106]$} \\
\hline Ubp15 & USP7 & Peroxisome biogenesis and cell cycle progression & {$[175,176]$} \\
\hline Ubp16 & USP16 & Mitochondria associated deubiquitinating enzyme & {$[177]$} \\
\hline Rpn11 & PSMD14 & $\begin{array}{c}\text { Metalloprotease present in 26S proteasome; helps in } \\
\text { deubiquitylation and proteolytic cleavage of substrates }\end{array}$ & {$[178,179]$} \\
\hline Otu1 & YOD1 & Deubiquitylation of proteins ubiquitinated by Ufd2 & {$[180]$} \\
\hline Otu2 & OTUD6B & Increases abundance of protein during DNA stress & {$[79]$} \\
\hline \multirow{2}{*}{ Yuh1 } & UCHL3 & Hydrolyses C-terminal of ubiquitin peptide bonds and release & {$[181]$} \\
\hline
\end{tabular}

\begin{tabular}{|c|c|c|c|}
\hline \multicolumn{4}{|c|}{ Proteasomal Core (20S subunit) } \\
\hline \multicolumn{4}{|c|}{$\alpha$-subunit ( $\alpha 1-7)$} \\
\hline Scl1 & PSMA6 & $\begin{array}{c}\text { Essential for survival, alpha- } 1 \text { subunit of } 20 \mathrm{~S} \text { core machinery, } \\
\text { degradation of protein substrates }\end{array}$ & [182] \\
\hline Pre8 & PSMA2 & Alpha-2 subunit of $20 \mathrm{~S}$ proteasome & [183] \\
\hline Pre9 & PSMA4 & Alpha-3 subunit of $20 \mathrm{~S}$ proteasome & [182] \\
\hline Pre6 & PSMA7 & Alpha-4 subunit of $20 \mathrm{~S}$ proteasome & [183] \\
\hline Pup2 & PSMA5 & Alpha- 5 subunit of $20 \mathrm{~S}$ proteasome & [184] \\
\hline Pre5 & PSMA1 & Alpha-6 subunit of $20 \mathrm{~S}$ proteasome & [183] \\
\hline Pre10 & PSMA3 & Alpha-7 subunit of $20 \mathrm{~S}$ proteasome & [79] \\
\hline \multicolumn{4}{|c|}{$\beta$-subunit ( $\beta 1-7)$} \\
\hline Pre3 & PSMB6 & Beta-1 subunit of $20 \mathrm{~S}$ proteasome & [182] \\
\hline Pup1 & PSMB7 & Beta- 2 subunit of $20 S$ proteasome & [185] \\
\hline Pup3 & PSMB3 & Beta-3 subunit of $20 \mathrm{~S}$ proteasome & [186] \\
\hline Pre1 & PSMB2 & Beta-4 subunit of $20 \mathrm{~S}$ proteasome & [182] \\
\hline Pre2 & PSMB5 & Beta- 5 subunit of $20 S$ proteasome & [182] \\
\hline Pre7 & PSMB1 & Beta- 6 subunit of $20 \mathrm{~S}$ proteasome & [182] \\
\hline Pre4 & PSMB4 & Beta-7 subunit of $20 \mathrm{~S}$ proteasome & [185] \\
\hline \multicolumn{4}{|c|}{ Regulatory Particle (19S subunit) } \\
\hline \multicolumn{4}{|l|}{ RP base } \\
\hline Rpt1 & PSMC2 & ATPase of 19S RP & [187] \\
\hline Rpt2 & PSMC1 & ATPase of 19S RP & [188] \\
\hline Rpt3 & PSMC4 & ATPase of 19S RP & [188] \\
\hline Rpt4 & PSMC6 & ATPase of 19S RP; spindle pole duplication; ERAD & {$[188,189]$} \\
\hline Rpt5 & PSMC3 & ATPase of 19S RP & [190] \\
\hline Rpt6 & PSMC5 & ATPase of 19S RP & [79] \\
\hline Rpn1 & PSMD2 & $\begin{array}{l}\text { Protein-protein interaction; proteasomal ligand recognition } \\
\text { and non-ATPase subunit of 19S RP }\end{array}$ & [191] \\
\hline Rpn2 & PSMD1 & Non-ATPase subunit of 19S RP & [79] \\
\hline Rpn13 & ADRM1 & Ubiquitin receptor of proteasome & [192] \\
\hline Rpn10 & PSMD4 & $\begin{array}{l}\text { Assembly of regulatory particle; non-ATPase subunit of } \\
19 \mathrm{~S} \text { RP }\end{array}$ & [193] \\
\hline
\end{tabular}


Table 4. Cont

\begin{tabular}{cccc}
\hline Yeast Protein & Human Homolog & Functions of Yeast Proteins & Ref \\
\hline RP Lid & & & {$[194]$} \\
\hline Rpn3 & PSMD3 & Essential non-ATPase subunit of 19S RP lid & {$[188]$} \\
\hline Rpn5 & PSMD12 & Essential non-ATPase subunit of 19S RP lid & {$[195]$} \\
\hline Rpn6 & PSMD11 & Essential non-ATPase subunit of 19S RP lid; assembly and \\
activity of proteasome & {$[188]$} \\
\hline Rpn7 & PSMD6 & Essential non-ATPase subunit of 19S RP lid & {$[188]$} \\
\hline Rpn8 & PSMD7 & Essential non-ATPase subunit of 19S RP lid & {$[178]$} \\
\hline Rpn11 & PSMD14 & $\begin{array}{c}\text { Essential non-ATPase subunit of 19S RP lid, degradation and } \\
\text { deubiquitylation of substrate proteins, mitochondrial and } \\
\text { peroxisomal fission. }\end{array}$ & {$[61]$} \\
\hline Rpn12 & PSMD8 & Essential non-ATPase subunit of 19S RP lid & \\
\hline
\end{tabular}

\subsection{Autophagy}

Autophagy is the major process for turnover of cellular components including organelles in eukaryotes [196]. Autophagy is a process that delivers components of the cytoplasm and organelles to lysosomal compartments, depending upon the cellular survival requirements [197]. Various mechanisms of activation of autophagy exist for the sole purpose of adapting through cellular stresses. Autophagy is categorized into three groups: microautophagy, chaperone-mediated autophagy and macroautophagy [198]. Microautophagy is a process of degradation of cellular components by direct engulfment of the cytosolic components into lysosomes [199]. Chaperone-mediated autophagy is selective autophagy, where chaperones mediate the delivery of the specific cellular components or proteins that have KFERQ motifs to the lysosomal vesicles for degradation [200]. Most of the cellular components, including organelles and protein aggregates, are degraded through macroautophagy [201]. Macroautophagy is broadly categorized into selective and non-selective macroautophagy. Previously, it was thought that the autophagy is a non-selective process, but it is now becoming clear that selective autophagy also plays a significant role in targeted degradation of cytosolic components [202]. In fact, numerous specific autophagy receptors (SARs) have been identified in autophagic vesicles that help the delivery of the imbedded cargo to the lysosomal/vacuole compartment [203]. Non-selective autophagy is a bulk degradation process and regarded as the most essential process required for cellular component turnover. Regardless of the type of autophagy and its purpose in a eukaryotic cell, 19 core autophagy related (Atg) proteins have been identified to take part in formation of autophagic vesicles [204]. Interestingly, most of these core Atg proteins are conserved from yeast to humans (Table 5). In fact, it was primarily the yeast studies that have unraveled the majority of molecular processes involved in human autophagy.

Table 5. Conservation of core autophagy related proteins and autophagy regulators from yeast to humans.

\begin{tabular}{cccc}
\hline $\begin{array}{c}\text { Proteins Involved in } \\
\text { Yeast Autophagy }\end{array}$ & Human Homologs & Function & Ref \\
\hline Sir2 & SIRT1 & $\begin{array}{l}\text { Sirtuin family NAD }{ }^{+} \text {-dependent histone deacetylase that } \\
\text { activates upstream kinases that activate Snf1/AMPK and } \\
\text { activates TFEB and autophagy in mammalian system. }\end{array}$ & {$[205,206]$} \\
\hline Tos3, Sak1, Elm1 & LKB1, CAMKK & Upstream protein kinases that activates AMPK/Snf1 & {$[207,208]$} \\
\hline Hcm1 & FOXO3 & $\begin{array}{l}\text { Expression of other fork head box transcription factor } \\
\text { proteins and expression of various proteins involved in } \\
\text { autophagy; nuclear localization and expression of target } \\
\text { genes essential for vacuolar acidification; mitochondrial } \\
\text { biogenesis and stress resistance }\end{array}$ & {$[209-211]$} \\
\hline Fkh1, Fkh2 & FOXM & $\begin{array}{c}\text { Expression required for stress resistance, autophagy, and } \\
\text { cell cycle progression }\end{array}$ & {$[212,213]$} \\
\hline
\end{tabular}


Table 5. Cont.

\begin{tabular}{|c|c|c|c|}
\hline $\begin{array}{l}\text { Proteins Involved in } \\
\text { Yeast Autophagy }\end{array}$ & Human Homologs & Function & Ref \\
\hline Sch9 & AKT/PKB & $\begin{array}{l}\text { Regulates autophagy negatively works together with } \\
\text { TORC1 }\end{array}$ & {$[214,215]$} \\
\hline Tsc1, Tsc2 & TSC1, TSC2 & Inhibits TORC1 activity and activates autophagy & [216] \\
\hline Rhb1 & Rheb & Promotes TORC1 activity and inhibits autophagy & [217] \\
\hline Snf1 & AMPK & $\begin{array}{l}\text { Activates Atg1; nutrient sensing; inactivates TORC1 } \\
\text { complex and positively regulate autophagy }\end{array}$ & {$[208,218]$} \\
\hline Torc1 & TORC1 & $\begin{array}{l}\text { Blocks interaction of Atg1 and Atg13; nutrient sensing, } \\
\text { negatively regulates autophagy }\end{array}$ & [219] \\
\hline Gtr1 & RAGA, RAGB & Part of Rag GTPase complex; regulates TORC1 activity & [220] \\
\hline Gtr2 & RAGC, RAGD & Part of Rag GTPase complex; regulates TORC1 activity & [220] \\
\hline Ssk2, Ssk22 & MAP3K4/MEKK4 & MAPK kinase kinase for Hog1 & [221] \\
\hline Pbs2 & MAP2K2/MEK2 & MAPK kinase for Hog1 & [222] \\
\hline Hog1 & MAPK14/p38 & Involved in mitophagy and pexophagy & {$[223,224]$} \\
\hline Slg1/Wsc1 & WSCD2 & Important for mitophagy; stress response & {$[224,225]$} \\
\hline Pkc1 & $\begin{array}{l}\text { PRKCA, PRKCB, } \\
\text { PRKCD, PRKCE, } \\
\text { PRKCG, PRKCH, PRKCI, } \\
\text { PRKCQ }\end{array}$ & $\begin{array}{c}\text { Activation of Bck2 in turn activating Slt2 involved in } \\
\text { pexophagy and mitophagy }\end{array}$ & [224] \\
\hline Slt2 & MAPK7/ERK5 & MAPK involved in pexophagy and mitophagy & [224] \\
\hline Atg1 & ULK1, ULK2 & $\begin{array}{l}\text { Serine/threonine protein kinase activity; conjugates with } \\
\text { Atg13; autophagy initiation regulation }\end{array}$ & [226] \\
\hline Atg2 & ATG2A, ATG2B & $\begin{array}{l}\text { Conjugates with Atg18; forms Atg2-Atg18 complex; and } \\
\text { involved in autophagosome expansion }\end{array}$ & [227] \\
\hline Atg3 & ATG3 & E2-like enzyme for formation of Atg8 lipidation complex & [228] \\
\hline Atg 4 & $\begin{array}{l}\text { ATG4A, ATG4B, ATG4C, } \\
\text { ATG4D }\end{array}$ & $\begin{array}{l}\text { Cysteine protease that processes the inactive Atg- } 8 \text { at } \\
\text { carboxy terminus to give mature Atg } 8\end{array}$ & [229] \\
\hline $\operatorname{Atg} 5$ & ATG5 & Conjugates with Atg12 & [230] \\
\hline Atg6/Vps30 & BECN1 & Important part of PI3K complexes & [231] \\
\hline Atg7 & ATG7 & $\begin{array}{l}\text { E1 like enzyme involved in both Atg12-Atg5 and } \\
\text { Atg8-PE complex formation }\end{array}$ & [232] \\
\hline Atg8 & $\begin{array}{l}\text { LC3A, LC3B, LC3B2, } \\
\text { LC3C, GABARAP, } \\
\text { GATE16 }\end{array}$ & $\begin{array}{l}\text { Conjugates with PE to form lipidation complex; } \\
\text { important part of autophagosome membrane; interacts } \\
\text { with SNARE proteins to deliver the autophagosomal } \\
\text { cargo; determines the size of autophagosome }\end{array}$ & [233] \\
\hline Atg9 & ATG9 & $\begin{array}{l}\text { The only transmembrane protein of autophagosome } \\
\text { required for phagophore expansion; interacts with Atg2 } \\
\text { and regulates autophagy }\end{array}$ & [234] \\
\hline Atg10 & ATG10 & E2-like enzyme conjugating Atg5-Atg12 & [235] \\
\hline Atg12 & ATG12 & $\begin{array}{l}\text { Forms Atg5-Atg12 complex involved in phagophore } \\
\text { expansion }\end{array}$ & [230] \\
\hline Atg13 & ATG13 & $\begin{array}{l}\text { Activated by dephosphorylation during starvation, } \\
\text { conjugates with Atg1 to initiate formation of } \\
\text { phagophore assembly site }\end{array}$ & [236] \\
\hline Atg14 & ATG14 & PI3K complex I component & [237] \\
\hline Atg17 & FIP200/RB1CC1 & $\begin{array}{l}\text { Atg1 kinase complex component involved in initiation of } \\
\text { autophagy }\end{array}$ & [236] \\
\hline $\operatorname{Atg} 18$ & WIPI1, WIPI2 & $\begin{array}{l}\text { Conjugates with Atg2; forms Atg2-Atg18 complex; binds } \\
\text { with PI3P; and involved in elongation of phagophore. }\end{array}$ & [238] \\
\hline Vps15 & PIK3R4/VPS15/p150 & Protein kinase required for activation of Vps34 & [239] \\
\hline Vps34 & PIK3C3/VPS34 & PI3K catalytic component & [240] \\
\hline
\end{tabular}




\subsubsection{Core Autophagy Machinery in Yeast}

The core autophagy proteins can be categorized in five complex modules based on their function during autophagosome formation [204]. Autophagy has been characterized by distinct stages, starting from the phagophore assembly site (PAS), where it recruits several proteins to form double membrane phagophores, to the delivery of the embedded cargo to the lysosome/vacuole (Figure 5). The autophagy related 1 (Atg1) kinase complex involving five Atg proteins (Atg1, Atg13, Atg17, Atg29, and Atg31) assembles at PAS upon activation, initiating the autophagy [226]. During starvation or rapamycin treatment, the target of rapamycin complex 1 (TORC1) gets inactivated, and Atg13, a phosphorylation substrate of TORC1, gets dephosphorylated [241]. The dephosphorylated Atg13 conjugates with Atg17 and associates with Atg1, which helps to form the pentameric Atg1 complex (Atg1-Atg13-Atg17-Atg29-Atg31 complex) [242]. The Atg1 kinase complex recruits other proteins at the PAS, including Atg9, for initiation of the expansion of double membrane phagophore [243]. The expansion of the phagophore at this point requires phosphatidyl inositol-3 kinase (PI3K) complex I activity generating required phosphatidyl inositol-3 phosphate (PI3P). PI3P is essential for elongation of the phagophore by recruiting the Atg2-Atg18 ubiquitin-like conjugation complex, Atg8-lipidation complex, and Atg5-Atg12 conjugation complex [244]. In yeast, Atg8 has been found to be the most important autophagy-associated marker. Atg8 is produced in yeast as a precursor, which is processed by a cysteine protease Atg4 and ubiquitin-like modification system involving E1 enzyme like Atg7 and E2 enzyme-like Atg3, respectively [245]. This processing of Atg8 leads to the formation of the Atg8 lipidation complex comprising the Atg8 protein and phosphatidyl ethanolamine complex. Similarly, Atg12 also gets modified by two enzymes, E1 enzyme Atg7 and E2 enzyme Atg10, before conjugating with Atg5, forming the complex [246]. The phagophore expansion leads to engulfment of the autophagy cargo, including organelles, protein aggregates, lipids, and other unwanted cellular contents depending upon the cellular requirement and ultimately forms a double membrane autophagosomes [247]. The autophagosomes containing cellular cargo then get delivered to the lysosome in mammalian cells or the vacuole in yeast for degradation and recycling.

The lysosome and vacuole provide similar acidic environments, conserved proteases, nucleases, lipases, and other hydrolytic enzymes for degradation of the autolysosomal cargo [248]. The delivery of unwanted cytosolic components into the vacuole generally takes place through multiple processes including autophagosomes (Figure 6) [249]. The fusion of the autophagosomes and lysosome/vacuole occurs with the help of tethering proteins mediating the binding of Atg8 in the autophagosome membrane and soluble N-ethylmaleimide-sensitive fusion attachment protein receptor (SNARE) complex present in lysosomal membrane [250]. The degradation of the lysosome/vacuole delivered cargo is dependent on the $\mathrm{pH}$ of the lysosome/vacuole. The acidic environment favors the activity of lysosome/vacuole resident enzymes, whereas alkalization leads to the impairment of clearance of cargo [251]. The $\mathrm{pH}$ inside the vacuole/lysosome is regulated by the vacuolar ATPase (V-ATPase) transmembrane proton pump present in the vacuole/lysosome, and also present on other intracellular organelles including the ER and Golgi complexes [252]. These proton pumps maintain the acidity of the organelle by pumping the protons in the luminal part in an energy dependent manner, while its impairment has been found to increase the $\mathrm{pH}$ of the organelle [253]. Ageing in yeast has been found to be a major contributor of vacuolar alkalization, which is found to be caused by defective assembly of V-ATPases in lysosomal membranes [210]. 


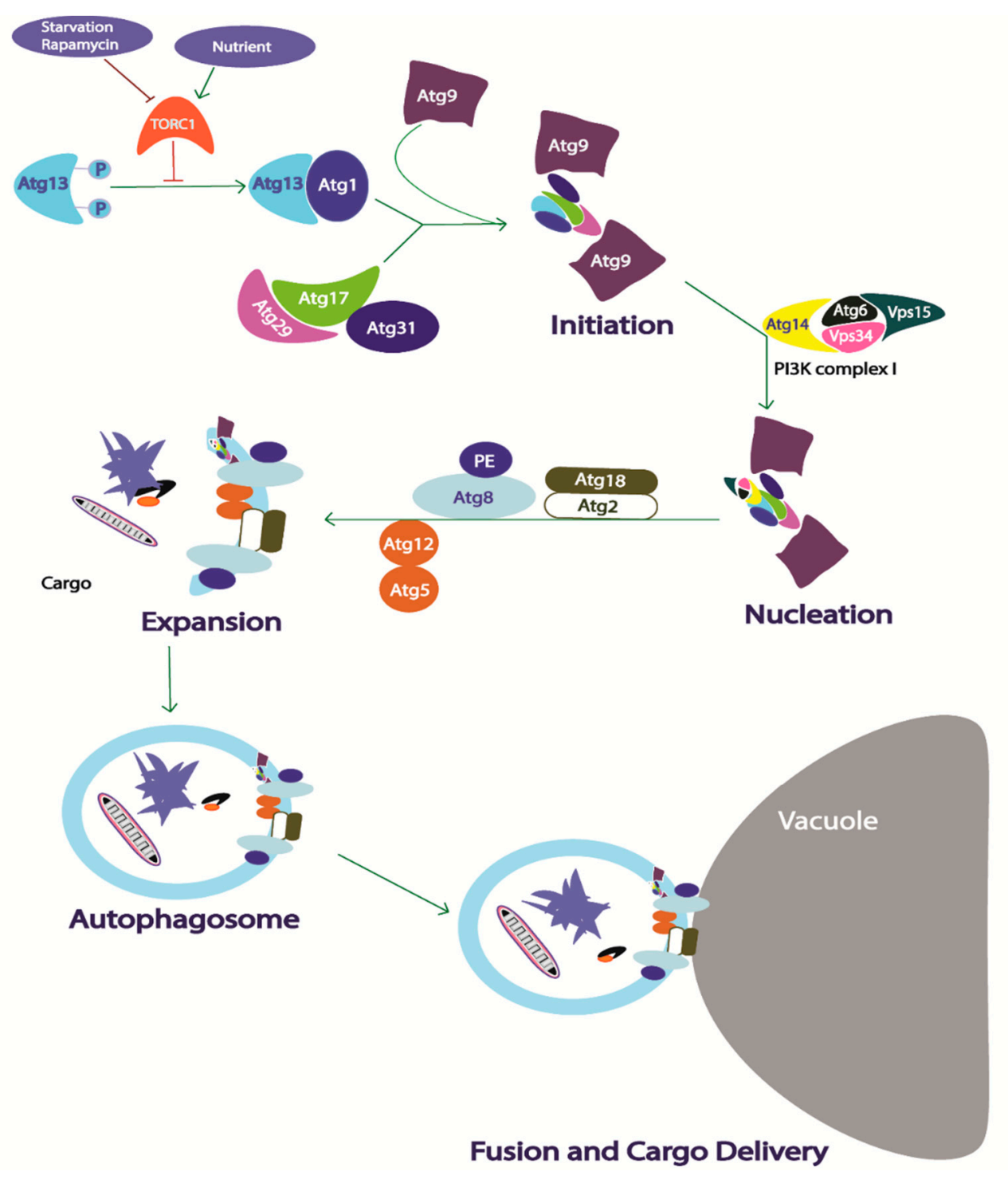

Figure 5. Schematic diagram of autophagosome formation and delivery of embedded cargo to the vacuole. Arrow, activates; Blunt arrow, blocks/inhibits; Atg, autophagy related; PI3K, phosphatidyl inositol 3 kinase; PE, phosphatidylethanolamine. Autophagosome formation is completed in four steps starting from the activation of Atg13 and formation of Atg1 kinase complex at the pre-phagosome assembly site. The second step involves the initiation of the phagophore formation by recruiting Atg9 protein. The phagophore nucleation occurs following Atg9 conjugation, where complexation with phosphatidyl inositol 3 kinase complex I occurs. The expansion of the double walled phagophore occurs embedding the cytosolic cargo that will ultimately give rise to autophagosome. The mature autophagosome then delivers the embedded cargo to the vacuole for degradation. 


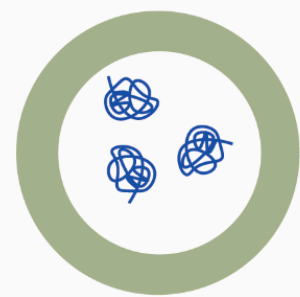

Endosomes
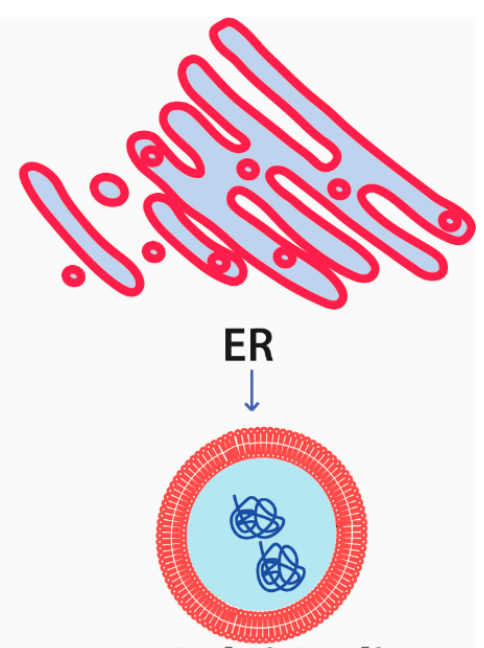

\section{Autophagosome}

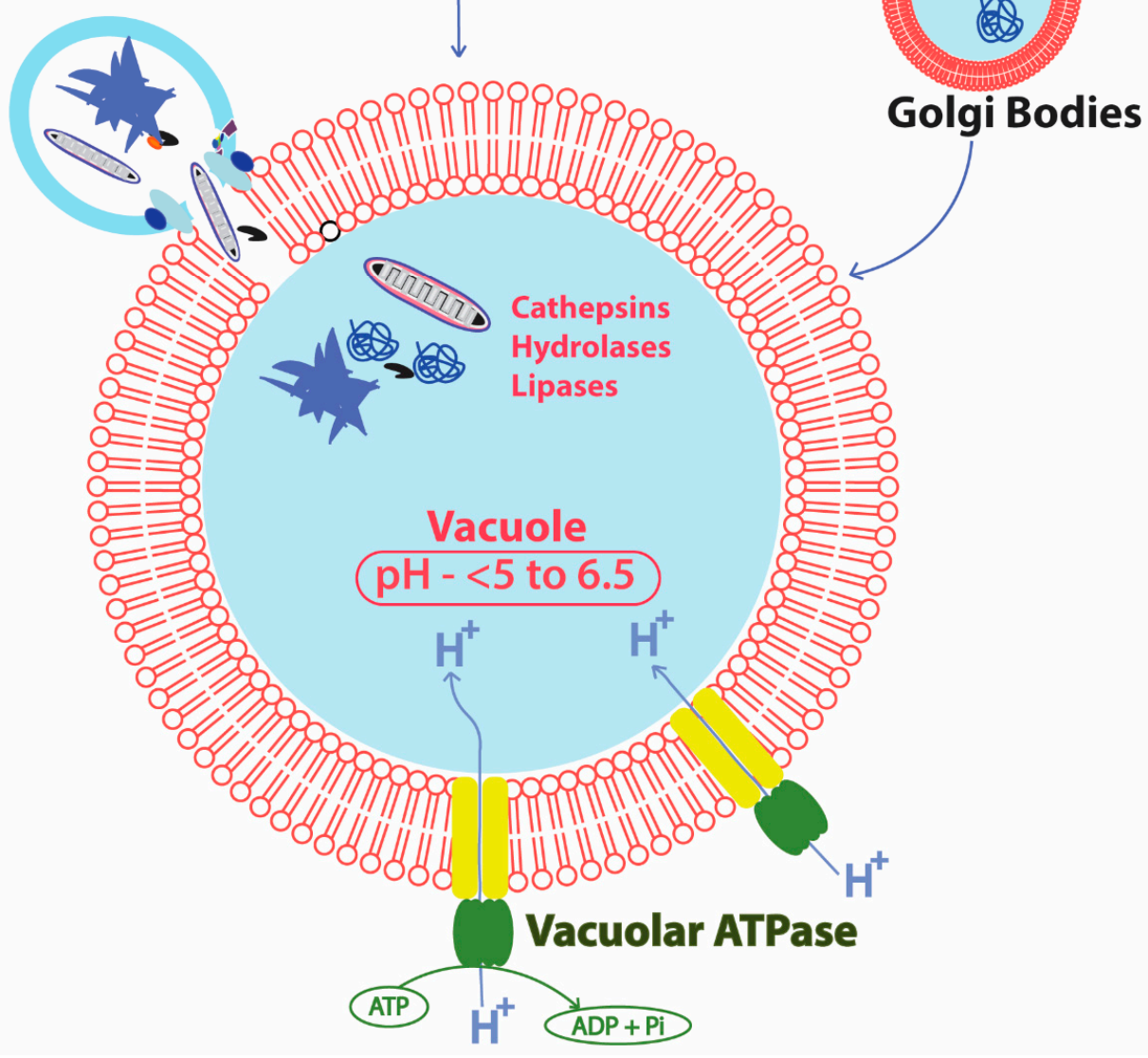

Figure 6. Different routes of delivery of cytosolic materials into the vacuole of yeast highlighting the fusion of autophagosomes with vacuole and energy-dependent role of V-ATPase in maintaining the $\mathrm{pH}$ of vacuoles. In the figure, the fusion of the autophagosome and the lysosomal membrane releases the autophagosomal cargo to the acidic lumen of the vacuole in yeast where these cargoes are degraded with the help of vacuole resident $\mathrm{pH}$ dependent cathepsins, hydrolases, and lipases. The $\mathrm{pH}$ of the vacuolar lumen is tightly regulated by an ATP dependent proton pump, the V-ATPase. Apart from the autophagosome mediated delivery of cargo inside vacuoles, endocytic vesicles and Golgi bodies carrying defective proteins are also delivered to the vacuole for degradation. Lysosomes may also degrade proteins and help protein turnover by direct engulfment of some cytosolic proteins, the process referred to as microautophagy.

Interestingly, the components of the V-ATPase and regulation of its reversible assembly are also conserved in yeast (Table 6) [254]. The V-ATPase proton pump has been divided into two major subunits, namely V0 and V1 subunits. The V1 subunit is involved in hydrolysis of ATP and the V0 part is important for the proton pump activity, which maintains the $\mathrm{pH}$ of the intracellular organelles [252]. 
Both the subunits V0 and V1 comprise of multiple subunit proteins. The reversible assembly of the V0 and $\mathrm{V} 1$ has been found to be crucial for regulation of vacuole/lysosomal cargo degradation, which has been implicated in $\mathrm{pH}$ homeostasis and longevity [255].

Table 6. Proteins of the V-ATPase proton pump conserved from yeast to humans and their function in yeast.

\begin{tabular}{|c|c|c|c|c|}
\hline $\begin{array}{l}\text { Vacuolar ATPase } \\
\text { Subunits }\end{array}$ & Yeast Proteins & Human Homologs & Function of the Yeast Protein & Ref \\
\hline \multicolumn{5}{|l|}{ V1 Subunit } \\
\hline A & Vma1 & ATP6V1A & $\begin{array}{l}\text { Site specific endonuclease activity; } \\
\text { methionine restriction regulation of } \\
\text { life span; stress response }\end{array}$ & {$[256,257]$} \\
\hline B & Vma2 & $\begin{array}{l}\text { ATP6V1B1, } \\
\text { ATP6V1B2 }\end{array}$ & $\begin{array}{l}\text { Proton pump of endomembrane; } \\
\text { protein abundance during DNA } \\
\text { replication stress }\end{array}$ & {$[79,258]$} \\
\hline $\mathrm{C}$ & Vma5 & $\begin{array}{l}\text { ATP6V1C1, } \\
\text { ATP6V1C2 }\end{array}$ & $\begin{array}{c}\text { Part of proton pump; required for } \\
\text { assembly of V-ATPase subunits at } \\
\text { vacuolar membrane }\end{array}$ & [259] \\
\hline $\mathrm{D}$ & Vma8 & ATP6V1D & $\begin{array}{c}\text { Role in proton pumping and ATP } \\
\text { hydrolysis }\end{array}$ & {$[260,261]$} \\
\hline $\mathrm{E}$ & Vma4 & $\begin{array}{l}\text { ATP6V1E1, } \\
\text { ATP6V1E2 }\end{array}$ & $\begin{array}{l}\text { Part of V-ATPase; protein content } \\
\text { increases during DNA replication } \\
\text { stress }\end{array}$ & {$[79,262]$} \\
\hline $\mathrm{F}$ & Vma7 & ATP6V1F & $\begin{array}{l}\text { Part of proton pump; required for } \\
\text { V-ATPase subunits assembly at } \\
\text { vacuolar membrane }\end{array}$ & {$[258,263]$} \\
\hline G & Vma10 & $\begin{array}{l}\text { ATP6V1G1, } \\
\text { ATP6V1G2, } \\
\text { ATP6V1G3 }\end{array}$ & $\begin{array}{l}\text { Part of proton pump and role in } \\
\text { vacuole acidification }\end{array}$ & [264] \\
\hline $\mathrm{H}$ & Vma13 & ATP6V1H & $\begin{array}{l}\text { Part of proton pump; activates and } \\
\text { stabilizes v-ATPase }\end{array}$ & {$[258,265]$} \\
\hline \multicolumn{5}{|l|}{ V0 Subunit } \\
\hline a & Vph1, Stv1 & $\begin{array}{l}\text { ATP6V0A1, } \\
\text { ATP6V0A2, } \\
\text { ATP6V0A3, } \\
\text { ATP6V0A4 }\end{array}$ & $\begin{array}{l}\text { Part of V-ATPase complex; regulates } \\
\text { V-ATPase activity; present in vacuoles, } \\
\text { Golgi bodies and endosomes }\end{array}$ & [266-268] \\
\hline c & Vma3 & ATP6V0C & $\begin{array}{c}\text { Proteolipid subunit; Vacuole } \\
\text { acidification; Copper and Iron } \\
\text { homeostasis }\end{array}$ & {$[269,270]$} \\
\hline$c^{\prime}$ & Vma11 & $\begin{array}{l}\text { ATP6V0B, } \\
\text { ATP6V0C }\end{array}$ & $\begin{array}{l}\text { Integral hydrophobic membrane } \\
\text { proteolipid; required for proton pump }\end{array}$ & {$[271,272]$} \\
\hline$c^{\prime \prime}$ & Vma16 & $\begin{array}{l}\text { ATP6V0B, } \\
\text { ATP6V0C }\end{array}$ & Part of V-ATPase & [271] \\
\hline $\mathrm{d}$ & Vma6 & $\begin{array}{l}\text { ATP6V0D1, } \\
\text { ATP6V0D2 }\end{array}$ & $\begin{array}{l}\text { Part of proton pump; required for V1 } \\
\text { assembly at vacuole membrane }\end{array}$ & {$[273,274]$} \\
\hline e & Vma9 & - & $\begin{array}{l}\text { V0 biogenesis; vacuole acidification; } \\
\text { part of V0 subunit. }\end{array}$ & [275] \\
\hline
\end{tabular}

\subsubsection{Conservation of Autophagy Regulation in Yeast Models}

In addition to the conservation of molecular machinery for protein turnover from yeast to humans, the mode of regulation is also conserved. Several molecular events, organelles, and external factors play important roles in regulating autophagy at different levels (Figure 7). The crosstalk between nutrient availability, mitochondria, protein folding mechanisms, and lysosomes is a major regulator of autophagy [276,277]. The protein folding occurs mainly in the ER and cytoplasm of a eukaryotic cell. In normal conditions, protein folding in the cytoplasm is carried out with the help of chaperones, 
especially heat shock proteins (HSPs) of the HSP70 family [29]. Any aberrations in protein folding will trigger a heat shock response through activation of heat shock factor 1 (HSF1), which enhances expression of chaperones for repairing the folding and promotes activation of autophagy for clearance of the unfolded or misfolded proteins [278].

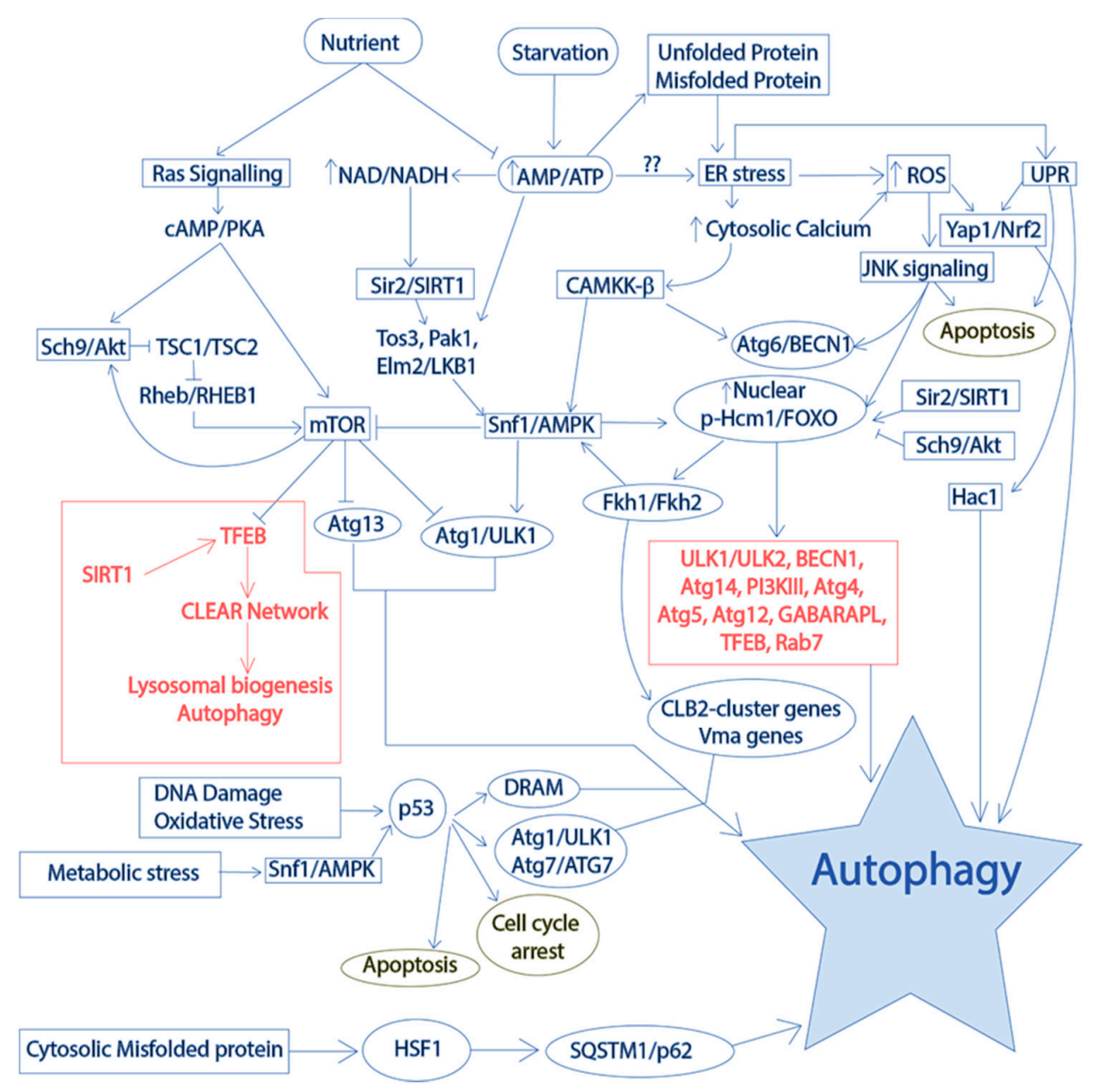

Figure 7. Some possible cell pathways that converge to yeast autophagy in response to various stimuli, including nutrient sensing, calcium homeostasis, oxidative stress, misfolded proteins, and UPR. Nutrient supplementation in a eukaryotic cell activates RAS signaling activating protein kinase activity leading to the activation of mTOR, whereas nutrient deficiency activates AMPK/Snf1 via sensing AMP/ATP ratio changes. Sir2/SIRT1 gets activated by increasing NAD ${ }^{+}$in an energy-deficient environment and activates several downstream targets via deacetylation of its targets. Nutrient starvation may also have role in inefficient protein folding triggering the formation of unfolded proteins and misfolded proteins. The folding aberrations in ER are indicated by altered calcium levels in the cytosol and ER lumen. The increase in cytosolic calcium activates CAMKK $\beta$, an upstream kinase of AMPK. The calcium abundance may also cause calcium overloading of mitochondria and enhance ROS formation. The presence of unfolded protein activates UPR, antioxidant response, MAPK signaling, and FOXO signaling and supports autophagy induction. However, chronic ER stress and JNK signaling may trigger apoptosis activation. The interaction between AMPK/Snf1, FOXO/Hcm1, and SIRT1/Sir2 induces autophagy and cytoprotective processes, whereas activation of mTOR, chronic ER stress, mitochondrial calcium overloading, and ROS may decrease survival possibly via inhibiting autophagy. During metabolic stress, DNA damage and oxidative damage, autophagy may also be activated via p53 activation. Meanwhile, p53 may also trigger apoptosis and cell cycle arrest depending on the cellular environment. Regulation of autophagy is a complex interaction of intracellular cues acting at several different levels. Some mechanisms depicted in the figure in the red boxes are not reported to be present in yeast. 
Initially, it was found that the activation of autophagy initiates from starvation and it shuts off in nutrient rich conditions [279]. It has been found that sucrose non-fermenting 1 (Snf1)/adenosine monophosphate kinase (AMPK) becomes activated with the decrease in cellular energy or ATP to AMP ratio. The activated Snf1/AMPK phosphorylates ATG1 in yeast and Unc-51-like autophagy activating kinase (ULK1), triggering the initiation of autophagic phagophore formation [280]. The activation of AMPK requires activation of upstream kinases activity mediated by sirtuin (SIRT1/Sir2), the NAD ${ }^{+}$ dependent histone deacetylase [281,282]. SIRT1/Sir2 regulates activity of multiple substrates inside cell apart from histones. The activity of SIRT1/Sir2 is important for cell survival, life span, and longevity [283]. In addition, the energy depletion in a cell not only reduces the AMP/ATP ratio, but also converts more NADH to $\mathrm{NAD}^{+}$to generate energy through the electron transport chain [284]. The cellular environment with a higher level of $\mathrm{NAD}^{+}$activates SIRT1 expression and SIRT1-mediated deacetylation of its targets [285]. In mammals, another important target of SIRT1 is transcription factor EB (TFEB), the master regulator of lysosome biogenesis and autophagy [2]. In addition, DNA damage, metabolic stress, and oxidative damage of cells activates tumor suppressor protein p53 mediated activation of autophagy and cell cycle arrest [286]. It has been reported that activation of p53 during metabolic stress also requires AMPK mediated phosphorylation [287]. The p53-dependent cytoprotective function is dependent on its nuclear translocation, while cytosolic localization of the protein has been found to trigger apoptosis and cell death. The acetylation of p53 has been found to be associated with apoptosis activation [288]. Hence, Sir2/SIRT1 mediated deacetylation of p53 may have cytoprotective role as p53 is also a known substrate for Sir2/SIRT1 [289]. However, chronic cellular damage to the cell is the major reason for the apoptosis activation and cell death via p53 acetylation.

The mitochondrial electron transport chain is the primary source of intracellular reactive oxygen species [290]. Additionally, the mitochondria also serve as the major source of iron-sulfur clusters, heme, and phospholipids that are important for normal cell function. In relation to autophagy regulation, mouse models with defective mitochondria are shown to impair the lysosomal degradation [291]. The impairment of lysosome was attributed to the enlargement of lysosome associated membrane protein 1 (LAMP1)-positive lysosomal vesicles and the elevation of $\mathrm{pH}$ in the lysosome causing defective hydrolytic activity [292]. The mitochondrial dysfunction mediated acute impairment of lysosome triggers lysosomal regeneration or biogenesis through activation of TFEB [293]. The TFEB activation changes its subcellular localization from cytosol to nucleus and enhances its binding to the target genes. However, another transcription factor zinc finger with KRAB and SCAN domains 3 (ZKSCAN3) finely tunes expression of TFEB target genes by restricting TFEB-DNA binding by recognizing similar promoter regions [294]. In nutrient deficient conditions, ZKSCAN3 translocates to the cytoplasm and TFEB to nucleus. In chronic mitochondrial stress, the impairment of lysosomes is not replenished by lysosomal biogenesis. This could be due to irreversible cell damage caused by impairment of mitochondrial turnover or mitophagy.

On the other hand, the presence of nutrients in the cellular environment activates TOR complex (TORC), which prevents conjugation of Atg1p and Atg13p [241]. The nutrient availability has also been found to activate Ras signaling in both yeast and mammals [295-297]. In mammals, Ras signaling activates protein kinase B (Akt) in a cyclic AMP (cAMP)-dependent manner through adenylate cyclase activation [298]. The protein kinase B (Akt) is a serine/threonine kinase that activates TORC by deactivating tuberous sclerosis complex (TSC1 and TSC2), inhibitors of TORC [299]. Although yeast Ras signaling has not been greatly explored, the TSC complex and TORC in yeast are similar to that of mammals. The yeast TORC consists of two components TOR1 and TOR2 complex, which works in conjunction with several other proteins to have its autophagy inhibitory effect [300]. Nutrient abundance regulation of TORC plays a positive role in TOR activation, which inhibits autophagosome formation initiation. The TOR kinase activity phosphorylates several transcription factors that induce autophagy by enhancing expression of autophagy-related genes [301]. The TOR kinase activity has been reported to inhibit the Snf1/AMPK activation and downstream signaling [302]. The activated TOR can also phosphorylate TFEB rendering it inactive and limiting its nuclear translocation ultimately 
inhibiting autophagy and lysosomal biogenesis [303]. The AMPK inactivation and TOR activation subsequently downregulate autophagy, while its reversal induces autophagy. In addition, glucose abundance also increases the hexokinase II activity producing glucose-6-phosphate. The hexokinase II is also reported to inhibit TORC in glucose deficient condition, while glucose abundance spares TOR to get activated [304].

Another important cellular event that can activate autophagy is calcium ion turnover in the cytoplasm [305]. The endoplasmic reticulum harbors most of the calcium in a cell, where it plays a crucial role in energy-dependent oxidative protein folding and stability [306]. Furthermore, calcium is also present in other organelles, including lysosomes and mitochondria. The balance of the ER intraluminal concentrations of calcium depends on the energy requiring voltage-gated calcium channels [307]. Energy depletion or conditions leading to ineffective transport of calcium has an important role in protein folding and calcium homeostasis [308]. An increment in the cytoplasmic calcium concentration has been reported to increase oxidative damage [309]. Calcium overloading of mitochondria may have detrimental effects in mitochondrial function and may cause serious damage [310]. In the meantime, subtle increments in calcium levels may have important regulatory effects on autophagy activation [305]. Increased cytosolic calcium may indirectly inform protein folding aberrations. The depletion of energy in the cell may be a cause for such display, while the cytosolic calcium signals by activating $\mathrm{Ca}^{2+} /$ calmodulin dependent protein kinase kinase $\beta$ (CAMKK $\beta$ ) pathway to activate autophagy to replenish the energy deficits [311]. Both the energy depletion and protein misfolding need to be rectified for proper cell function. The CAMKK $\beta$ senses increased calcium and gets phosphorylated, which in turn activates AMPK, beclin 1 (BECN1) and induces autophagy [312-314]. The calcium ions present in lysosome/vacuole are important for regulating the $\mathrm{pH}$ of the vesicle [315]. The increased leaching of calcium from lysosomal compartment into cytosol reduces the acidity, which in turn impairs the activity of lysosome resident enzymes.

Fork head (Fkh) transcription factors are one of the major classes of autophagy regulators in almost all eukaryotic systems [316]. Although nearly 18 subfamilies of Fkh family have been reported in mammalian system, only two subfamilies are found to be conserved in yeast $[213,317]$. Homologs of mammalian fork head box (FOX) transcription factors FOXO and FOXM, namely high-copy suppressor of calmodulin $1(\mathrm{Hcm} 1)$ and $\mathrm{Fkh} 1 / \mathrm{Fkh} 2$, are found in yeast. $\mathrm{Hcm} 1$ is the master regulator of Fkh1/Fkh2 expression, while its nuclear exclusion during ageing in yeast is reported to cause vacuolar alkalization [210]. The nuclear exclusion of $\mathrm{Hcm} 1$ and associated vacuolar alkalization impairs autophagic clearance in ageing cells resulting in loss of proteostasis. The Snf1/AMPK, a major regulator of autophagy in yeast, phosphorylates Hcm1, which enhances its nuclear translocation and causes subsequent expression of target genes [209]. The expression of transcription factors Fkh1/Fkh2 through Hcm1 increase expression of their target genes, including Snf1, in a positive feedback loop inducing autophagy in yeast [318]. In a mammalian system, nuclear translocation of FOXO transcription factors have been reported to activate ULK1/ULK2, Sestrin 3 (Sesn3), beclin 1 (BECN1), PI3K, Atg14, Atg4, Atg5, Atg12, Microtubule associated protein 1 light chain 3 beta (MAP1LC3B), GABA type A receptor associated protein like 1 (GABARAPL1), TFEB and Rab7-a member of the RAS oncogene family [319-321]. The nuclear translocation of FOXOs is also dependent on SIRT1-dependent deacetylation, indicating co-expression of FOXOs with SIRT1 as very crucial for cell survival [212,322]. How yeast FOXO homologs are involved in regulating autophagy remains elusive. In a recent study, Fkh1/Fkh2 function in collaboration with Sir2 was found to be cytoprotective, while reduced activity of these transcription factors reduced cell survival [212]. In the meantime, the Akt mediated phosphorylation of FOXOs can trigger its cytosolic translocation thus inhibiting expression of autophagy-related genes [323]. Apart from autophagy regulation, Fkh1/Fkh2 expression is also important in yeast for cell cycle progression, apoptosis, stress resistance, DNA damage repair, oxidative stress, and ageing [212].

The increase in oxidative stress during ageing is a major contributor of autophagy impairment [324]. During electron transport in the mitochondrial membrane, formation of superoxide free radicals is 
normal. The loss of electrons from the electron transport chain also contributes to generation of free radicals. These free radicals are generally neutralized by various oxidative stress response proteins [325]. The level of reactive oxygen species (ROS) and reactive nitrogen species (RNS) inside cells are delicate and are balanced in subtle manner. A slight increase in ROS and RNS may be indicative of important molecular changes inside cell. However, a higher rise in oxidative stress may signify cellular damage and the requirement for an oxidative stress response and antioxidants [326]. The enhanced oxidative stress activates oxidative stress response genes by activating transcription factors nuclear factor erythroid 2-related factor 2 (NRF2) in mammals and Yap1/suppressor of kre null (Skn7) in yeast [327]. The activated antioxidant transcription factors translocate into the nucleus, where they recognize specific sequences in the promoter region, also referred to as antioxidant response elements (ARE). The binding of the transcription factors to these unique regions of promoters enhances transcription of downstream phase I, II, and III detoxifying genes and autophagy related genes [328,329]. However, an abnormal oxidative environment may also be favorable for disulfide bond formation between thiol groups of cysteine residues of several proteins, which may also lead to protein aggregation inside cell [330]. Autophagy replenishes the oxidative damage via clearance of the damaged proteins, oxidized lipids, protein aggregates, and organelles. The mitogen activated protein kinase (MAPK) signaling-mediated autophagy becomes activated during oxidative stress [331]. In eukaryotes, MAPK kinase kinase (MAPKKK), MAPK kinase (MAPKK), and MAPK are sequentially phosphorylated for signal transduction via MAPK signaling [332]. Despite its crucial role in regulating cell survival and cell death via autophagy and apoptosis, MAPK signaling is demonstrated to be involved in pexophagy and mitophagy in yeast cells [224,333]. During increased oxidative stress in a cell, c-Jun N-terminal kinases (JNK) signaling, a type of MAPK signaling, gets highly activated which in turn activates FOXOs, BECN1 mediated autophagy, and c-Jun and c-Fos transcription factors mediate expression of autophagy-related genes [334-336]. However, prolonged chronic oxidative damage in a cell may trigger apoptosis through JNK signaling [337].

Lastly, the autophagic clearance of cellular garbage is also dependent on lysosomal (in mammals) and vacuolar (in yeast) degradation [338]. The degradation in lysosomes/vacuoles is dependent on the $\mathrm{pH}$ of the organelles, which is regulated by the intracellular membrane proton pump V-ATPase [339]. It is not only the proteins involved in the formation of V-ATPase complex that are conserved from yeast to humans, the mechanisms of assembly and disassembly of the subunits of V-ATPase in the organelles are also conserved [340]. Nutrient rich conditions are found to promote the V-ATPase assembly in both yeast and mammals, perhaps involved in reducing increased hydrogen ion concentration due to excessive glycolysis which in turn balances cytosolic $\mathrm{pH}$ due to higher metabolism [255,341]. The readily available energy required for V-ATPase activity during nutrient fed conditions could be another important player in the assembly of the proton pump. In yeast, the Ras/cAMP/PKA pathway has been reported to be involved in activation of assembly of V-ATPase subunits during nutrient fed conditions [342]. Additionally, regulator of ATPase of vacuoles and endosomes (RAVE) complex also regulates assembly of V-ATPase in vacuoles of yeast [343]. Recent studies suggest a nutrient rich environment supports the V-ATPase mediated TORC1 activation via Ras homolog enriched in brain (Rheb) protein. Rheb protein is activated by phosphorylated Akt/PKB in the vacuolar/lysosomal membrane and activates anabolic processes inside cells, including inhibition of autophagy and enhancement of protein translation [344]. The lysosomal/vacuolar membrane resident Ragulator-Rag complex is crucial in regulating the TORC1 activation [345]. Conversely, the optimal nutrient supply renders the V-ATPase subunits disassembled from the intracellular membranes, inhibiting the V-ATPase activity [346]. Interestingly, it was also found that the V-ATPase assembly is also enhanced during glucose and amino acid starvation. The glucose starvation mediated assembly of V-ATPase has been found to activate AMPK through axis inhibitor (AXIN)/liver kinase B1 (LKB1) pathway [347]. Such upregulation of V-ATPase assembly in the vacuolar/lysosomal membrane could help clear the cargo within autolysosomes and replenish the free amino acids and energy required for cell survival. Additionally, AMPK activation inhibits mTORC1 activity and supports catabolic processes by activating 
autophagy. In this way, regulated reversible V-ATPase assembly and dissociation regulates cellular homeostasis by controlling the major protein quality control mechanism including autophagy.

\section{Proteostasis Failure in AD}

$\mathrm{AD}$ is characterized by the accumulation of unwanted toxic protein aggregates including tau neurofibrillary tangles and $A \beta$ aggregates (oligomers, fibrils, and senile plaques) [2]. From previous studies, it has been found that the protein quality control and the cellular defense system has failed severely during $\mathrm{AD}$ progression [348]. The impact of $\mathrm{AD}$ pathogenesis can be found at all the levels of the proteostasis network.

The increased phosphorylation of PERK and eIF2 $\alpha$, upregulation of CHOP signaling in temporal cortex, increased expression of BiP chaperones, HSP70 family proteins and increased splicing of XBP1 in temporal cortex and hippocampal tissue indicates increased UPR and chronic ER stress during AD pathology [349-351]. The activation of protein kinase activity of PERK has been demonstrated to activate Glycogen synthase kinase 3 beta (GSK3 $\beta$ ), a major contributor of tau hyperphosphorylation in AD patients, in cell culture studies [352]. These evidences in support of chronic ER stress and UPR during AD provides rationale to explore therapeutic agents that can reduce ER stress or at least reduce protein synthesis in AD patients. Another important molecular marker of chronic ER stress is calcium dyshomeostasis, which is prevalent in AD [353]. The unacceptable calcium levels in the cytoplasm may lead to calcium overloading of organelles including mitochondria in neurons inhibiting respiratory growth. Impaired mitochondrial function and increased oxidative damage due to ROS formation during AD may partly be contributed by such abnormalities in neurons of $\mathrm{AD}$ patients [354]. Additionally, ER stress is one of the major causes of RNA-protein granules in eukaryotic cells. Meanwhile, recent studies suggest an association of tauopathies with the formation of such granules, hinting at an important role of impaired UPR in tauopathies implicated in AD [355]. The UPR inside a cell is generally backed up by UPS and autophagy.

Accumulation of high levels of ubiquitinated proteins during AD pathology strongly suggests impairment in UPS system [356]. The decreased proteasome activity in various parts of brains of AD patients signifies the impairment of UPS [357]. The oxidation of deubiquitinating enzymes (DUB)-mutated ubiquitin results in its aggregation or reduced expression of E1 and E2 enzymes in AD patients' brains, which strongly implies its impairment during AD pathogenesis [358]. Under normal conditions, UPS degrades proteins that are soluble including soluble forms of $A \beta$ and tau, while the hydrophobic forms of these proteins are degraded by autophagy [359]. Meanwhile, impaired UPS mediated degradation of soluble $A \beta 40$, and microtubule associated protein tau may lead to their accumulation over time. With other molecular accomplices including activated GSK3 $\beta$ during AD progression, tau gets hyperphosphorylated and forms neurofibrillary tangles inside cells [360]. On the other hand, the presence of hydrophobic $A \beta 42$ in the neurons may seed the aggregation of soluble A $\beta 40$ [361]. In a normal cell, the impaired proteasome and ubiquitylated proteins can also be degraded through autophagy.

The impairment of autophagic clearance of aggregated proteins in AD brains may result in $\mathrm{A} \beta$ plaque formation followed by the exocytosis of amyloid aggregates or cell death [362]. The impaired UPS and autophagy defects also result in reduced clearance of tau tangles present in brains of AD patients, impairing the synapsis and cognition in patients [363]. Recent studies revealed important roles of UPS in regulating Atg9 availability, which in turn regulates autophagy progression [364]. In general, the nutrient status of a cell regulates UPS-dependent regulation of several cellular proteins and transcription factors that drive cell fate. During ageing, cells are deprived of nutrients due to their impaired nutrient sensing, which may have crucial roles in impairing the UPS system [365]. The impaired UPS in AD patients leads to the accumulation of ubiquitylated proteins, aggregation of misfolded proteins, and impairment of transcriptional regulation in ageing cells. The impaired crosstalk between the UPS and autophagy, resulting in progressive destruction of the cellular proteostasis network during ageing, seems to be the major culprit in AD pathology. 
In normal brains, the neuronal cells are highly efficient in clearing the autophagosomes as compared to other tissues of the human body [366]. However, during ageing the efficiency of autophagic clearance gradually decreases, rendering the aged neurons prone to death [367]. The accumulation of very high amounts of autophagic vesicles in dystrophic neurites of AD patients clearly supports impairment of autophagic clearance [368]. Interestingly, the various stages of autophagic vesicles present in numerous defective neurons are filled with A $\beta$ peptides, APP, and $\beta$-C-terminal fragment ( $\beta C T F)$ of the APP [362]. It has been clear that the autophagosomes are the primary site for $A \beta$ generation by $\gamma$-secretase mediated cleavage of the $\beta C T F$ [369]. The formation of $A \beta$ peptides in normal brain is accompanied by enhanced clearance by the cathepsin-mediated degradation, while AD brains are ineffective in such clearance [370]. Genetic variations in cathepsin $D$ have been found associated with higher accumulation of $A \beta$ in $A D$ patients [371]. One reason behind such observations is the alkalization of the lysosomes due to impaired V-ATPase assembly [253]. In recent years, modulation of reversible V-ATPase assembly has been a cherished topic in AD therapeutics. The soluble forms of intracellular A $\beta$ are likely to be diffused in cytosol and are degraded by the help of heat shock factor activation and subsequent expression of heat shock proteins [372]. However, reduced expression of heat shock proteins in AD pathology has been observed, suggesting one possible mechanism of impairment of protein misfolding, clearance, and accumulation of $A \beta$ peptides in dystrophic neurites $[372,373]$. The hydrophobic forms of $A \beta(A \beta 42)$ may still remain in acidic lysosomes, where the formation of oligomers and fibrils are favored [374]. In addition, as mentioned previously, familial AD has been found associated with mutations in several genes including PSEN1, the catalytic subunit of $\gamma$-secretase found in endosomes, autolysosomes, and autophagosomes [375]. The PSEN1 protein has also been found to regulate the autophagosome lysosome fusion by modulating telencephalin (TLN) clearance [376,377]. The mutated version of the PSEN1 are found ineffective in regulating telencephalin levels, resulting in ineffective fusion of the autophagosomes and lysosomes, contributing to another reason for accumulation of autophagic vesicles during AD. Apart from these, PSEN1 is involved in the calcium balance, apoptosis, synaptic plasticity, and proteolysis of several proteins, including APP and cell adhesion through its catalytic activity. In addition, $\gamma$-secretase independent activity of PSEN1 has been shown to have a role in vacuolar acidification and UPR. The mutated PSEN1 in AD might have crucial role in impairing the vacuolar protease activity by modulating the vacuolar $\mathrm{pH}$ [362]. Additionally, the mutation in PSEN1 has been reported to reduce the expression of BIP chaperones, leading to enhanced ER stress [378].

The mitochondria are reserves of iron and during mitophagy release of oxidized iron $\left(\mathrm{Fe}^{2+}\right)$ increases oxidative stress mediated by the Fenton reaction [379]. The release of oxidized iron can also occur during degradation of other iron rich molecules or proteins like ferritin. The interaction of oxidized lipids, proteins, and metals in lysosome with the free radicals may result in oxidation of the reacting molecules and their aggregation, ultimately malfunctioning of the lysosome [380]. It may result in production of auto-fluorescent ceroid particles referred to as lipofuscin, a hallmark of ageing [381]. Furthermore, excessive mitophagy due to chronic mitochondrial stress during AD may contribute to an increase in lipofuscin formation and increase oxidative damage, impairing the lysosomal degradation. In normal cells, the lipofuscins are neither degraded nor exocytosed, but can be diluted out by cell division [381]. However, terminally-differentiated neurons are unable to divide further, thus leading to accumulation of such particles in neuronal cells during ageing [382]. The lipofuscin has been reported to interact with autophagosomes, lysosomes, and proteasomes inside cells and impair the cellular protein homeostasis implicated during AD progression [383,384]. Additionally, iron overloading is a common feature of $\mathrm{AD}$ brains and is accompanied by ferroptosis-mediated cell death. Recent evidence supports the high association of autophagy-related genes in increasing the ferroptosis-mediated cell death [385]. In AD patients, events including monoamine oxidase hyperactivation, calcium dyshomeostasis, increased oxidative stress, lower expression of SIRT1, hyperactivation of CAMKK $\beta$ and MAPK signaling, defective assembly of V-ATPase, alkalization of lysosomes, defective autophagosome-lysosome fusion, and other important molecular players may render the neurons to nurture accumulation of autophagic vesicles [253,354,362,386-390]. 
In summary, the impairment of most of the mechanisms of protein synthesis, folding and quality control governs the accumulation of protein aggregates in AD patients' brain. Hence, it is of utmost importance to study the proteostasis network to understand the ways to modulate the balance of protein turnover and recover overall cellular function. This will aid the design of potential therapeutic agents.

\section{Future Perspectives of Using Yeast as a Model Organism for Alzheimer's Disease}

The power of using yeast as a model organism to study AD comes from the underlying similarity to human cells, including neurons, ease of using yeast to understand molecular processes, and the availability of analytical platforms $[15,24]$. The intriguing fact that most of the processes of ageing are also conserved in yeast makes it an appropriate model for age-related neurodegenerative diseases. S. cerevisiae cells bud asymmetrically for up to 20-25 cycles, indicating a limited replicative lifespan [16]. The division of cells produces smaller daughter cells and leaves scars on the cell surface [391]. The ability to readily track these scarred cells provides a convenient platform to study young cells and aged cells [392]. In addition, replicative ageing of a yeast cell also increases the size of the yeast, making it possible to explore yeast using size-based, cutting edge technological platforms such as single cell analyzers $[393,394]$. The development of yeast models that expresses toxic proteins of $\mathrm{AD}$, including the $\mathrm{APP}, \mathrm{A} \beta$, and tau protein in the past, has provided increasing interest among researchers $[17,19,25,395,396]$. In addition, knowledge gained from the use of unmodified yeast continues to provide answers to research questions pertaining to fundamental aspects of eukaryotic cells, which could be crucial in disease pathology. The outcomes observed in yeast after heterologous expression of such human proteins has served as the basis for further studies and unravelling of the molecular pathogenesis caused by these proteins. These yeast models have provided unique frontier for screening of both cytoprotective and cytotoxic compounds [18,21,397-399]. Several yeast reporter systems have also been developed, which aid $\mathrm{AD}$ research and provide directions for future research $[400,401]$.

The conservation of genetics, protein synthesis, processing, and quality control system of eukaryotes including the ER stress, formation of stress granules, chaperones, heat shock stress response, unfolded protein response, ubiquitin proteasome system, and autophagy advocates yeast as appropriate model for studies of disease involving proteostasis failure including AD. The data coming from yeast are consistent with observations in AD patients, and hence, can be utilized for further studies. Future studies involving complex interplay between the parts of proteostasis network can be easily accomplished in yeast models of $\mathrm{AD}$, which have potential to provide clarity in $\mathrm{AD}$ pathogenesis.

The conservation of most of the core machinery of UPS and presence of homologs of most of the counterparts of the human UPS in yeast system offers promise for the future of drug discovery studies. Additionally, most of the core autophagy related proteins and proteins involved in lysosomal degradation are also conserved in yeast. In fact, it is the yeast system that has provided enormous amount of information on these fundamental processes of a eukaryotic system. Recent studies showing high involvement of ferroptosis and iron overloading in $\mathrm{AD}$ and its association with autophagy provide important opportunities that can be addressed with yeast studies, as some of the markers of ferroptosis and autophagy-related genes are conserved in yeast. Apart from these benefits for using yeast as a model, the ability of yeast to grow with defective mitochondria provides unique platform for studies involving mitochondrial dysfunction in yeast, which is crucial for UPS, autophagy, and lysosomal functioning. In such a scenario where mitochondria are defective, yeast can be very useful for finding compounds that can rescue and enhance mitochondrial inhibition or help mitochondrial regeneration, both types of study crucial for AD research. In contrast, such studies cannot be performed in any mammalian system, as mitochondrial respiration is crucial for cell survival in mammals.

Nevertheless, differences still exist due to the complexity of higher multicellular eukaryotes as compared to the unicellular simple eukaryotic yeast. However, heterologous expression of uncommon human proteins in yeast may still interact with some conserved proteins inside yeast that could still be beneficial for understanding its role in cell and finding the interaction network that will help to 
predict the future directions. In fact, the reduced complexity in yeast cell models and the possibility of reconstitution of human proteins in controlled environment makes yeast a fascinating tool to explore role of human proteins in disease pathology. At the same time, the lack of conservation of some mechanisms including immune system, cell to cell communications, and nervous system in yeast limits its use in understanding complex processes occurring in human tissues, while the conservation of most of the cellular signaling and processes still provide rationale for using yeast as a single cell model organism to study protein homeostasis network. Considering the high association of proteostasis network and AD progression, yeast will prove to be an important tool for finding therapeutics and understanding the molecular processes of $\mathrm{AD}$ and other similar diseases.

Author Contributions: S.D. conceived, designed, and wrote the paper. I.M. conceived and supervised the paper. All authors have read and agreed to the published version of the manuscript.

Funding: This research received no external funding.

Acknowledgments: We thank RMIT University for providing the RMIT Research Stipend Scholarship and RMIT Tuition Fee Offset Scholarship awarded to Sudip Dhakal.

Conflicts of Interest: The authors declare no conflict of interest.

\section{Abbreviations}

$\begin{array}{ll}\text { AD } & \text { Alzheimer's Disease } \\ \text { A } \beta & \text { Amyloid beta } \\ \text { EOAD } & \text { Early Onset Alzheimer's Disease } \\ \text { LOAD } & \text { Late Onset Alzheimer's Disease } \\ \text { APP } & \text { Amyloid precursor protein } \\ \text { PSEN } & \text { Presenilin } \\ \text { GWAS } & \text { Genome Wide Association Studies } \\ \text { ER } & \text { Endoplasmic reticulum } \\ \text { UPR } & \text { Unfolded protein response } \\ \text { eIF2 } \alpha & \text { Eukaryotic translational initiation factor 2 alpha } \\ \text { mRNA } & \text { Messenger ribonucleic acid } \\ \text { Ire1 } & \text { Inositol requiring element 1 } \\ \text { Bip } & \text { Binding immunoglobulin protein } \\ \text { ATF } & \text { Activating transcription factor } \\ \text { CREB } & \text { cAMP response element binding } \\ \text { HAC1 } & \text { Homologous to Atf/CREB1 } \\ \text { Ypt1 } & \text { Yeast protein two 1 } \\ \text { Rlg } & \text { tRNA ligase } \\ \text { bZIP } & \text { Basic leucine zipper } \\ \text { UPRE } & \text { Unfolded protein response element } \\ \text { ERAD } & \text { Endoplasmic reticulum associated degradation } \\ \text { PERK } & \text { PKR like ER kinase } \\ \text { XBP1 } & \text { X-box binding protein 1 } \\ \text { SP1 } & \text { Specificity protein 1 } \\ \text { SP2 } & \text { Specificity protein 2 } \\ \text { CHOP } & \text { C/EBP homologous protein } \\ \text { GADD34 } & \text { Growth arrest and DNA Damage 34 } \\ \text { UPS } & \text { Ubiquitin proteasome system } \\ \text { ATP } & \text { Adenosine triphosphate } \\ \text { PACE } & \text { Proteasomal associated control element } \\ \text { Rpn } & \text { Regulatory particle non-ATPase } \\ \text { Yap1 } & \text { Yeast AP-1 } \\ \text { Pdr1 } & \text { Pleotropic drug resistance 1 } \\ \text { SAR } & \text { Autophagy related } \\ \text { Atg } & \text { a }\end{array}$




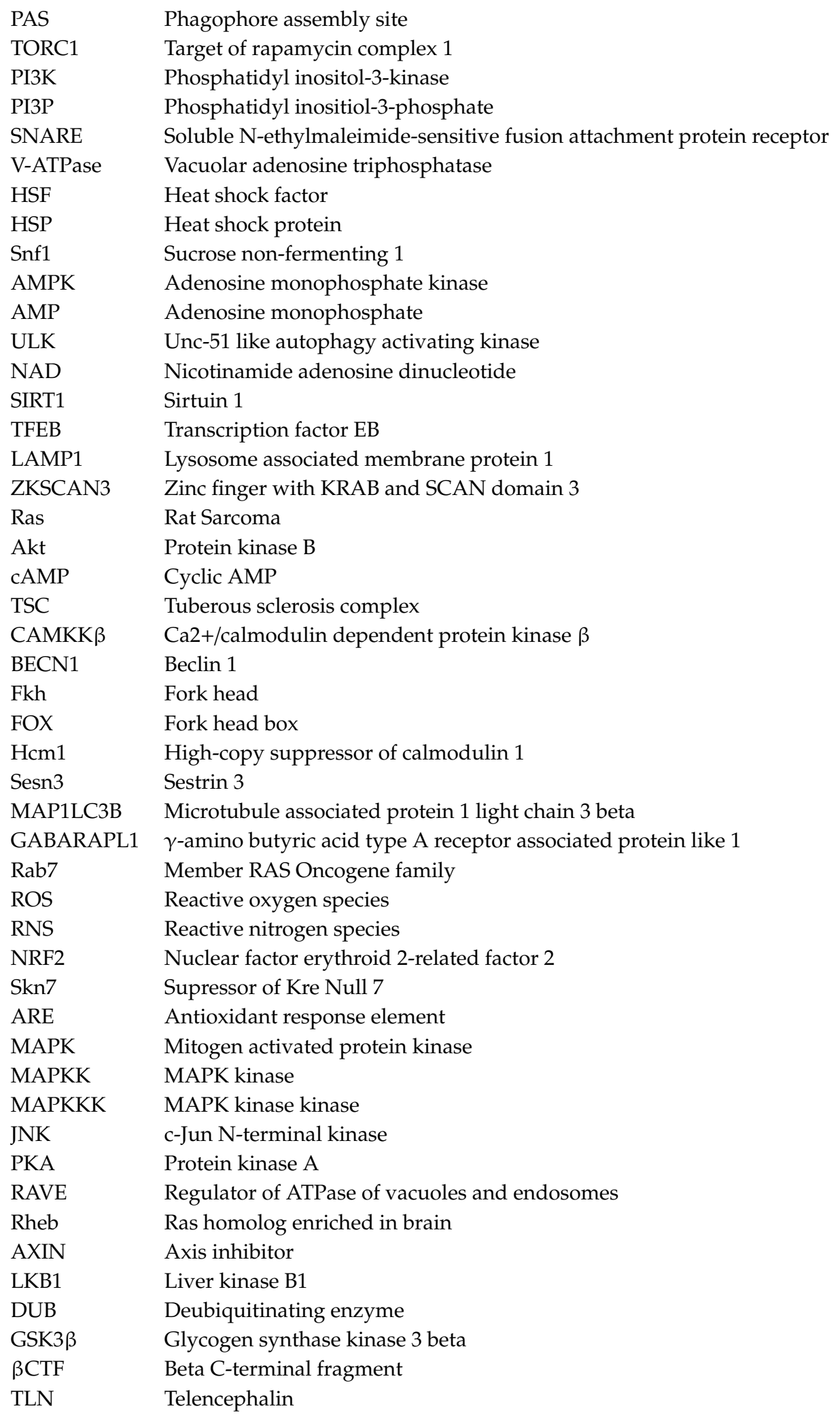

\section{References}

1. Alzheimer's Association. 2020 Alzheimer's disease facts and figures. Alzheimer's Dement. 2020, 16, 391-460. [CrossRef]

2. Dhakal, S.; Kushairi, N.; Phan, C.W.; Adhikari, B.; Sabaratnam, V.; Macreadie, I. Dietary polyphenols: A multifactorial strategy to target Alzheimer's disease. Int. J. Mol. Sci. 2019, 20, 5090. [CrossRef] 
3. Panza, F.; Lozupone, M.; Logroscino, G.; Imbimbo, B.P. A critical appraisal of amyloid- $\beta$-targeting therapies for Alzheimer disease. Nat. Rev. Neurol. 2019, 15, 73-88. [CrossRef]

4. Braak, H.; Braak, E. Neuropathological stageing of Alzheimer-related changes. Acta Neuropathol. 1991, 82, 239-259. [CrossRef] [PubMed]

5. Cuyvers, E.; Sleegers, K. Genetic variations underlying Alzheimer's disease: Evidence from genome-wide association studies and beyond. Lancet. Neurol. 2016, 15, 857-868. [CrossRef]

6. Brouwers, N.; Sleegers, K.; Van Broeckhoven, C. Molecular genetics of Alzheimer's disease: An update. Ann. Med. 2008, 40, 562-583. [CrossRef] [PubMed]

7. Bertram, L.; Tanzi, R.E. Alzheimer disease risk genes: 29 and counting. Nat. Rev. Neurol. 2019, 15, 191-192. [CrossRef] [PubMed]

8. Bettens, K.; Sleegers, K.; Van Broeckhoven, C. Genetic insights in Alzheimer's disease. Lancet Neurol. 2013, 12, 92-104. [CrossRef]

9. Xie, Y.; Li, J.; Kang, R.; Tang, D. Interplay between lipid metabolism and autophagy. Front Cell Dev Biol 2020, 8, 431. [CrossRef] [PubMed]

10. Birgisdottir, Å.B.; Johansen, T. Autophagy and endocytosis - interconnections and interdependencies. J. Cell Sci. 2020, 133, jcs228114. [CrossRef] [PubMed]

11. Nikoletopoulou, V.; Tavernarakis, N. Regulation and roles of autophagy at synapses. Trends Cell Biol. 2018, 28, 646-661. [PubMed]

12. Reddy, P.H.; Oliver, D.M. Amyloid beta and phosphorylated tau-induced defective autophagy and mitophagy in Alzheimer's disease. Cells 2019, 8, 488.

13. Loureiro, J.; Ploegh, H.L. Antigen presentation and the ubiquitin-Proteasome system in host-pathogen interactions. In Advances in Immunology; Academic Press: Cambridge, MA, USA, 2006; Volume 92, pp. 225-305.

14. LaFerla, F.M.; Green, K.N.; Oddo, S. Intracellular amyloid- $\beta$ in Alzheimer's disease. Nat. Rev. Neurosci. 2007, 8, 499-509. [PubMed]

15. Khurana, V.; Lindquist, S. Modelling neurodegeneration in Saccharomyces cerevisiae: Why cook with baker's yeast? Nat. Rev. Neurosci. 2010, 11, 436-449. [PubMed]

16. Seynnaeve, D.; Vecchio, M.D.; Fruhmann, G.; Verelst, J.; Cools, M.; Beckers, J.; Mulvihill, D.P.; Winderickx, J.; Franssens, V. Recent insights on Alzheimer's disease originating from yeast models. Int. J. Mol. Sci. 2018, 19, 1947.

17. Caine, J.; Sankovich, S.; Antony, H.; Waddington, L.; Macreadie, P.; Varghese, J.; Macreadie, I. Alzheimer's Abeta fused to green fluorescent protein induces growth stress and a heat shock response. FEMS Yeast Res. 2007, 7, 1230-1236. [PubMed]

18. Porzoor, A.; Alford, B.; Hügel, H.M.; Grando, D.; Caine, J.; Macreadie, I. Anti-amyloidogenic properties of some phenolic compounds. Biomolecules 2015, 5, 505-527.

19. Chen, X.; Petranovic, D. Amyloid- $\beta$ peptide-induced cytotoxicity and mitochondrial dysfunction in yeast. FEMS Yeast Res. 2015, 15, fov061.

20. Chen, X.; Bisschops, M.M.M.; Agarwal, N.R.; Ji, B.; Shanmugavel, K.P.; Petranovic, D. Interplay of energetics and ER stress exacerbates Alzheimer's amyloid- $\beta$ (A $\beta$ ) toxicity in yeast. Front. Mol. Neurosci. 2017, 10, 232.

21. Chen, X.; Ji, B.; Hao, X.; Li, X.; Eisele, F.; Nyström, T.; Petranovic, D. FMN reduces Amyloid- $\beta$ toxicity in yeast by regulating redox status and cellular metabolism. Nat. Commun. 2020, 11, 867.

22. Bharadwaj, P.R.; Martins, R.N. Autophagy modulates A $\beta$ accumulation and formation of aggregates in yeast. Mol. Cell. Neurosci. 2020, 104, 103466. [CrossRef] [PubMed]

23. Macreadie, I.G.; Arvanitis, C.; Bharadwaj, P. Finding chemopreventatives to reduce amyloid beta in yeast. Neural Regen Res. 2016, 11, 244-245. [CrossRef]

24. Macreadie, I.; Dhakal, S. Insights from yeast on oxidative stress in Alzheimer's disease, focusing on Ahp1p/Prx5. OBM Geriartrics 2019, 3, 10. [CrossRef]

25. Mcdonald, J.B.; Dhakal, S.; Macreadie, I.G. Yeast contributions to Alzheimer's Disease. J. Human. Clin. Gen. 2020, 2, 1-19. [CrossRef]

26. Webster, B.M.; Gildea, H.K.; Dillin, A. Protein homeostasis from the outside in. Nat. Cell Biol. 2020, 22, 911-912. [CrossRef]

27. Liberek, K.; Lewandowska, A.; Zietkiewicz, S. Chaperones in control of protein disaggregation. EMBO J. 2008, 27, 328-335. [CrossRef] [PubMed] 
28. Verghese, J.; Abrams, J.; Wang, Y.; Morano, K.A. Biology of the heat shock response and protein chaperones: Budding yeast (Saccharomyces cerevisiae) as a model system. Microbiol. Mol. Biol. Rev. 2012, 76, 115-158. [CrossRef] [PubMed]

29. Hartl, F.U.; Bracher, A.; Hayer-Hartl, M. Molecular chaperones in protein folding and proteostasis. Nature 2011, 475, 324-332. [CrossRef]

30. Hipp, M.S.; Kasturi, P.; Hartl, F.U. The proteostasis network and its decline in ageing. Nat. Rev. Mol. Cell Biol. 2019, 20, 421-435. [CrossRef]

31. Morawe, T.; Hiebel, C.; Kern, A.; Behl, C. Protein homeostasis, aging and Alzheimer's disease. Mol. Neurobiol. 2012, 46, 41-54. [CrossRef]

32. Cheng, J.; North, B.J.; Zhang, T.; Dai, X.; Tao, K.; Guo, J.; Wei, W. The emerging roles of protein homeostasis-governing pathways in Alzheimer's disease. Aging Cell 2018, 17, e12801.

33. Englander, S.W.; Mayne, L. The nature of protein folding pathways. Proc. Natl. Acad. Sci. USA 2014, 111, 15873.

34. Vabulas, R.M.; Raychaudhuri, S.; Hayer-Hartl, M.; Hartl, F.U. Protein folding in the cytoplasm and the heat shock response. Cold Spring. Harb. Perspect Biol. 2010, 2, a004390.

35. Skach, W.R. Cellular mechanisms of membrane protein folding. Nat. Struct Mol. Biol. 2009, 16, 606-612.

36. Hetz, C. The unfolded protein response: Controlling cell fate decisions under ER stress and beyond. Nat. Rev. Mol. Cell Biol. 2012, 13, 89-102.

37. Mori, K. Signalling Pathways in the unfolded protein response: Development from yeast to mammals. J. Biochem. 2009, 146, 743-750.

38. Chakrabarti, A.; Chen, A.W.; Varner, J.D. A review of the mammalian unfolded protein response. Biotechnol. Bioeng. 2011, 108, 2777-2793.

39. Schröder, M.; Kaufman, R.J. ER stress and the unfolded protein response. Mutat. Res./Fundam. Mol. Mech. Mutagenesis 2005, 569, 29-63.

40. Guerra-Moreno, A.; Ang, J.; Welsch, H.; Jochem, M.; Hanna, J. Regulation of the unfolded protein response in yeast by oxidative stress. FEBS Lett. 2019, 593, 1080-1088.

41. Wu, H.; Ng, B.S.; Thibault, G. Endoplasmic reticulum stress response in yeast and humans. Biosci. Rep. 2014, $34, \mathrm{e} 00118$.

42. Okamura, K.; Kimata, Y.; Higashio, H.; Tsuru, A.; Kohno, K. Dissociation of Kar2p/BiP from an ER sensory molecule, Ire1p, triggers the unfolded protein response in yeast. Biochem. Biophys. Res. Commun. 2000, 279, 445-450. [PubMed]

43. Sidrauski, C.; Walter, P. The transmembrane kinase Ire1p is a site-specific endonuclease that initiates mRNA splicing in the unfolded protein response. Cell 1997, 90, 1031-1039.

44. Tsvetanova, N.G.; Riordan, D.P.; Brown, P.O. The yeast rab GTPase Ypt1 modulates unfolded protein response dynamics by regulating the stability of HAC1 RNA. PLoS Genet. 2012, 8, e1002862.

45. Mori, T.; Ogasawara, C.; Inada, T.; Englert, M.; Beier, H.; Takezawa, M.; Endo, T.; Yoshihisa, T. Dual functions of yeast tRNA ligase in the unfolded protein response: Unconventional cytoplasmic splicing of HAC1 pre-mRNA is not sufficient to release translational attenuation. Mol. Biol. Cell 2010, 21, 3722-3734. [PubMed]

46. Ogawa, N.; Mori, K. Autoregulation of the $H A C 1$ gene is required for sustained activation of the yeast unfolded protein response. Genes Cells 2004, 9, 95-104. [CrossRef] [PubMed]

47. Hwang, J.; Qi, L. Quality control in the endoplasmic reticulum: Crosstalk between ERAD and UPR pathways. Trends Biochem. Sci. 2018, 43, 593-605. [CrossRef]

48. Protter, D.S.W.; Parker, R. Principles and properties of stress granules. Trends Cell Biol. 2016, 26, 668-679. [CrossRef]

49. Buchan, J.R.; Parker, R. Eukaryotic stress granules: The ins and outs of translation. Mol. Cell 2009, 36, 932-941. [CrossRef]

50. Hetz, C.; Zhang, K.; Kaufman, R.J. Mechanisms, regulation and functions of the unfolded protein response. Nat. Rev. Mol. Cell Biol. 2020, 21, 421-438. [CrossRef]

51. Plumb, R.; Zhang, Z.-R.; Appathurai, S.; Mariappan, M. A functional link between the co-translational protein translocation pathway and the UPR. eLife 2015, 4, e07426. [CrossRef]

52. Adachi, Y.; Yamamoto, K.; Okada, T.; Yoshida, H.; Harada, A.; Mori, K. ATF6 is a transcription factor specializing in the regulation of quality control proteins in the endoplasmic reticulum. Cell Struct. Funct. 2008, 33, 75-89. [CrossRef] 
53. Galehdar, Z.; Swan, P.; Fuerth, B.; Callaghan, S.M.; Park, D.S.; Cregan, S.P. Neuronal apoptosis induced by endoplasmic reticulum stress is regulated by ATF4-CHOP-mediated induction of the Bcl-2 homology 3-only member PUMA. J. Neurosci. 2010, 30, 16938. [CrossRef] [PubMed]

54. Novoa, I.; Zeng, H.; Harding, H.P.; Ron, D. Feedback inhibition of the unfolded protein response by GADD34-mediated dephosphorylation of eIF2 $\alpha$. J. Cell Biol. 2001, 153, 1011-1022. [CrossRef] [PubMed]

55. Landau, G.; Kodali, V.K.; Malhotra, J.D.; Kaufman, R.J. Chapter Fourteen-Detection of oxidative damage in response to protein misfolding in the endoplasmic reticulum. In Methods in Enzymology; Cadenas, E., Packer, L., Eds.; Academic Press: Cambridge, MA, USA, 2013; Volume 526, pp. 231-250.

56. Tabas, I.; Ron, D. Integrating the mechanisms of apoptosis induced by endoplasmic reticulum stress. Nat. Cell Biol. 2011, 13, 184-190. [CrossRef]

57. Rose, M.D.; Misra, L.M.; Vogel, J.P. KAR2, a karyogamy gene, is the yeast homolog of the mammalian BiP/GRP78 gene. Cell 1989, 57, 1211-1221. [CrossRef]

58. Zhang, L.; Zhang, C.; Wang, A. Divergence and conservation of the major UPR branch IRE1-bZIP signaling pathway across eukaryotes. Sci. Rep. 2016, 6, 27362. [CrossRef]

59. Kohno, K. Stress-sensing mechanisms in the unfolded protein response: Similarities and differences between yeast and mammals. J. Biochem. 2010, 147, 27-33. [CrossRef]

60. Laurino, J.P.; Thompson, G.M.; Pacheco, E.; Castilho, B.A. The beta subunit of eukaryotic translation initiation factor 2 binds mRNA through the lysine repeats and a region comprising the C2-C2 motif. Mol. Cell. Biol. 1999, 19, 173-181. [CrossRef]

61. Finley, D.; Ulrich, H.D.; Sommer, T.; Kaiser, P. The ubiquitin-proteasome system of Saccharomyces cerevisiae. Genetics 2012, 192, 319-360. [CrossRef]

62. Vaden, J.H.; Tian, T.; Golf, S.; McLean, J.W.; Wilson, J.A.; Wilson, S.M. Chronic over-expression of ubiquitin impairs learning, reduces synaptic plasticity, and enhances GRIA receptor turnover in mice. J. Neurochem. 2019, 148, 386-399. [CrossRef]

63. Rinetti, G.V.; Schweizer, F.E. Ubiquitination acutely regulates presynaptic neurotransmitter release in mammalian neurons. J. Neurosci. 2010, 30, 3157. [PubMed]

64. Speese, S.D.; Trotta, N.; Rodesch, C.K.; Aravamudan, B.; Broadie, K. The ubiquitin proteasome system acutely regulates presynaptic protein turnover and synaptic efficacy. Curr. Biol. 2003, 13, 899-910.

65. Sun, L.; Fan, G.; Shan, P.; Qiu, X.; Dong, S.; Liao, L.; Yu, C.; Wang, T.; Gu, X.; Li, Q.; et al. Regulation of energy homeostasis by the ubiquitin-independent REG $\gamma$ proteasome. Nat. Commun. 2016, 7, 12497.

66. Cheon, S.; Dean, M.; Chahrour, M. The ubiquitin proteasome pathway in neuropsychiatric disorders. Neurobiol. Learn. Mem. 2019, 165, 106791. [PubMed]

67. Lambert-Smith, I.A.; Saunders, D.N.; Yerbury, J.J. The pivotal role of ubiquitin-activating enzyme E1 (UBA1) in neuronal health and neurodegeneration. Int. J. Biochem. Cell Biol. 2020, 123, 105746.

68. Muratani, M.; Tansey, W.P. How the ubiquitin-proteasome system controls transcription. Nat. Rev. Mol. Cell Biol. 2003, 4, 192-201.

69. Braten, O.; Livneh, I.; Ziv, T.; Admon, A.; Kehat, I.; Caspi, L.H.; Gonen, H.; Bercovich, B.; Godzik, A.; Jahandideh, S.; et al. Numerous proteins with unique characteristics are degraded by the $26 \mathrm{~S}$ proteasome following monoubiquitination. Proc. Natl. Acad. Sci. USA 2016, 113, E4639.

70. Ohtake, F.; Tsuchiya, H.; Saeki, Y.; Tanaka, K. K63 ubiquitylation triggers proteasomal degradation by seeding branched ubiquitin chains. Proc. Natl. Acad. Sci. USA 2018, 115, E1401.

71. Ozkaynak, E.; Finley, D.; Solomon, M.J.; Varshavsky, A. The yeast ubiquitin genes: A family of natural gene fusions. EMBO J. 1987, 6, 1429-1439.

72. McGrath, J.P.; Jentsch, S.; Varshavsky, A. UBA 1: An essential yeast gene encoding ubiquitin-activating enzyme. EMBO J. 1991, 10, 227-236.

73. Seufert, W.; McGrath, J.P.; Jentsch, S. UBC1 encodes a novel member of an essential subfamily of yeast ubiquitin-conjugating enzymes involved in protein degradation. EMBO J. 1990, 9, 4535-4541. [CrossRef] [PubMed]

74. Shieh, H.L.; Chen, Y.; Brown, C.R.; Chiang, H.L. Biochemical analysis of fructose-1,6-bisphosphatase import into vacuole import and degradation vesicles reveals a role for UBC1 in vesicle biogenesis. J. Biol. Chem. 2001, 276, 10398-10406. [PubMed]

75. Preston, G.M.; Brodsky, J.L. The evolving role of ubiquitin modification in endoplasmic reticulum-associated degradation. Biochem. J. 2017, 474, 445-469. [CrossRef] 
76. Silva, G.M.; Finley, D.; Vogel, C. K63 polyubiquitination is a new modulator of the oxidative stress response. Nat. Struct Mol. Biol. 2015, 22, 116-123. [CrossRef] [PubMed]

77. Prakash, S.; Sung, P.; Prakash, L. DNA repair genes and proteins of Saccharomyces cerevisiae. Annu. Rev. Genet. 1993, 27, 33-70. [CrossRef] [PubMed]

78. Craig, K.L.; Tyers, M. The F-box: A new motif for ubiquitin dependent proteolysis in cell cycle regulation and signal transduction. Prog. Biophys. Mol. Biol. 1999, 72, 299-328. [CrossRef]

79. Tkach, J.M.; Yimit, A.; Lee, A.Y.; Riffle, M.; Costanzo, M.; Jaschob, D.; Hendry, J.A.; Ou, J.; Moffat, J.; Boone, C.; et al. Dissecting DNA damage response pathways by analysing protein localization and abundance changes during DNA replication stress. Nat. Cell Biol. 2012, 14, 966-976. [CrossRef] [PubMed]

80. Parag, H.A.; Dimitrovsky, D.; Raboy, B.; Kulka, R.G. Selective ubiquitination of calmodulin by UBC4 and a putative ubiquitin protein ligase (E3) from Saccharomyces Cerevisiae. FEBS Lett. 1993, 325, 242-246. [CrossRef]

81. Singh, R.K.; Kabbaj, M.H.; Paik, J.; Gunjan, A. Histone levels are regulated by phosphorylation and ubiquitylation-dependent proteolysis. Nat. Cell Biol. 2009, 11, 925-933. [CrossRef]

82. Haworth, J.; Alver, R.C.; Anderson, M.; Bielinsky, A.K. Ubc4 and Not4 regulate steady-state levels of DNA polymerase- $\alpha$ to promote efficient and accurate DNA replication. Mol. Biol. Cell 2010, 21, 3205-3219. [CrossRef]

83. Xu, P.; Duong, D.M.; Seyfried, N.T.; Cheng, D.; Xie, Y.; Robert, J.; Rush, J.; Hochstrasser, M.; Finley, D.; Peng, J. Quantitative proteomics reveals the function of unconventional ubiquitin chains in proteasomal degradation. Cell 2009, 137, 133-145. [CrossRef]

84. Swanson, R.; Locher, M.; Hochstrasser, M. A conserved ubiquitin ligase of the nuclear envelope/endoplasmic reticulum that functions in both ER-associated and Mat $\alpha 2$ repressor degradation. Genes Dev. 2001, 15, 2660-2674. [CrossRef] [PubMed]

85. Schüle, T.; Rose, M.; Entian, K.D.; Thumm, M.; Wolf, D.H. Ubc8p functions in catabolite degradation of fructose-1, 6-bisphosphatase in yeast. EMBO J. 2000, 19, 2161-2167. [CrossRef] [PubMed]

86. Dieckhoff, P.; Bolte, M.; Sancak, Y.; Braus, G.H.; Irniger, S. Smt3/SUMO and Ubc9 are required for efficient APC/C-mediated proteolysis in budding yeast. Mol. Microbiol. 2004, 51, 1375-1387. [CrossRef]

87. Eckert, J.H.; Johnsson, N. Pex10p links the ubiquitin conjugating enzyme Pex4p to the protein import machinery of the peroxisome. J. Cell Sci. 2003, 116, 3623-3634. [CrossRef] [PubMed]

88. Brusky, J.; Zhu, Y.; Xiao, W. UBC13, a DNA-damage-inducible gene, is a member of the error-free postreplication repair pathway in Saccharomyces cerevisiae. Curr. Genet. 2000, 37, 168-174. [CrossRef] [PubMed]

89. Vanácová, S.; Wolf, J.; Martin, G.; Blank, D.; Dettwiler, S.; Friedlein, A.; Langen, H.; Keith, G.; Keller, W. A new yeast poly(A) polymerase complex involved in RNA quality control. PLoS Biol. 2005, 3, e189. [CrossRef] [PubMed]

90. Kohlmann, S.; Schäfer, A.; Wolf, D.H. Ubiquitin ligase Hul5 is required for fragment-specific substrate degradation in endoplasmic reticulum-associated degradation. J. Biol. Chem. 2008, 283, 16374-16383. [CrossRef]

91. Aviram, S.; Kornitzer, D. The ubiquitin ligase Hul5 promotes proteasomal processivity. Mol. Cell. Biol. 2010, 30, 985-994. [CrossRef]

92. Fang, N.N.; Chan, G.T.; Zhu, M.; Comyn, S.A.; Persaud, A.; Deshaies, R.J.; Rotin, D.; Gsponer, J.; Mayor, T. Rsp5/Nedd4 is the main ubiquitin ligase that targets cytosolic misfolded proteins following heat stress. Nat. Cell Biol. 2014, 16, 1227-1237. [CrossRef]

93. Kaida, D.; Toh-e, A.; Kikuchi, Y. Rsp5-Bul1/2 complex is necessary for the HSE-mediated gene expression in budding yeast. Biochem. Biophys. Res. Commun. 2003, 306, 1037-1041. [CrossRef]

94. Hatakeyama, R.; Kamiya, M.; Takahara, T.; Maeda, T. Endocytosis of the aspartic acid/glutamic acid transporter Dip5 is triggered by substrate-dependent recruitment of the Rsp5 ubiquitin ligase via the arrestin-like protein Aly2. Mol. Cell. Biol. 2010, 30, 5598-5607. [CrossRef]

95. Duncan, K.; Umen, J.G.; Guthrie, C. A putative ubiquitin ligase required for efficient mRNA export differentially affects hnRNP transport. Curr. Biol. Cb 2000, 10, 687-696. [CrossRef]

96. Kim, D.H.; Zhang, W.; Koepp, D.M. The Hect domain E3 ligase Tom1 and the F-box protein Dia2 control Cdc6 degradation in G1 phase. J. Biol. Chem. 2012, 287, 44212-44220. [CrossRef] [PubMed] 
97. Daulny, A.; Geng, F.; Muratani, M.; Geisinger, J.M.; Salghetti, S.E.; Tansey, W.P. Modulation of RNA polymerase II subunit composition by ubiquitylation. Proc. Natl. Acad. Sci. USA 2008, 105, 19649-19654. [CrossRef]

98. Zou, W.; Yan, J.; Zhao, N.; Niu, S.; Huang, X. A novel role for the alcohol sensitive ring/PHD finger protein Asr1p in regulating cell cycle mediated by septin-dependent assembly in yeast. Biochem. Biophys. Res. Commun. 2015, 458, 208-213. [CrossRef]

99. Wood, A.; Krogan, N.J.; Dover, J.; Schneider, J.; Heidt, J.; Boateng, M.A.; Dean, K.; Golshani, A.; Zhang, Y.; Greenblatt, J.F.; et al. Bre1, an E3 ubiquitin ligase required for recruitment and substrate selection of Rad6 at a promoter. Mol. Cell 2003, 11, 267-274. [CrossRef]

100. Wysocki, R.; Javaheri, A.; Allard, S.; Sha, F.; Côté, J.; Kron, S.J. Role of Dot1-dependent histone H3 methylation in G1 and S phase DNA damage checkpoint functions of Rad9. Mol. Cell. Biol. 2005, 25, 8430-8443. [CrossRef]

101. Moehle, E.A.; Ryan, C.J.; Krogan, N.J.; Kress, T.L.; Guthrie, C. The yeast SR-like protein Npl3 links chromatin modification to mRNA processing. PLoS Genet. 2012, 8, e1003101. [CrossRef]

102. Bieganowski, P.; Shilinski, K.; Tsichlis, P.N.; Brenner, C. Cdc123 and checkpoint forkhead associated with RING proteins control the cell cycle by controlling eIF2gamma abundance. J. Biol. Chem. 2004, 279, 44656-44666. [CrossRef]

103. Singh, R.K.; Gonzalez, M.; Kabbaj, M.H.; Gunjan, A. Novel E3 ubiquitin ligases that regulate histone protein levels in the budding yeast Saccharomyces cerevisiae. PLoS ONE 2012, 7, e36295. [CrossRef] [PubMed]

104. Matsuo, Y.; Ikeuchi, K.; Saeki, Y.; Iwasaki, S.; Schmidt, C.; Udagawa, T.; Sato, F.; Tsuchiya, H.; Becker, T.; Tanaka, K.; et al. Ubiquitination of stalled ribosome triggers ribosome-associated quality control. Nat. Commun. 2017, 8, 159. [CrossRef] [PubMed]

105. Bordallo, J.; Plemper, R.K.; Finger, A.; Wolf, D.H. Der3p/Hrd1p is required for endoplasmic reticulumassociated degradation of misfolded lumenal and integral membrane proteins. Mol. Biol. Cell 1998, 9, 209-222. [CrossRef] [PubMed]

106. Regelmann, J.; Schüle, T.; Josupeit, F.S.; Horak, J.; Rose, M.; Entian, K.D.; Thumm, M.; Wolf, D.H. Catabolite degradation of fructose-1,6-bisphosphatase in the yeast Saccharomyces cerevisiae: A genome-wide screen identifies eight novel GID genes and indicates the existence of two degradation pathways. Mol. Biol. Cell 2003, 14, 1652-1663. [CrossRef]

107. Khoury, C.M.; Yang, Z.; Li, X.Y.; Vignali, M.; Fields, S.; Greenwood, M.T. A TSC22-like motif defines a novel antiapoptotic protein family. FEMS Yeast Res. 2008, 8, 540-563. [CrossRef]

108. Menssen, R.; Schweiggert, J.; Schreiner, J.; Kusevic, D.; Reuther, J.; Braun, B.; Wolf, D.H. Exploring the topology of the Gid complex, the E3 ubiquitin ligase involved in catabolite-induced degradation of gluconeogenic enzymes. J. Biol. Chem. 2012, 287, 25602-25614. [CrossRef]

109. Alvaro, D.; Lisby, M.; Rothstein, R. Genome-wide analysis of Rad52 foci reveals diverse mechanisms impacting recombination. PLoS Genet. 2007, 3, e228. [CrossRef]

110. Panasenko, O.; Landrieux, E.; Feuermann, M.; Finka, A.; Paquet, N.; Collart, M.A. The yeast Ccr4-Not complex controls ubiquitination of the nascent-associated polypeptide (NAC-EGD) complex. J. Biol. Chem. 2006, 281, 31389-31398. [CrossRef]

111. Denis, C.L.; Chiang, Y.C.; Cui, Y.; Chen, J. Genetic evidence supports a role for the yeast CCR4-NOT complex in transcriptional elongation. Genetics 2001, 158, 627-634.

112. Srivastava, A.; Woolford, C.A.; Jones, E.W. Pep3p/Pep5p complex: A putative docking factor at multiple steps of vesicular transport to the vacuole of Saccharomyces cerevisiae. Genetics 2000, 156, 105-122.

113. Sacksteder, K.A.; Gould, S.J. The genetics of peroxisome biogenesis. Annu. Rev. Genet. 2000, 34, 623-652. [PubMed]

114. Williams, C.; van den Berg, M.; Geers, E.; Distel, B. Pex10p functions as an E3 ligase for the Ubc4p-dependent ubiquitination of Pex5p. Biochem. Biophys. Res. Commun. 2008, 374, 620-624.

115. Platta, H.W.; El Magraoui, F.; Bäumer, B.E.; Schlee, D.; Girzalsky, W.; Erdmann, R. Pex2 and pex12 function as protein-ubiquitin ligases in peroxisomal protein import. Mol. Cell. Biol. 2009, 29, 5505-5516. [PubMed]

116. Shin, M.E.; Ogburn, K.D.; Varban, O.A.; Gilbert, P.M.; Burd, C.G. FYVE domain targets Pib1p ubiquitin ligase to endosome and vacuolar membranes. J. Biol. Chem. 2001, 276, 41388-41393. [PubMed]

117. Hewawasam, G.; Shivaraju, M.; Mattingly, M.; Venkatesh, S.; Martin-Brown, S.; Florens, L.; Workman, J.L.; Gerton, J.L. Psh1 is an E3 ubiquitin ligase that targets the centromeric histone variant Cse4. Mol. Cell 2010, 40, 444-454. [PubMed] 
118. Torres-Ramos, C.A.; Prakash, S.; Prakash, L. Requirement of RAD5 and MMS2 for postreplication repair of UV-damaged DNA in Saccharomyces cerevisiae. Mol. Cell. Biol. 2002, 22, 2419-2426. [PubMed]

119. Blastyák, A.; Pintér, L.; Unk, I.; Prakash, L.; Prakash, S.; Haracska, L. Yeast Rad5 protein required for postreplication repair has a DNA helicase activity specific for replication fork regression. Mol. Cell 2007, 28, 167-175.

120. Tateishi, S.; Sakuraba, Y.; Masuyama, S.; Inoue, H.; Yamaizumi, M. Dysfunction of human Rad18 results in defective postreplication repair and hypersensitivity to multiple mutagens. Proc. Natl. Acad. Sci. USA 2000, 97, 7927-7932.

121. Ulrich, H.D. Regulating post-translational modifications of the eukaryotic replication clamp PCNA. Dna Repair 2009, 8, 461-469.

122. Braun, M.A.; Costa, P.J.; Crisucci, E.M.; Arndt, K.M. Identification of Rkr1, a nuclear RING domain protein with functional connections to chromatin modification in Saccharomyces cerevisiae. Mol. Cell. Biol. 2007, 27, 2800-2811.

123. Crowder, J.J.; Geigges, M.; Gibson, R.T.; Fults, E.S.; Buchanan, B.W.; Sachs, N.; Schink, A.; Kreft, S.G.; Rubenstein, E.M. Rkr1/Ltn1 ubiquitin ligase-mediated degradation of translationally stalled endoplasmic reticulum proteins. J. Biol. Chem. 2015, 290, 18454-18466. [CrossRef]

124. Matsuda, R.; Ikeuchi, K.; Nomura, S.; Inada, T. Protein quality control systems associated with no-go and nonstop mRNA surveillance in yeast. Genes Cells Devoted Mol. Cell. Mech. 2014, 19, 1-12.

125. Dasgupta, A.; Ramsey, K.L.; Smith, J.S.; Auble, D.T. Sir Antagonist 1 (San1) is a ubiquitin ligase. J. Biol. Chem. 2004, 279, 26830-26838. [CrossRef] [PubMed]

126. Amm, I.; Wolf, D.H. Molecular mass as a determinant for nuclear San1-dependent targeting of misfolded cytosolic proteins to proteasomal degradation. FEBS Lett. 2016, 590, 1765-1775. [CrossRef]

127. Ii, T.; Fung, J.; Mullen, J.R.; Brill, S.J. The yeast Slx5-Slx8 DNA integrity complex displays ubiquitin ligase activity. Cell Cycle (Georget. Tex.) 2007, 6, 2800-2809. [CrossRef]

128. Baker, L.A.; Ueberheide, B.M.; Dewell, S.; Chait, B.T.; Zheng, D.; Allis, C.D. The yeast Snt2 protein coordinates the transcriptional response to hydrogen peroxide-mediated oxidative stress. Mol. Cell. Biol. 2013, 33, 3735-3748. [PubMed]

129. Hochstrasser, M. Ubiquitin-dependent protein degradation. Annu. Rev. Genet. 1996, 30, 405-439.

130. Ohi, M.D.; Vander Kooi, C.W.; Rosenberg, J.A.; Ren, L.; Hirsch, J.P.; Chazin, W.J.; Walz, T.; Gould, K.L. Structural and functional analysis of essential pre-mRNA splicing factor Prp19p. Mol. Cell. Biol. 2005, 25, 451-460.

131. Lu, X.; Legerski, R.J. The Prp19/Pso4 core complex undergoes ubiquitylation and structural alterations in response to DNA damage. Biochem Biophys Res Commun 2007, 354, 968-974.

132. Hänzelmann, P.; Schäfer, A.; Völler, D.; Schindelin, H. Structural insights into functional modes of proteins involved in ubiquitin family pathways. Methods Mol. Biol. 2012, 832, 547-576.

133. Richly, H.; Rape, M.; Braun, S.; Rumpf, S.; Hoege, C.; Jentsch, S. A series of ubiquitin binding factors connects CDC48/p97 to substrate multiubiquitylation and proteasomal targeting. Cell 2005, 120, 73-84. [CrossRef]

134. Urakov, V.N.; Valouev, I.A.; Lewitin, E.I.; Paushkin, S.V.; Kosorukov, V.S.; Kushnirov, V.V.; Smirnov, V.N.; Ter-Avanesyan, M.D. Itt1p, a novel protein inhibiting translation termination in Saccharomyces cerevisiae. BMC Mol. Biol. 2001, 2, 9. [CrossRef]

135. Chiba, T.; Tanaka, K. Cullin-based ubiquitin ligase and its control by NEDD8-conjugating system. Curr. Protein Pept. Sci. 2004, 5, 177-184. [CrossRef] [PubMed]

136. Kamura, T.; Conaway, J.W.; Conaway, R.C. Roles of SCF and VHL ubiquitin ligases in regulation of cell growth. Prog. Mol. Subcell. Biol. 2002, 29, 1-15.

137. Ribar, B.; Prakash, L.; Prakash, S. ELA1 and CUL3 are required along with ELC1 for RNA polymerase II polyubiquitylation and degradation in DNA-damaged yeast cells. Mol. Cell. Biol. 2007, 27, 3211-3216. [CrossRef]

138. Fujii, K.; Kitabatake, M.; Sakata, T.; Miyata, A.; Ohno, M. A role for ubiquitin in the clearance of nonfunctional rRNAs. Genes Dev. 2009, 23, 963-974. [CrossRef] [PubMed]

139. Michel, J.J.; McCarville, J.F.; Xiong, Y. A role for Saccharomyces cerevisiae Cul8 ubiquitin ligase in proper anaphase progression. J. Biol. Chem. 2003, 278, 22828-22837. [CrossRef] [PubMed]

140. Connelly, C.; Hieter, P. Budding yeast SKP1 encodes an evolutionarily conserved kinetochore protein required for cell cycle progression. Cell 1996, 86, 275-285. [CrossRef] 
141. Seol, J.H.; Shevchenko, A.; Shevchenko, A.; Deshaies, R.J. Skp1 forms multiple protein complexes, including RAVE, a regulator of V-ATPase assembly. Nat Cell Biol 2001, 3, 384-391. [CrossRef]

142. Lejeune, D.; Chen, X.; Ruggiero, C.; Berryhill, S.; Ding, B.; Li, S. Yeast Elc1 plays an important role in global genomic repair but not in transcription coupled repair. Dna Repair 2009, 8, 40-50. [CrossRef]

143. Seol, J.H.; Feldman, R.M.; Zachariae, W.; Shevchenko, A.; Correll, C.C.; Lyapina, S.; Chi, Y.; Galova, M.; Claypool, J.; Sandmeyer, S.; et al. Cdc53/cullin and the essential Hrt1 RING-H2 subunit of SCF define a ubiquitin ligase module that activates the E2 enzyme Cdc34. Genes Dev. 1999, 13, 1614-1626. [PubMed]

144. Landry, B.D.; Doyle, J.P.; Toczyski, D.P.; Benanti, J.A. F-box protein specificity for G1 cyclins is dictated by subcellular localization. PLoS Genet 2012, 8, e1002851.

145. Feldman, R.M.; Correll, C.C.; Kaplan, K.B.; Deshaies, R.J. A complex of Cdc4p, Skp1p, and Cdc53p/cullin catalyzes ubiquitination of the phosphorylated CDK inhibitor Sic1p. Cell 1997, 91, 221-230. [CrossRef]

146. Smothers, D.B.; Kozubowski, L.; Dixon, C.; Goebl, M.G.; Mathias, N. The abundance of Met30p limits SCF(Met30p) complex activity and is regulated by methionine availability. Mol. Cell. Biol. 2000, 20, 7845-7852. [CrossRef]

147. Yen, J.L.; Flick, K.; Papagiannis, C.V.; Mathur, R.; Tyrrell, A.; Ouni, I.; Kaake, R.M.; Huang, L.; Kaiser, P. Signal-induced disassembly of the SCF ubiquitin ligase complex by Cdc48/p97. Mol. Cell 2012, 48, 288-297. [CrossRef]

148. Botuyan, M.V.; Koth, C.M.; Mer, G.; Chakrabartty, A.; Conaway, J.W.; Conaway, R.C.; Edwards, A.M.; Arrowsmith, C.H.; Chazin, W.J. Binding of elongin A or a von Hippel-Lindau peptide stabilizes the structure of yeast elongin C. Proc. Natl. Acad. Sci. USA 1999, 96, 9033-9038. [CrossRef]

149. Gillette, T.G.; Yu, S.; Zhou, Z.; Waters, R.; Johnston, S.A.; Reed, S.H. Distinct functions of the ubiquitin-proteasome pathway influence nucleotide excision repair. EMBO J. 2006, 25, 2529-2538. [PubMed]

150. Ho, Y.; Gruhler, A.; Heilbut, A.; Bader, G.D.; Moore, L.; Adams, S.L.; Millar, A.; Taylor, P.; Bennett, K.; Boutilier, K.; et al. Systematic identification of protein complexes in Saccharomyces cerevisiae by mass spectrometry. Nature 2002, 415, 180-183. [CrossRef]

151. Sipos, G.; Brickner, J.H.; Brace, E.J.; Chen, L.; Rambourg, A.; Kepes, F.; Fuller, R.S. Soi3p/Rav1p functions at the early endosome to regulate endocytic trafficking to the vacuole and localization of trans-Golgi network transmembrane proteins. Mol Biol Cell 2004, 15, 3196-3209. [CrossRef]

152. Smardon, A.M.; Tarsio, M.; Kane, P.M. The RAVE complex is essential for stable assembly of the yeast V-ATPase. J. Biol. Chem. 2002, 277, 13831-13839.

153. Escusa, S.; Camblong, J.; Galan, J.M.; Pinson, B.; Daignan-Fornier, B. Proteasome- and SCF-dependent degradation of yeast adenine deaminase upon transition from proliferation to quiescence requires a new F-box protein named Saf1p. Mol. Microbiol. 2006, 60, 1014-1025. [CrossRef] [PubMed]

154. Topper, L.M.; Campbell, M.S.; Tugendreich, S.; Daum, J.R.; Burke, D.J.; Hieter, P.; Gorbsky, G.J. The dephosphorylated form of the anaphase-promoting complex protein Cdc27/Apc3 concentrates on kinetochores and chromosome arms in mitosis. Cell Cycle (Georget. Tex.) 2002, 1, 282-292. [CrossRef]

155. Zachariae, W.; Nasmyth, K. Whose end is destruction: Cell division and the anaphase-promoting complex. Genes Dev. 1999, 13, 2039-2058. [CrossRef] [PubMed]

156. Passmore, L.A.; McCormack, E.A.; Au, S.W.; Paul, A.; Willison, K.R.; Harper, J.W.; Barford, D. Doc1 mediates the activity of the anaphase-promoting complex by contributing to substrate recognition. EMBO J. 2003, 22, 786-796. [CrossRef]

157. Zachariae, W.; Shevchenko, A.; Andrews, P.D.; Ciosk, R.; Galova, M.; Stark, M.J.; Mann, M.; Nasmyth, K. Mass spectrometric analysis of the anaphase-promoting complex from yeast: Identification of a subunit related to cullins. Science 1998, 279, 1216-1219. [CrossRef]

158. Rousseau, A.; Bertolotti, A. Regulation of proteasome assembly and activity in health and disease. Nat. Rev. Mol. Cell Biol. 2018, 19, 697-712. [CrossRef]

159. Bedford, L.; Paine, S.; Sheppard, P.W.; Mayer, R.J.; Roelofs, J. Assembly, structure, and function of the $26 \mathrm{~S}$ proteasome. Trends Cell Biol. 2010, 20, 391-401. [CrossRef]

160. Marshall, R.S.; Vierstra, R.D. Dynamic Regulation of the 26S Proteasome: From Synthesis to Degradation. Front. Mol. Biosci. 2019, 6, 40. [CrossRef] [PubMed]

161. Livneh, I.; Cohen-Kaplan, V.; Cohen-Rosenzweig, C.; Avni, N.; Ciechanover, A. The life cycle of the $26 \mathrm{~S}$ proteasome: From birth, through regulation and function, and onto its death. Cell Res. 2016, 26, 869-885. [CrossRef] 
162. Mannhaupt, G.; Schnall, R.; Karpov, V.; Vetter, I.; Feldmann, H. Rpn4p acts as a transcription factor by binding to PACE, a nonamer box found upstream of $26 \mathrm{~S}$ proteasomal and other genes in yeast. FEBS Lett. 1999, 450, 27-34. [CrossRef]

163. Ma, M.; Liu, Z.L. Comparative transcriptome profiling analyses during the lag phase uncover YAP1, PDR1, $P D R 3, R P N 4$, and HSF1 as key regulatory genes in genomic adaptation to the lignocellulose derived inhibitor HMF for Saccharomyces cerevisiae. BMC Genom. 2010, 11, 660. [CrossRef] [PubMed]

164. Tobias, J.W.; Varshavsky, A. Cloning and functional analysis of the ubiquitin-specific protease gene UBP1 of Saccharomyces cerevisiae. J. Biol. Chem. 1991, 266, 12021-12028. [PubMed]

165. Baker, R.T.; Tobias, J.W.; Varshavsky, A. Ubiquitin-specific proteases of Saccharomyces cerevisiae. Cloning of UBP2 and UBP3, and functional analysis of the UBP gene family. J. Biol. Chem. 1992, 267, 23364-23375. [PubMed]

166. Cohen, M.; Stutz, F.; Belgareh, N.; Haguenauer-Tsapis, R.; Dargemont, C. Ubp3 requires a cofactor, Bre5, to specifically de-ubiquitinate the COPII protein, Sec23. Nat. Cell Biol. 2003, 5, 661-667. [CrossRef]

167. Solé, C.; Nadal-Ribelles, M.; Kraft, C.; Peter, M.; Posas, F.; de Nadal, E. Control of Ubp3 ubiquitin protease activity by the Hog1 SAPK modulates transcription upon osmostress. EMBO J. 2011, 30, 3274-3284. [CrossRef]

168. Amerik, A.Y.; Nowak, J.; Swaminathan, S.; Hochstrasser, M. The Doa4 deubiquitinating enzyme is functionally linked to the vacuolar protein-sorting and endocytic pathways. Mol. Biol. Cell 2000, 11, 3365-3380. [CrossRef]

169. Swaminathan, S.; Amerik, A.Y.; Hochstrasser, M. The Doa4 deubiquitinating enzyme is required for ubiquitin homeostasis in yeast. Mol. Biol. Cell 1999, 10, 2583-2594. [CrossRef]

170. Hanna, J.; Hathaway, N.A.; Tone, Y.; Crosas, B.; Elsasser, S.; Kirkpatrick, D.S.; Leggett, D.S.; Gygi, S.P.; King, R.W.; Finley, D. Deubiquitinating enzyme Ubp6 functions noncatalytically to delay proteasomal degradation. Cell 2006, 127, 99-111. [CrossRef]

171. Böhm, S.; Szakal, B.; Herken, B.W.; Sullivan, M.R.; Mihalevic, M.J.; Kabbinavar, F.F.; Branzei, D.; Clark, N.L.; Bernstein, K.A. The budding yeast ubiquitin protease Ubp7 is a novel component involved in $\mathrm{S}$ phase progression. J. Biol. Chem. 2016, 291, 4442-4452. [CrossRef]

172. Henry, K.W.; Wyce, A.; Lo, W.S.; Duggan, L.J.; Emre, N.C.; Kao, C.F.; Pillus, L.; Shilatifard, A.; Osley, M.A.; Berger, S.L. Transcriptional activation via sequential histone H2B ubiquitylation and deubiquitylation, mediated by SAGA-associated Ubp8. Genes Dev. 2003, 17, 2648-2663. [CrossRef]

173. Gallego-Sánchez, A.; Andrés, S.; Conde, F.; San-Segundo, P.A.; Bueno, A. Reversal of PCNA ubiquitylation by Ubp10 in Saccharomyces cerevisiae. PLoS Genet. 2012, 8, e1002826.

174. Huh, W.K.; Falvo, J.V.; Gerke, L.C.; Carroll, A.S.; Howson, R.W.; Weissman, J.S.; O'Shea, E.K. Global analysis of protein localization in budding yeast. Nature 2003, 425, 686-691.

175. Debelyy, M.O.; Platta, H.W.; Saffian, D.; Hensel, A.; Thoms, S.; Meyer, H.E.; Warscheid, B.; Girzalsky, W.; Erdmann, R. Ubp15p, a ubiquitin hydrolase associated with the peroxisomal export machinery. J. Biol. Chem. 2011, 286, 28223-28234. [PubMed]

176. Ostapenko, D.; Burton, J.L.; Solomon, M.J. The Ubp15 deubiquitinase promotes timely entry into $S$ phase in Saccharomyces cerevisiae. Mol. Biol. Cell 2015, 26, 2205-2216. [PubMed]

177. Kinner, A.; Kölling, R. The yeast deubiquitinating enzyme Ubp16 is anchored to the outer mitochondrial membrane. FEBS Lett. 2003, 549, 135-140. [PubMed]

178. Verma, R.; Aravind, L.; Oania, R.; McDonald, W.H.; Yates, J.R., 3rd; Koonin, E.V.; Deshaies, R.J. Role of Rpn11 metalloprotease in deubiquitination and degradation by the $26 \mathrm{~S}$ proteasome. Science 2002, 298, 611-615.

179. Guterman, A.; Glickman, M.H. Complementary roles for Rpn11 and Ubp6 in deubiquitination and proteolysis by the proteasome. J. Biol. Chem. 2004, 279, 1729-1738.

180. Rumpf, S.; Jentsch, S. Functional division of substrate processing cofactors of the ubiquitin-selective Cdc 48 chaperone. Mol. Cell 2006, 21, 261-269.

181. Linghu, B.; Callis, J.; Goebl, M.G. Rub1p processing by Yuh1p is required for wild-type levels of Rub1p conjugation to Cdc53p. Eukaryot. Cell 2002, 1, 491-494.

182. Groll, M.; Ditzel, L.; Löwe, J.; Stock, D.; Bochtler, M.; Bartunik, H.D.; Huber, R. Structure of $20 S$ proteasome from yeast at 2.4 A resolution. Nature 1997, 386, 463-471.

183. Heinemeyer, W.; Tröndle, N.; Albrecht, G.; Wolf, D.H. PRE5 and PRE6, the last missing genes encoding $20 \mathrm{~S}$ proteasome subunits from yeast? Indication for a set of 14 different subunits in the eukaryotic proteasome core. Biochemistry 1994, 33, 12229-12237. [CrossRef] 
184. Georgatsou, E.; Georgakopoulos, T.; Thireos, G. Molecular cloning of an essential yeast gene encoding a proteasomal subunit. FEBS Lett. 1992, 299, 39-43. [CrossRef]

185. Jäger, S.; Groll, M.; Huber, R.; Wolf, D.H.; Heinemeyer, W. Proteasome beta-type subunits: Unequal roles of propeptides in core particle maturation and a hierarchy of active site function. J. Mol. Biol. 1999, 291, 997-1013. [CrossRef] [PubMed]

186. Arendt, C.S.; Hochstrasser, M. Identification of the yeast $20 S$ proteasome catalytic centers and subunit interactions required for active-site formation. Proc. Natl. Acad. Sci. USA 1997, 94, 7156-7161. [CrossRef]

187. Takeuchi, J.; Toh-e, A. Genetic evidence for interaction between components of the yeast $26 \mathrm{~S}$ proteasome: Combination of a mutation in RPN12 (a lid component gene) with mutations in RPT1 (an ATPase gene) causes synthetic lethality. Mol. Gen. Genet. Mgg 1999, 262, 145-153. [CrossRef] [PubMed]

188. Glickman, M.H.; Rubin, D.M.; Fried, V.A.; Finley, D. The regulatory particle of the Saccharomyces cerevisiae proteasome. Mol. Cell. Biol. 1998, 18, 3149-3162. [CrossRef] [PubMed]

189. McDonald, H.B.; Byers, B. A proteasome cap subunit required for spindle pole body duplication in yeast. J. Cell Biol. 1997, 137, 539-553. [CrossRef]

190. Gonzalez, F.; Delahodde, A.; Kodadek, T.; Johnston, S.A. Recruitment of a 19 S proteasome subcomplex to an activated promoter. Science 2002, 296, 548-550. [CrossRef]

191. Glickman, M.H.; Rubin, D.M.; Coux, O.; Wefes, I.; Pfeifer, G.; Cjeka, Z.; Baumeister, W.; Fried, V.A.; Finley, D. A subcomplex of the proteasome regulatory particle required for ubiquitin-conjugate degradation and related to the COP9-signalosome and eIF3. Cell 1998, 94, 615-623. [CrossRef]

192. Husnjak, K.; Elsasser, S.; Zhang, N.; Chen, X.; Randles, L.; Shi, Y.; Hofmann, K.; Walters, K.J.; Finley, D.; Dikic, I. Proteasome subunit Rpn13 is a novel ubiquitin receptor. Nature 2008, 453, 481-488. [CrossRef]

193. van Nocker, S.; Sadis, S.; Rubin, D.M.; Glickman, M.; Fu, H.; Coux, O.; Wefes, I.; Finley, D.; Vierstra, R.D. The multiubiquitin-chain-binding protein Mcb1 is a component of the $26 \mathrm{~S}$ proteasome in Saccharomyces cerevisiae and plays a nonessential, substrate-specific role in protein turnover. Mol. Cell. Biol. 1996, 16, 6020-6028. [CrossRef]

194. Bailly, E.; Reed, S.I. Functional characterization of Rpn3 uncovers a distinct 19 S proteasomal subunit requirement for ubiquitin-dependent proteolysis of cell cycle regulatory proteins in budding yeast. Mol. Cell. Biol. 1999, 19, 6872-6890. [CrossRef] [PubMed]

195. Santamaria, P.G.; Finley, D.; Ballesta, J.P.; Remacha, M. Rpn6p, a proteasome subunit from Saccharomyces cerevisiae, is essential for the assembly and activity of the $26 \mathrm{~S}$ proteasome. J. Biol. Chem. 2003, 278, 6687-6695. [CrossRef] [PubMed]

196. Dikic, I.; Elazar, Z. Mechanism and medical implications of mammalian autophagy. Nat. Rev. Mol. Cell Biol. 2018, 19, 349-364. [CrossRef] [PubMed]

197. Hansen, M.; Rubinsztein, D.C.; Walker, D.W. Autophagy as a promoter of longevity: Insights from model organisms. Nat. Rev. Mol. Cell Biol. 2018, 19, 579-593. [CrossRef] [PubMed]

198. Su, T.; Li, X.; Yang, M.; Shao, Q.; Zhao, Y.; Ma, C.; Wang, P. Autophagy: An intracellular degradation pathway regulating plant survival and stress response. Front. Plant Sci. 2020, 11, 164. [CrossRef] [PubMed]

199. Li, W.W.; Li, J.; Bao, J.K. Microautophagy: Lesser-known self-eating. Cell. Mol. Life Sci. Cmls 2012, 69, 1125-1136. [CrossRef]

200. Cuervo, A.M.; Wong, E. Chaperone-mediated autophagy: Roles in disease and aging. Cell Res. 2014, 24, 92-104. [CrossRef]

201. Feng, Y.; He, D.; Yao, Z.; Klionsky, D.J. The machinery of macroautophagy. Cell Res. 2014, $24,24-41$. [CrossRef]

202. Beese, C.J.; Brynjólfsdóttir, S.H.; Frankel, L.B. Selective autophagy of the protein homeostasis machinery: Ribophagy, proteaphagy and ER-phagy. Front. Cell Dev. Biol. 2020, 7, 373. [CrossRef]

203. Kirkin, V. History of the selective autophagy research: How did it begin and where does it stand today? J. Mol. Biol. 2020, 432, 3-27. [PubMed]

204. Farré, J.-C.; Subramani, S. Mechanistic insights into selective autophagy pathways: Lessons from yeast. Nat. Rev. Mol. Cell Biol. 2016, 17, 537-552. [PubMed]

205. Salminen, A.; Kauppinen, A.; Kaarniranta, K. AMPK/Snf1 signaling regulates histone acetylation: Impact on gene expression and epigenetic functions. Cell. Signal. 2016, 28, 887-895. [PubMed]

206. Sacitharan, P.K.; Bou-Gharios, G.; Edwards, J.R. SIRT1 directly activates autophagy in human chondrocytes. Cell Death Discov. 2020, 6, 41. 
207. Hong, S.-P.; Leiper, F.C.; Woods, A.; Carling, D.; Carlson, M. Activation of yeast Snf1 and mammalian AMP-activated protein kinase by upstream kinases. Proc. Natl. Acad. Sci. USA 2003, 100, 8839.

208. Hedbacker, K.; Carlson, M. SNF1/AMPK pathways in yeast. Front Biosci 2008, 13, 2408-2420.

209. Rodríguez-Colman, M.J.; Sorolla, M.A.; Vall-llaura, N.; Tamarit, J.; Ros, J.; Cabiscol, E. The FOX transcription factor $\mathrm{Hcm} 1$ regulates oxidative metabolism in response to early nutrient limitation in yeast. Role of Snf1 and Tor1/Sch9 kinases. Biochim. Et Biophys. Acta (Bba) Mol. Cell Res. 2013, 1833, 2004-2015.

210. Ghavidel, A.; Baxi, K.; Prusinkiewicz, M.; Swan, C.; Belak, Z.R.; Eskiw, C.H.; Carvalho, C.E.; Harkness, T.A. Rapid nuclear exclusion of $\mathrm{Hcm} 1$ in aging Saccharomyces cerevisiae leads to vacuolar alkalization and replicative senescence. G3 (Bethesda) 2018, 8, 1579-1592.

211. Rodriguez-Colman, M.J.; Reverter-Branchat, G.; Sorolla, M.A.; Tamarit, J.; Ros, J.; Cabiscol, E. The forkhead transcription factor $\mathrm{Hcm} 1$ promotes mitochondrial biogenesis and stress resistance in yeast. J. Biol. Chem. 2010, 285, 37092-37101.

212. Linke, C.; Klipp, E.; Lehrach, H.; Barberis, M.; Krobitsch, S. Fkh1 and Fkh2 associate with Sir2 to control CLB2 transcription under normal and oxidative stress conditions. Front. Physiol. 2013, 4, 173.

213. Murakami, H.; Aiba, H.; Nakanishi, M.; Murakami-Tonami, Y. Regulation of yeast forkhead transcription factors and FoxM1 by cyclin-dependent and polo-like kinases. Cell Cycle 2010, 9, 3253-3262. [CrossRef] [PubMed]

214. Madia, F.; Wei, M.; Yuan, V.; Hu, J.; Gattazzo, C.; Pham, P.; Goodman, M.F.; Longo, V.D. Oncogene homologue Sch9 promotes age-dependent mutations by a superoxide and Rev1/Polzeta-dependent mechanism. J. Cell Biol. 2009, 186, 509-523. [CrossRef] [PubMed]

215. Urban, J.; Soulard, A.; Huber, A.; Lippman, S.; Mukhopadhyay, D.; Deloche, O.; Wanke, V.; Anrather, D.; Ammerer, G.; Riezman, H.; et al. Sch9 is a major target of TORC1 in Saccharomyces cerevisiae. Mol. Cell 2007, 26, 663-674. [CrossRef] [PubMed]

216. McManus, E.J.; Alessi, D.R. TSC1-TSC2: A complex tale of PKB-mediated S6K regulation. Nat. Cell Biol. 2002, 4, E214-E216. [CrossRef] [PubMed]

217. Long, X.; Lin, Y.; Ortiz-Vega, S.; Yonezawa, K.; Avruch, J. Rheb binds and regulates the mTOR kinase. Curr. Biol. 2005, 15, 702-713. [CrossRef] [PubMed]

218. Kijanska, M.; Dohnal, I.; Reiter, W.; Kaspar, S.; Stoffel, I.; Ammerer, G.; Kraft, C.; Peter, M. Activation of Atg1 kinase in autophagy by regulated phosphorylation. Autophagy 2010, 6, 1168-1178. [CrossRef] [PubMed]

219. Hu, Z.; Raucci, S.; Jaquenoud, M.; Hatakeyama, R.; Stumpe, M.; Rohr, R.; Reggiori, F.; De Virgilio, C.; Dengjel, J. Multilayered control of protein turnover by TORC1 and Atg1. Cell Rep. 2019, 28, 3486-3496.e6. [CrossRef]

220. Kim, E.; Goraksha-Hicks, P.; Li, L.; Neufeld, T.P.; Guan, K.L. Regulation of TORC1 by Rag GTPases in nutrient response. Nat. Cell Biol. 2008, 10, 935-945. [CrossRef]

221. Vázquez-Ibarra, A.; Subirana, L.; Ongay-Larios, L.; Kawasaki, L.; Rojas-Ortega, E.; Rodríguez-González, M.; de Nadal, E.; Posas, F.; Coria, R. Activation of the Hog1 MAPK by the Ssk2/Ssk22 MAP3Ks, in the absence of the osmosensors, is not sufficient to trigger osmostress adaptation in Saccharomyces cerevisiae. FEBS J. 2018, 285, 1079-1096. [CrossRef]

222. Murakami, Y.; Tatebayashi, K.; Saito, H. Two adjacent docking sites in the yeast Hog1 mitogen-activated protein (MAP) kinase differentially interact with the Pbs2 MAP kinase kinase and the Ptp2 protein tyrosine phosphatase. Mol. Cell Biol. 2008, 28, 2481-2494. [CrossRef]

223. Manjithaya, R.; Jain, S.; Farré, J.-C.; Subramani, S. A yeast MAPK cascade regulates pexophagy but not other autophagy pathways. J. Cell Biol. 2010, 189, 303-310. [CrossRef] [PubMed]

224. Mao, K.; Wang, K.; Zhao, M.; Xu, T.; Klionsky, D.J. Two MAPK-signaling pathways are required for mitophagy in Saccharomyces cerevisiae. J. Cell Biol. 2011, 193, 755-767. [CrossRef] [PubMed]

225. Gualtieri, T.; Ragni, E.; Mizzi, L.; Fascio, U.; Popolo, L. The cell wall sensor Wsc1p is involved in reorganization of actin cytoskeleton in response to hypo-osmotic shock in Saccharomyces cerevisiae. Yeast (Chichesterengland) 2004, 21, 1107-1120. [CrossRef] [PubMed]

226. Mizushima, N. The role of the Atg1/ULK1 complex in autophagy regulation. Curr. Opin. Cell Biol. 2010, 22, 132-139. [CrossRef]

227. Nakatogawa, H. Mechanisms governing autophagosome biogenesis. Nat. Rev. Mol. Cell Biol. 2020, 21, 439-458. [CrossRef] 
228. Wang, S.; Li, Y.; Ma, C. Atg3 promotes Atg8 lipidation via altering lipid diffusion and rearrangement. Protein Sci. 2020, 29, 1511-1523. [CrossRef]

229. Martens, S.; Fracchiolla, D. Activation and targeting of ATG8 protein lipidation. Cell Discov. 2020, 6, 23. [CrossRef]

230. Hanada, T.; Noda, N.N.; Satomi, Y.; Ichimura, Y.; Fujioka, Y.; Takao, T.; Inagaki, F.; Ohsumi, Y. The Atg12-Atg5 conjugate has a novel E3-like activity for protein lipidation in autophagy. J. Biol. Chem. 2007, 282, 37298-37302. [CrossRef]

231. Kihara, A.; Noda, T.; Ishihara, N.; Ohsumi, Y. Two distinct Vps34 phosphatidylinositol 3-kinase complexes function in autophagy and carboxypeptidase Y sorting in Saccharomyces cerevisiae. J. Cell Biol. 2001, 152, 519-530. [CrossRef]

232. Komatsu, M.; Waguri, S.; Ueno, T.; Iwata, J.; Murata, S.; Tanida, I.; Ezaki, J.; Mizushima, N.; Ohsumi, Y.; Uchiyama, Y.; et al. Impairment of starvation-induced and constitutive autophagy in Atg7-deficient mice. J. Cell Biol. 2005, 169, 425-434. [CrossRef]

233. Abdollahzadeh, I.; Schwarten, M.; Gensch, T.; Willbold, D.; Weiergräber, O.H. The Atg8 family of proteins-Modulating shape and functionality of autophagic membranes. Front. Genet. 2017, 8, 109. [PubMed]

234. Feng, Y.; Klionsky, D.J. Autophagic membrane delivery through ATG9. Cell Res. 2017, 27, 161-162. [CrossRef]

235. Shintani, T.; Mizushima, N.; Ogawa, Y.; Matsuura, A.; Noda, T.; Ohsumi, Y. Apg10p, a novel protein-conjugating enzyme essential for autophagy in yeast. EMBO J. 1999, 18, 5234-5241. [CrossRef] [PubMed]

236. Kabeya, Y.; Kamada, Y.; Baba, M.; Takikawa, H.; Sasaki, M.; Ohsumi, Y. Atg17 functions in cooperation with Atg1 and Atg13 in yeast autophagy. Mol. Biol. Cell 2005, 16, 2544-2553. [PubMed]

237. Kametaka, S.; Okano, T.; Ohsumi, M.; Ohsumi, Y. Apg14p and Apg6/Vps30p form a protein complex essential for autophagy in the yeast, Saccharomyces cerevisiae. J. Biol. Chem. 1998, 273, 22284-22291. [CrossRef] [PubMed]

238. Meijer, W.H.; van der Klei, I.J.; Veenhuis, M.; Kiel, J.A. ATG genes involved in non-selective autophagy are conserved from yeast to man, but the selective Cvt and pexophagy pathways also require organism-specific genes. Autophagy 2007, 3, 106-116. [CrossRef] [PubMed]

239. Slessareva, J.E.; Routt, S.M.; Temple, B.; Bankaitis, V.A.; Dohlman, H.G. Activation of the phosphatidylinositol 3-kinase Vps34 by a G protein alpha subunit at the endosome. Cell 2006, 126, 191-203. [CrossRef] [PubMed]

240. Stjepanovic, G.; Baskaran, S.; Lin, M.G.; Hurley, J.H. Vps34 kinase domain dynamics regulate the autophagic PI 3-kinase complex. Mol. Cell 2017, 67, 528-534.e3. [CrossRef]

241. Kamada, Y.; Yoshino, K.; Kondo, C.; Kawamata, T.; Oshiro, N.; Yonezawa, K.; Ohsumi, Y. Tor directly controls the Atg1 kinase complex to regulate autophagy. Mol Cell Biol 2010, 30, 1049-1058.

242. Fujioka, Y.; Suzuki, S.W.; Yamamoto, H.; Kondo-Kakuta, C.; Kimura, Y.; Hirano, H.; Akada, R.; Inagaki, F.; Ohsumi, Y.; Noda, N.N. Structural basis of starvation-induced assembly of the autophagy initiation complex. Nat. Struct. Mol. Biol. 2014, 21, 513-521.

243. Reggiori, F.; Tucker, K.A.; Stromhaug, P.E.; Klionsky, D.J. The Atg1-Atg13 complex regulates Atg9 and Atg23 retrieval transport from the pre-autophagosomal structure. Dev. Cell 2004, 6, 79-90. [CrossRef]

244. Obara, K.; Sekito, T.; Niimi, K.; Ohsumi, Y. The Atg18-Atg2 complex is recruited to autophagic membranes via phosphatidylinositol 3-phosphate and exerts an essential function. J. Biol. Chem. 2008, 283, 23972-23980. [CrossRef] [PubMed]

245. Ichimura, Y.; Kirisako, T.; Takao, T.; Satomi, Y.; Shimonishi, Y.; Ishihara, N.; Mizushima, N.; Tanida, I.; Kominami, E.; Ohsumi, M.; et al. A ubiquitin-like system mediates protein lipidation. Nature 2000, 408, 488-492. [CrossRef] [PubMed]

246. Mizushima, N.; Sugita, H.; Yoshimori, T.; Ohsumi, Y. A new protein conjugation system in human. The counterpart of the yeast Apg12p conjugation system essential for autophagy. J. Biol. Chem. 1998, 273, 33889-33892. [CrossRef]

247. Wen, X.; Klionsky, D.J. An overview of macroautophagy in yeast. J. Mol. Biol. 2016, 428, 1681-1699. [CrossRef]

248. de Marcos Lousa, C.; Denecke, J. Lysosomal and vacuolar sorting: Not so different after all! Biochem Soc Trans 2016, 44, 891-897. [CrossRef]

249. Wang, C.-W.; Klionsky, D.J. The molecular mechanism of autophagy. Mol. Med. 2003, 9, 65-76. [CrossRef] 
250. Nair, U.; Jotwani, A.; Geng, J.; Gammoh, N.; Richerson, D.; Yen, W.-L.; Griffith, J.; Nag, S.; Wang, K.; Moss, T.; et al. SNARE proteins are required for macroautophagy. Cell 2011, 146, 290-302. [CrossRef]

251. Li, S.C.; Kane, P.M. The yeast lysosome-like vacuole: Endpoint and crossroads. Biochim Biophys Acta 2009, 1793, 650-663. [CrossRef]

252. Pamarthy, S.; Kulshrestha, A.; Katara, G.K.; Beaman, K.D. The curious case of vacuolar ATPase: Regulation of signaling pathways. Mol. Cancer 2018, 17, 41. [CrossRef]

253. Colacurcio, D.J.; Nixon, R.A. Disorders of lysosomal acidification-The emerging role of v-ATPase in aging and neurodegenerative disease. Ageing Res Rev 2016, 32, 75-88. [CrossRef]

254. Kane, P.M.; Smardon, A.M. Assembly and regulation of the yeast vacuolar H+-ATPase. J. Bioenerg. Biomembr. 2003, 35, 313-321. [CrossRef]

255. Wilms, T.; Swinnen, E.; Eskes, E.; Dolz-Edo, L.; Uwineza, A.; Van Essche, R.; Rosseels, J.; Zabrocki, P.; Cameroni, E.; Franssens, V.; et al. The yeast protein kinase Sch9 adjusts V-ATPase assembly/disassembly to control pH homeostasis and longevity in response to glucose availability. PLoS Genet. 2017, 13, e1006835. [CrossRef] [PubMed]

256. Hirata, R.; Ohsumk, Y.; Nakano, A.; Kawasaki, H.; Suzuki, K.; Anraku, Y. Molecular structure of a gene, VMA1, encoding the catalytic subunit of $\mathrm{H}(+)$-translocating adenosine triphosphatase from vacuolar membranes of Saccharomyces cerevisiae. J. Biol. Chem. 1990, 265, 6726-6733. [PubMed]

257. Ruckenstuhl, C.; Netzberger, C.; Entfellner, I.; Carmona-Gutierrez, D.; Kickenweiz, T.; Stekovic, S.; Gleixner, C.; Schmid, C.; Klug, L.; Sorgo, A.G.; et al. Lifespan extension by methionine restriction requires autophagy-dependent vacuolar acidification. PLoS Genet. 2014, 10, e1004347. [CrossRef] [PubMed]

258. Forgac, M. Structure and properties of the vacuolar (H+)-ATPases. J. Biol. Chem. 1999, 274, 12951-12954.

259. Vitavska, O.; Wieczorek, H.; Merzendorfer, H. A novel role for subunit $\mathrm{C}$ in mediating binding of the H+-V-ATPase to the actin cytoskeleton. J. Biol. Chem. 2003, 278, 18499-18505. [CrossRef]

260. Graham, L.A.; Hill, K.J.; Stevens, T.H. VMA8 encodes a 32-kDa V1 subunit of the Saccharomyces cerevisiae vacuolar $\mathrm{H}(+)$-ATPase required for function and assembly of the enzyme complex. J. Biol. Chem. 1995, 270, 15037-15044.

261. Xu, T.; Forgac, M. Subunit D (Vma8p) of the yeast vacuolar H+-ATPase plays a role in coupling of proton transport and ATP hydrolysis. J. Biol. Chem. 2000, 275, 22075-22081. [CrossRef]

262. Foury, F. The 31-kDa polypeptide is an essential subunit of the vacuolar ATPase in Saccharomyces cerevisiae. J. Biol. Chem. 1990, 265, 18554-18560.

263. Graham, L.A.; Hill, K.J.; Stevens, T.H. VMA7 encodes a novel 14-kDa subunit of the Saccharomyces cerevisiae vacuolar H(+)-ATPase complex. J. Biol. Chem. 1994, 269, 25974-25977.

264. Supeková, L.; Supek, F.; Nelson, N. The Saccharomyces cerevisiae VMA10 is an intron-containing gene encoding a novel 13-kDa subunit of vacuolar H(+)-ATPase. J. Biol. Chem. 1995, 270, 13726-13732. [CrossRef] [PubMed]

265. Ho, M.N.; Hirata, R.; Umemoto, N.; Ohya, Y.; Takatsuki, A.; Stevens, T.H.; Anraku, Y. VMA13 encodes a 54-kDa vacuolar $\mathrm{H}(+)$-ATPase subunit required for activity but not assembly of the enzyme complex in Saccharomyces cerevisiae. J. Biol. Chem. 1993, 268, 18286-18292. [PubMed]

266. Preston, R.A.; Murphy, R.F.; Jones, E.W. Assay of vacuolar pH in yeast and identification of acidification-defective mutants. Proc. Natl. Acad. Sci. USA 1989, 86, 7027-7031. [CrossRef] [PubMed]

267. Manolson, M.F.; Wu, B.; Proteau, D.; Taillon, B.E.; Roberts, B.T.; Hoyt, M.A.; Jones, E.W. STV1 gene encodes functional homologue of 95-kDa yeast vacuolar H(+)-ATPase subunit Vph1p. J. Biol. Chem. 1994, 269, 14064-14074. [PubMed]

268. Banerjee, S.; Clapp, K.; Tarsio, M.; Kane, P.M. Interaction of the late endo-lysosomal lipid PI(3,5)P2 with the Vph1 isoform of yeast V-ATPase increases its activity and cellular stress tolerance. J. Biol. Chem. 2019, 294, 9161-9171. [CrossRef]

269. Umemoto, N.; Yoshihisa, T.; Hirata, R.; Anraku, Y. Roles of the VMA3 gene product, subunit c of the vacuolar membrane $\mathrm{H}(+)$-ATPase on vacuolar acidification and protein transport. A study with VMA3-disrupted mutants of Saccharomyces cerevisiae. J. Biol. Chem. 1990, 265, 18447-18453.

270. Rane, H.S.; Bernardo, S.M.; Raines, S.M.; Binder, J.L.; Parra, K.J.; Lee, S.A. Candida albicans VMA3 is necessary for V-ATPase assembly and function and contributes to secretion and filamentation. Eukaryot Cell 2013, 12, 1369-1382. [CrossRef] 
271. Hirata, R.; Graham, L.A.; Takatsuki, A.; Stevens, T.H.; Anraku, Y. VMA11 and VMA16 encode second and third proteolipid subunits of the Saccharomyces cerevisiae vacuolar membrane H+-ATPase. J. Biol. Chem. 1997, 272, 4795-4803. [CrossRef]

272. Flannery, A.R.; Graham, L.A.; Stevens, T.H. Topological characterization of the c, c', and c" subunits of the vacuolar ATPase from the yeast Saccharomyces cerevisiae. J. Biol. Chem. 2004, 279, 39856-39862. [CrossRef]

273. Bauerle, C.; Ho, M.N.; Lindorfer, M.A.; Stevens, T.H. The Saccharomyces cerevisiae VMA6 gene encodes the 36-kDa subunit of the vacuolar H(+)-ATPase membrane sector. J. Biol. Chem. 1993, 268, 12749-12757.

274. Jia, C.; Zhang, K.; Zhang, D.; Yu, Q.; Zhao, Q.; Xiao, C.; Dong, Y.; Chu, M.; Li, M. Roles of VPH2 and VMA6 in localization of V-ATPase subunits, cell wall functions and filamentous development in Candida albicans. Fungal Genet. Biol. Fg B 2018, 114, 1-11. [CrossRef] [PubMed]

275. Compton, M.A.; Graham, L.A.; Stevens, T.H. Vma9p (subunit e) is an integral membrane V0 subunit of the yeast V-ATPase. J. Biol. Chem. 2006, 281, 15312-15319. [CrossRef] [PubMed]

276. Yu, L.; McPhee, C.K.; Zheng, L.; Mardones, G.A.; Rong, Y.; Peng, J.; Mi, N.; Zhao, Y.; Liu, Z.; Wan, F.; et al. Termination of autophagy and reformation of lysosomes regulated by mTOR. Nature 2010, 465, 942-946. [CrossRef] [PubMed]

277. Okamoto, K.; Kondo-Okamoto, N. Mitochondria and autophagy: Critical interplay between the two homeostats. Biochim. Et Biophys. Acta (Bba) Gen. Subj. 2012, 1820, 595-600. [CrossRef]

278. Dokladny, K.; Myers, O.B.; Moseley, P.L. Heat shock response and autophagy-Cooperation and control. Autophagy 2015, 11, 200-213. [CrossRef]

279. Russell, R.C.; Yuan, H.-X.; Guan, K.-L. Autophagy regulation by nutrient signaling. Cell Res. 2014, $24,42-57$. [CrossRef]

280. Mao, K.; Klionsky, D.J. AMPK activates autophagy by phosphorylating ULK1. Circ. Res. 2011, 108, 787-788. [CrossRef]

281. Carling, D.; Sanders, M.J.; Woods, A. The regulation of AMP-activated protein kinase by upstream kinases. Int. J. Obes. 2008, 32, S55-S59. [CrossRef]

282. Lan, F.; Cacicedo, J.M.; Ruderman, N.; Ido, Y. SIRT1 modulation of the acetylation status, cytosolic localization, and activity of LKB1. Possible role in AMP-activated protein kinase activation. J. Biol. Chem. 2008, 283, 27628-27635. [CrossRef]

283. Satoh, A.; Brace, C.S.; Rensing, N.; Cliften, P.; Wozniak, D.F.; Herzog, E.D.; Yamada, K.A.; Imai, S.-I. Sirt1 extends life span and delays aging in mice through the regulation of Nk2 homeobox 1 in the DMH and LH. Cell Metab 2013, 18, 416-430. [PubMed]

284. Cantó, C.; Menzies, K.J.; Auwerx, J. NAD(+) metabolism and the control of energy homeostasis: A balancing act between mitochondria and the nucleus. Cell Metab 2015, 22, 31-53. [PubMed]

285. Cerutti, R.; Pirinen, E.; Lamperti, C.; Marchet, S.; Sauve, A.A.; Li, W.; Leoni, V.; Schon, E.A.; Dantzer, F.; Auwerx, J.; et al. NAD(+)-dependent activation of Sirt1 corrects the phenotype in a mouse model of mitochondrial disease. Cell Metab 2014, 19, 1042-1049.

286. White, E. Autophagy and p53. Cold Spring Harb. Perspect. Med. 2016, 6, a026120. [CrossRef] [PubMed]

287. Jones, R.G.; Plas, D.R.; Kubek, S.; Buzzai, M.; Mu, J.; Xu, Y.; Birnbaum, M.J.; Thompson, C.B. AMP-activated protein kinase induces a p53-dependent metabolic checkpoint. Mol. Cell 2005, 18, 283-293. [CrossRef] [PubMed]

288. Yamaguchi, H.; Woods, N.T.; Piluso, L.G.; Lee, H.H.; Chen, J.; Bhalla, K.N.; Monteiro, A.; Liu, X.; Hung, M.C.; Wang, H.G. p53 acetylation is crucial for its transcription-independent proapoptotic functions. J. Biol. Chem. 2009, 284, 11171-11183. [PubMed]

289. Langley, E.; Pearson, M.; Faretta, M.; Bauer, U.-M.; Frye, R.A.; Minucci, S.; Pelicci, P.G.; Kouzarides, T. Human SIR2 deacetylates p53 and antagonizes PML/p53-induced cellular senescence. EMBO J. 2002, 21, 2383-2396. [PubMed]

290. Zhao, R.Z.; Jiang, S.; Zhang, L.; Yu, Z.B. Mitochondrial electron transport chain, ROS generation and uncoupling (Review). Int. J. Mol. Med. 2019, 44, 3-15.

291. Demers-Lamarche, J.; Guillebaud, G.; Tlili, M.; Todkar, K.; Bélanger, N.; Grondin, M.; Nguyen, A.P.; Michel, J.; Germain, M. Loss of mitochondrial function impairs lysosomes. J. Biol. Chem. 2016, 291, 10263-10276.

292. Cheng, X.-T.; Xie, Y.-X.; Zhou, B.; Huang, N.; Farfel-Becker, T.; Sheng, Z.-H. Revisiting LAMP1 as a marker for degradative autophagy-lysosomal organelles in the nervous system. Autophagy 2018, 14, 1472-1474. 
293. Deus, C.M.; Yambire, K.F.; Oliveira, P.J.; Raimundo, N. Mitochondria-lysosome crosstalk: From physiology to neurodegeneration. Trends Mol. Med. 2020, 26, 71-88. [CrossRef] [PubMed]

294. Chauhan, S.; Goodwin, J.G.; Chauhan, S.; Manyam, G.; Wang, J.; Kamat, A.M.; Boyd, D.D. ZKSCAN3 is a master transcriptional repressor of autophagy. Mol. Cell 2013, 50, 16-28. [CrossRef] [PubMed]

295. Kim, J.; Guan, K.-L. mTOR as a central hub of nutrient signalling and cell growth. Nat. Cell Biol. 2019, 21, 63-71. [CrossRef] [PubMed]

296. Kataoka, T.; Powers, S.; Cameron, S.; Fasano, O.; Goldfarb, M.; Broach, J.; Wigler, M. Functional homology of mammalian and yeast RAS genes. Cell 1985, 40, 19-26. [CrossRef]

297. Cazzanelli, G.; Pereira, F.; Alves, S.; Francisco, R.; Azevedo, L.; Dias Carvalho, P.; Almeida, A.; Côrte-Real, M.; Oliveira, M.J.; Lucas, C.; et al. The yeast Saccharomyces cerevisiae as a model for understanding RAS proteins and their role in human tumorigenesis. Cells 2018, 7, 14. [CrossRef]

298. Castellano, E.; Downward, J. RAS interaction with PI3K: More than just another effector pathway. Genes Cancer 2011, 2, 261-274. [CrossRef]

299. Bhaskar, P.T.; Hay, N. The two TORCs and Akt. Dev. Cell 2007, 12, 487-502. [CrossRef]

300. De Virgilio, C.; Loewith, R. The TOR signalling network from yeast to man. Int. J. Biochem. Cell Biol. 2006, 38, 1476-1481. [CrossRef]

301. Díaz-Troya, S.; Pérez-Pérez, M.E.; Florencio, F.J.; Crespo, J.L. The role of TOR in autophagy regulation from yeast to plants and mammals. Autophagy 2008, 4, 851-865. [CrossRef]

302. Sanz, P.; Viana, R.; Garcia-Gimeno, M.A. AMPK in yeast: The SNF1 (Sucrose Non-fermenting 1) protein kinase complex. EXS 2016, 107, 353-374.

303. Peña-Llopis, S.; Vega-Rubin-de-Celis, S.; Schwartz, J.C.; Wolff, N.C.; Tran, T.A.T.; Zou, L.; Xie, X.-J.; Corey, D.R.; Brugarolas, J. Regulation of TFEB and V-ATPases by mTORC1. EMBO J. 2011, 30, 3242-3258. [PubMed]

304. Roberts, D.J.; Tan-Sah, V.P.; Ding, E.Y.; Smith, J.M.; Miyamoto, S. Hexokinase-II positively regulates glucose starvation-induced autophagy through TORC1 inhibition. Mol. Cell 2014, 53, 521-533. [CrossRef]

305. Bootman, M.D.; Chehab, T.; Bultynck, G.; Parys, J.B.; Rietdorf, K. The regulation of autophagy by calcium signals: Do we have a consensus? Cell Calcium 2018, 70, 32-46. [CrossRef]

306. Milles, L.F.; Unterauer, E.M.; Nicolaus, T.; Gaub, H.E. Calcium stabilizes the strongest protein fold. Nat. Commun. 2018, 9, 4764. [CrossRef]

307. Mekahli, D.; Bultynck, G.; Parys, J.B.; De Smedt, H.; Missiaen, L. Endoplasmic-reticulum calcium depletion and disease. Cold Spring Harb. Perspect Biol. 2011, 3, a004317. [CrossRef] [PubMed]

308. Cakir, I.; Nillni, E.A. Endoplasmic reticulum stress, the hypothalamus, and energy balance. Trends Endocrinol. Metab. 2019, 30, 163-176. [CrossRef] [PubMed]

309. Ermak, G.; Davies, K.J.A. Calcium and oxidative stress: From cell signaling to cell death. Mol. Immunol. 2002, 38, 713-721. [CrossRef]

310. Santulli, G.; Xie, W.; Reiken, S.R.; Marks, A.R. Mitochondrial calcium overload is a key determinant in heart failure. Proc. Natl. Acad. Sci. USA 2015, 112, 11389-11394. [CrossRef]

311. Ghislat, G.; Patron, M.; Rizzuto, R.; Knecht, E. Withdrawal of essential amino acids increases autophagy by a pathway involving Ca2+/calmodulin-dependent kinase kinase- $\beta$ (CaMKK- $\beta$ ). J. Biol. Chem. 2012, 287, 38625-38636. [CrossRef]

312. Zündorf, G.; Reiser, G. Calcium dysregulation and homeostasis of neural calcium in the molecular mechanisms of neurodegenerative diseases provide multiple targets for neuroprotection. Antioxid. Redox Signal. 2011, 14, 1275-1288. [CrossRef]

313. Grotemeier, A.; Alers, S.; Pfisterer, S.G.; Paasch, F.; Daubrawa, M.; Dieterle, A.; Viollet, B.; Wesselborg, S.; Proikas-Cezanne, T.; Stork, B. AMPK-independent induction of autophagy by cytosolic Ca2+ increase. Cell Signal 2010, 22, 914-925. [CrossRef] [PubMed]

314. Filippi-Chiela, E.C.; Viegas, M.S.; Thomé, M.P.; Buffon, A.; Wink, M.R.; Lenz, G. Modulation of autophagy by calcium signalosome in human disease. Mol. Pharmacol. 2016, 90, 371. [CrossRef] [PubMed]

315. Coen, K.; Flannagan, R.S.; Baron, S.; Carraro-Lacroix, L.R.; Wang, D.; Vermeire, W.; Michiels, C.; Munck, S.; Baert, V.; Sugita, S.; et al. Lysosomal calcium homeostasis defects, not proton pump defects, cause endo-lysosomal dysfunction in PSEN-deficient cells. J. Cell Biol. 2012, 198, 23-35. [CrossRef] [PubMed]

316. Di Malta, C.; Cinque, L.; Settembre, C. Transcriptional regulation of autophagy: Mechanisms and diseases. Front. Cell Dev. Biol. 2019, 7, 114. [CrossRef]

317. Tuteja, G.; Kaestner, K.H. Forkhead transcription factors II. Cell 2007, 131, 192. [CrossRef] 
318. Jiao, R.; Postnikoff, S.; Harkness, T.A.; Arnason, T.G. The SNF1 kinase ubiquitin-associated domain restrains its activation, activity, and the yeast life span. J. Biol. Chem. 2015, 290, 15393-15404. [CrossRef]

319. Zhao, Y.; Yang, J.; Liao, W.; Liu, X.; Zhang, H.; Wang, S.; Wang, D.; Feng, J.; Yu, L.; Zhu, W.-G. Cytosolic FoxO1 is essential for the induction of autophagy and tumour suppressor activity. Nat. Cell Biol. 2010, 12, 665-675. [CrossRef]

320. Sanchez, A.M.J.; Csibi, A.; Raibon, A.; Cornille, K.; Gay, S.; Bernardi, H.; Candau, R. AMPK promotes skeletal muscle autophagy through activation of forkhead FoxO3a and interaction with Ulk1. J. Cell. Biochem. 2012, 113, 695-710. [CrossRef]

321. Füllgrabe, J.; Ghislat, G.; Cho, D.-H.; Rubinsztein, D.C. Transcriptional regulation of mammalian autophagy at a glance. J. Cell Sci. 2016, 129, 3059. [CrossRef]

322. Hariharan, N.; Maejima, Y.; Nakae, J.; Paik, J.; DePinho Ronald, A.; Sadoshima, J. Deacetylation of FoxO by Sirt1 plays an essential role in mediating starvation-induced autophagy in cardiac myocytes. Circ. Res. 2010, 107, 1470-1482. [CrossRef]

323. Zhang, X.; Tang, N.; Hadden, T.J.; Rishi, A.K. Akt, FoxO and regulation of apoptosis. Biochim. Et Biophys. Acta (Bba) Mol. Cell Res. 2011, 1813, 1978-1986. [CrossRef]

324. Nakka, V.P.; Prakash-babu, P.; Vemuganti, R. Crosstalk between endoplasmic reticulum stress, oxidative stress, and autophagy: Potential therapeutic targets for acute CNS injuries. Mol. Neurobiol. 2016, 53, 532-544. [CrossRef] [PubMed]

325. Luo, H.; Chiang, H.-H.; Louw, M.; Susanto, A.; Chen, D. Nutrient sensing and the oxidative stress response. Trends Endocrinol. Metab. 2017, 28, 449-460. [CrossRef] [PubMed]

326. Thannickal, V.J.; Fanburg, B.L. Reactive oxygen species in cell signaling. Am. J. Physiol. -Lung Cell. Mol. Physiol. 2000, 279, L1005-L1028. [CrossRef] [PubMed]

327. Fuse, Y.; Kobayashi, M. Conservation of the Keap1-Nrf2 system: An evolutionary journey through stressful space and time. Molecules 2017, 22, 436. [CrossRef]

328. Vomund, S.; Schäfer, A.; Parnham, M.J.; Brüne, B.; von Knethen, A. Nrf2, the master regulator of anti-oxidative responses. Int. J. Mol. Sci. 2017, 18, 2772. [CrossRef]

329. van der Laan, K.J.; Morita, A.; Perona-Martinez, F.P.; Schirhagl, R. Evaluation of the oxidative stress response of aging yeast cells in response to internalization of fluorescent nanodiamond biosensors. Nanomaterials 2020, 10, 372. [CrossRef] [PubMed]

330. Norris, E.H.; Giasson, B.I. Role of oxidative damage in protein aggregation associated with Parkinson's disease and related disorders. Antioxid. Redox Signal. 2005, 7, 672-684. [CrossRef]

331. Rezatabar, S.; Karimian, A.; Rameshknia, V.; Parsian, H.; Majidinia, M.; Kopi, T.A.; Bishayee, A.; Sadeghinia, A.; Yousefi, M.; Monirialamdari, M.; et al. RAS/MAPK signaling functions in oxidative stress, DNA damage response and cancer progression. J. Cell. Physiol. 2019, 234, 14951-14965. [CrossRef]

332. Morrison, D.K. MAP kinase pathways. Cold Spring Harb. Perspect Biol. 2012, 4, a011254. [CrossRef]

333. Till, A.; Lakhani, R.; Burnett, S.F.; Subramani, S. Pexophagy: The selective degradation of peroxisomes. Int. J. Cell Biol. 2012, 2012, 512721. [PubMed]

334. Courtial, L.; Picco, V.; Grover, R.; Cormerais, Y.; Rottier, C.; Labbe, A.; Pagès, G.; Ferrier-Pagès, C. The c-Jun $\mathrm{N}$-terminal kinase prevents oxidative stress induced by UV and thermal stresses in corals and human cells. Sci. Rep. 2017, 7, 45713. [PubMed]

335. Lorin, S.; Pierron, G.; Ryan, K.M.; Codogno, P.; Djavaheri-Mergny, M. Evidence for the interplay between JNK and p53-DRAM signaling pathways in the regulation of autophagy. Autophagy 2010, 6, 153-154. [CrossRef]

336. Xu, P.; Das, M.; Reilly, J.; Davis, R.J. JNK regulates FoxO-dependent autophagy in neurons. Genes Dev. 2011, 25, 310-322. [CrossRef]

337. Lin, X.; Wang, Y.-J.; Li, Q.; Hou, Y.-Y.; Hong, M.-H.; Cao, Y.-L.; Chi, Z.-Q.; Liu, J.-G. Chronic high-dose morphine treatment promotes SH-SY5Y cell apoptosis via c-Jun $\mathrm{N}$-terminal kinase-mediated activation of mitochondria-dependent pathway. FEBS J. 2009, 276, 2022-2036.

338. Kroemer, G.; Jäättelä, M. Lysosomes and autophagy in cell death control. Nat. Rev. Cancer 2005, 5, 886-897. [PubMed]

339. Marshansky, V.; Futai, M. The V-type H+-ATPase in vesicular trafficking: Targeting, regulation and function. Curr. Opin. Cell Biol. 2008, 20, 415-426. [CrossRef]

340. Parra, K.J.; Chan, C.-Y.; Chen, J. Saccharomyces cerevisiae vacuolar H+-ATPase regulation by disassembly and reassembly: One structure and multiple signals. Eukaryot Cell 2014, 13, 706-714. 
341. Collins, M.P.; Forgac, M. Regulation of V-ATPase assembly in nutrient sensing and function of V-ATPases in breast cancer metastasis. Front. Physiol. 2018, 9, 902.

342. Bond, S.; Forgac, M. The Ras/cAMP/protein kinase A pathway regulates glucose-dependent assembly of the vacuolar (H+)-ATPase in yeast. J. Biol. Chem. 2008, 283, 36513-36521. [CrossRef]

343. Smardon, A.M.; Diab, H.I.; Tarsio, M.; Diakov, T.T.; Nasab, N.D.; West, R.W.; Kane, P.M. The RAVE complex is an isoform-specific V-ATPase assembly factor in yeast. Mol. Biol. Cell 2014, 25, 356-367. [CrossRef] [PubMed]

344. Meo-Evoli, N.; Almacellas, E.; Massucci, F.A.; Gentilella, A.; Ambrosio, S.; Kozma, S.C.; Thomas, G.; Tauler, A. V-ATPase: A master effector of E2F1-mediated lysosomal trafficking, mTORC1 activation and autophagy. Oncotarget 2015, 6, 28057-28070. [CrossRef] [PubMed]

345. Zhang, C.-S.; Jiang, B.; Li, M.; Zhu, M.; Peng, Y.; Zhang, Y.-L.; Wu, Y.-Q.; Li, T.Y.; Liang, Y.; Lu, Z.; et al. The lysosomal v-ATPase-Ragulator complex is a common activator for AMPK and mTORC1, acting as a switch between catabolism and anabolism. Cell Metab. 2014, 20, 526-540. [CrossRef]

346. McGuire, C.M.; Forgac, M. Glucose starvation increases V-ATPase assembly and activity in mammalian cells through AMP kinase and phosphatidylinositide 3-kinase/Akt signaling. J. Biol. Chem. 2018, 293, 9113-9123. [CrossRef]

347. Zhang, C.S.; Li, M.; Zong, Y.; Lin, S.C. Determining AMPK activation via the lysosomal v-ATPaseRagulator-AXIN/LKB1 axis. Methods Mol. Biol. (Cliftonn. J.) 2018, 1732, 393-411.

348. Mputhia, Z.; Hone, E.; Tripathi, T.; Sargeant, T.; Martins, R.; Bharadwaj, P. Autophagy modulation as a treatment of amyloid diseases. Molecules 2019, 24, 3372. [CrossRef] [PubMed]

349. Ohno, M. Roles of eIF2 $\alpha$ kinases in the pathogenesis of Alzheimer's disease. Front Mol Neurosci 2014, 7, 22. [CrossRef]

350. Li, J.-Q.; Yu, J.-T.; Jiang, T.; Tan, L. Endoplasmic reticulum dysfunction in Alzheimer's disease. Mol. Neurobiol. 2015, 51, 383-395. [CrossRef]

351. Lee, J.H.; Won, S.M.; Suh, J.; Son, S.J.; Moon, G.J.; Park, U.J.; Gwag, B.J. Induction of the unfolded protein response and cell death pathway in Alzheimer's disease, but not in aged Tg2576 mice. Exp. Mol. Med. 2010, 42, 386-394. [CrossRef]

352. Nijholt, D.A.T.; Nölle, A.; van Haastert, E.S.; Edelijn, H.; Toonen, R.F.; Hoozemans, J.J.M.; Scheper, W. Unfolded protein response activates glycogen synthase kinase-3 via selective lysosomal degradation. Neurobiol. Aging 2013, 34, 1759-1771. [CrossRef]

353. LaFerla, F.M. Calcium dyshomeostasis and intracellular signalling in Alzheimer's disease. Nat. Rev. Neurosci. 2002, 3, 862-872. [CrossRef]

354. Butterfield, D.A.; Halliwell, B. Oxidative stress, dysfunctional glucose metabolism and Alzheimer disease. Nat. Rev. Neurosci. 2019, 20, 148-160. [CrossRef] [PubMed]

355. Vanderweyde, T.; Apicco, D.J.; Youmans-Kidder, K.; Ash, P.E.A.; Cook, C.; Lummertz da Rocha, E.; Jansen-West, K.; Frame, A.A.; Citro, A.; Leszyk, J.D.; et al. Interaction of tau with the RNA-binding protein TIA1 regulates tau pathophysiology and toxicity. Cell Rep. 2016, 15, 1455-1466. [CrossRef] [PubMed]

356. Gadhave, K.; Bolshette, N.; Ahire, A.; Pardeshi, R.; Thakur, K.; Trandafir, C.; Istrate, A.; Ahmed, S.; Lahkar, M.; Muresanu, D.F.; et al. The ubiquitin proteasomal system: A potential target for the management of Alzheimer's disease. J. Cell Mol. Med. 2016, 20, 1392-1407. [CrossRef] [PubMed]

357. Al Mamun, A.; Uddin, M.S.; Kabir, M.T.; Khanum, S.; Sarwar, M.S.; Mathew, B.; Rauf, A.; Ahmed, M.; Ashraf, G.M. Exploring the promise of targeting ubiquitin-proteasome system to combat Alzheimer's disease. Neurotox. Res. 2020, 38, 8-17. [CrossRef] [PubMed]

358. Choi, J.; Gao, J.; Kim, J.; Hong, C.; Kim, J.; Tontonoz, P. The E3 ubiquitin ligase Idol controls brain LDL receptor expression, ApoE clearance, and A $\beta$ amyloidosis. Sci. Transl. Med. 2015, 7, 314ra184. [CrossRef]

359. Lee, M.J.; Lee, J.H.; Rubinsztein, D.C. Tau degradation: The ubiquitin-proteasome system versus the autophagy-lysosome system. Prog. Neurobiol. 2013, 105, 49-59. [CrossRef]

360. Toral-Rios, D.; Pichardo-Rojas, P.S.; Alonso-Vanegas, M.; Campos-Peña, V. GSK3 $\beta$ and tau protein in Alzheimer's Disease and epilepsy. Front. Cell. Neurosci. 2020, 14, 19. [CrossRef]

361. Nair, S.; Traini, M.; Dawes, I.W.; Perrone, G.G. Genome-wide analysis of Saccharomyces cerevisiae identifies cellular processes affecting intracellular aggregation of Alzheimer's amyloid- $\beta 42$ : Importance of lipid homeostasis. Mol. Biol. Cell 2014, 25, 2235-2249. [CrossRef]

362. Nixon, R.A.; Yang, D.S. Autophagy failure in Alzheimer's disease-Locating the primary defect. Neurobiol. Dis. 2011, 43, 38-45. [CrossRef] 
363. Piras, A.; Collin, L.; Grüninger, F.; Graff, C.; Rönnbäck, A. Autophagic and lysosomal defects in human tauopathies: Analysis of post-mortem brain from patients with familial Alzheimer disease, corticobasal degeneration and progressive supranuclear palsy. Acta Neuropathol. Commun. 2016, 4, 22. [CrossRef] [PubMed]

364. Hu, G.; Rios, L.; Yan, Z.; Jasper, A.M.; Luera, D.; Luo, S.; Rao, H. Autophagy regulator Atg9 is degraded by the proteasome. Biochem. Biophys. Res. Commun. 2020, 522, 254-258. [CrossRef] [PubMed]

365. Aiello, A.; Accardi, G.; Candore, G.; Gambino, C.M.; Mirisola, M.; Taormina, G.; Virruso, C.; Caruso, C. Nutrient sensing pathways as therapeutic targets for healthy ageing. Expert Opin. Ther. Targets 2017, 21, 371-380. [CrossRef] [PubMed]

366. Boland, B.; Kumar, A.; Lee, S.; Platt, F.M.; Wegiel, J.; Yu, W.H.; Nixon, R.A. Autophagy induction and autophagosome clearance in neurons: Relationship to autophagic pathology in Alzheimer's disease. J. Neurosci. 2008, 28, 6926. [CrossRef]

367. He, L.Q.; Lu, J.H.; Yue, Z.Y. Autophagy in ageing and ageing-associated diseases. Acta Pharmacol. Sin. 2013, 34, 605-611. [CrossRef]

368. Nixon, R.A.; Wegiel, J.; Kumar, A.; Yu, W.H.; Peterhoff, C.; Cataldo, A.; Cuervo, A.M. Extensive involvement of autophagy in Alzheimer disease: An immuno-electron microscopy study. J. Neuropathol. Exp. Neurol. 2005, 64, 113-122. [CrossRef]

369. Cai, Z.; Zhou, Y.; Liu, Z.; Ke, Z.; Zhao, B. Autophagy dysfunction upregulates beta-amyloid peptides via enhancing the activity of $\gamma$-secretase complex. Neuropsychiatr Dis Treat 2015, 11, 2091-2099. [CrossRef]

370. McDermott, J.R.; Gibson, A.M. Degradation of Alzheimer's beta-amyloid protein by human cathepsin D. Neuroreport 1996, 7, 2163-2166.

371. Papassotiropoulos, A.; Bagli, M.; Kurz, A.; Kornhuber, J.; Förstl, H.; Maier, W.; Pauls, J.; Lautenschlager, N.; Heun, R. A genetic variation of cathepsin D is a major risk factor for Alzheimer's disease. Ann. Neurol. 2000, 47, 399-403. [CrossRef]

372. Campanella, C.; Pace, A.; Caruso Bavisotto, C.; Marzullo, P.; Marino Gammazza, A.; Buscemi, S.; Palumbo Piccionello, A. Heat shock proteins in Alzheimer's disease: Role and targeting. Int. J. Mol. Sci. 2018, 19, 2603. [CrossRef]

373. Luo, G.R.; Le, W.D. Collective roles of molecular chaperones in protein degradation pathways associated with neurodegenerative diseases. Curr. Pharm. Biotechnol. 2010, 11, 180-187. [CrossRef] [PubMed]

374. Su, Y.; Chang, P.T. Acidic $\mathrm{pH}$ promotes the formation of toxic fibrils from beta-amyloid peptide. Brain Res. 2001, 893, 287-291.

375. Lanoiselée, H.-M.; Nicolas, G.; Wallon, D.; Rovelet-Lecrux, A.; Lacour, M.; Rousseau, S.; Richard, A.-C.; Pasquier, F.; Rollin-Sillaire, A.; Martinaud, O.; et al. APP, PSEN1, and PSEN2 mutations in early-onset Alzheimer disease: A genetic screening study of familial and sporadic cases. PLoS Med. 2017, 14, e1002270. [CrossRef] [PubMed]

376. Veugelen, S.; Saito, T.; Saido, T.C.; Chávez-Gutiérrez, L.; De Strooper, B. Familial Alzheimer's disease mutations in Presenilin generate amyloidogenic A $\beta$ peptide seeds. Neuron 2016, 90, 410-416. [CrossRef] [PubMed]

377. Esselens, C.; Oorschot, V.; Baert, V.; Raemaekers, T.; Spittaels, K.; Serneels, L.; Zheng, H.; Saftig, P.; De Strooper, B.; Klumperman, J.; et al. Presenilin 1 mediates the turnover of telencephalin in hippocampal neurons via an autophagic degradative pathway. J. Cell Biol. 2004, 166, 1041-1054. [CrossRef] [PubMed]

378. Katayama, T.; Imaizumi, K.; Sato, N.; Miyoshi, K.; Kudo, T.; Hitomi, J.; Morihara, T.; Yoneda, T.; Gomi, F.; Mori, Y.; et al. Presenilin-1 mutations downregulate the signalling pathway of the unfolded-protein response. Nat. Cell Biol. 1999, 1, 479-485. [CrossRef]

379. Jung, T.; Bader, N.; Grune, T. Lipofuscin. Ann. N. Y. Acad. Sci. 2007, 1119, 97-111.

380. Park, J.T.; Lee, Y.-S.; Cho, K.A.; Park, S.C. Adjustment of the lysosomal-mitochondrial axis for control of cellular senescence. Ageing. Res. Rev. 2018, 47, 176-182. [CrossRef]

381. Moreno-García, A.; Kun, A.; Calero, O.; Medina, M.; Calero, M. An overview of the role of lipofuscin in age-related neurodegeneration. Front Neurosci 2018, 12, 464. [CrossRef]

382. Moh, C.; Kubiak, J.Z.; Bajic, V.P.; Zhu, X.; Smith, M.A.; Lee, H.-g. Cell cycle deregulation in the neurons of Alzheimer's disease. In Cell Cycle in Development; Kubiak, J.Z., Ed.; Springer Berlin Heidelberg: Berlin/Heidelberg, Germany, 2011; pp. 565-576. 
383. Höhn, A.; Jung, T.; Grimm, S.; Catalgol, B.; Weber, D.; Grune, T. Lipofuscin inhibits the proteasome by binding to surface motifs. Free Radic. Biol. Med. 2011, 50, 585-591. [CrossRef]

384. Höhn, A.; Grune, T. Lipofuscin: Formation, effects and role of macroautophagy. Redox Biol. 2013, 1, $140-144$. [CrossRef] [PubMed]

385. Gao, M.; Monian, P.; Pan, Q.; Zhang, W.; Xiang, J.; Jiang, X. Ferroptosis is an autophagic cell death process. Cell Res. 2016, 26, 1021-1032. [CrossRef]

386. Schedin-Weiss, S.; Inoue, M.; Hromadkova, L.; Teranishi, Y.; Yamamoto, N.G.; Wiehager, B.; Bogdanovic, N.; Winblad, B.; Sandebring-Matton, A.; Frykman, S.; et al. Monoamine oxidase B is elevated in Alzheimer disease neurons, is associated with $\gamma$-secretase and regulates neuronal amyloid $\beta$-peptide levels. Alzheimers Res. Ther. 2017, 9, 57. [CrossRef] [PubMed]

387. Wang, Y.; Shi, Y.; Wei, H. Calcium dysregulation in Alzheimer's disease: A target for new drug development. J. Alzheimers Dis. Parkinsonism 2017, 7, 374. [CrossRef]

388. Wong, S.Y.; Tang, B.L. SIRT1 as a therapeutic target for Alzheimer's disease. Rev. Neurosci. 2016, $27,813-825$. [CrossRef] [PubMed]

389. McKee, A.C.; Kosik, K.S.; Kennedy, M.B.; Kowall, N.W. Hippocampal neurons predisposed to neurofibrillary tangle formation are enriched in type II calcium/calmodulin-dependent protein kinase. J. Neuropathol. Exp. Neurol. 1990, 49, 49-63. [CrossRef]

390. Wang, Y.J.; Chen, G.H.; Hu, X.Y.; Lu, Y.P.; Zhou, J.N.; Liu, R.Y. The expression of calcium/calmodulindependent protein kinase II-alpha in the hippocampus of patients with Alzheimer's disease and its links with AD-related pathology. Brain Res. 2005, 1031, 101-108. [CrossRef] [PubMed]

391. Beran, K. Budding of yeast cells, their scars and ageing. In Advances in Microbial Physiology; Rose, A.H., Wilkinson, J.F., Eds.; Academic Press: Cambridge, MA, USA, 1968; Volume 2, pp. 143-171.

392. Sorokin, M.I.; Knorre, D.A.; Severin, F.F. Early manifestations of replicative aging in the yeast Saccharomyces cerevisiae. Microb Cell 2014, 1, 37-42. [CrossRef]

393. Steinkraus, K.A.; Kaeberlein, M.; Kennedy, B.K. Replicative aging in yeast: The means to the end. Annu. Rev. Cell Dev. Biol. 2008, 24, 29-54. [CrossRef]

394. Tzur, A.; Moore, J.K.; Jorgensen, P.; Shapiro, H.M.; Kirschner, M.W. Optimizing optical flow cytometry for cell volume-based sorting and analysis. PLoS ONE 2011, 6, e16053. [CrossRef]

395. Zhang, H.; Komano, H.; Fuller, R.S.; Gandy, S.E.; Frail, D.E. Proteolytic processing and secretion of human beta-amyloid precursor protein in yeast. Evidence for a yeast secretase activity. J. Biol. Chem. 1994, 269, 27799-27802. [PubMed]

396. Moosavi, B.; Mousavi, B.; Macreadie, I.G. Yeast model of Amyloid- $\beta$ and tau aggregation in Alzheimer's disease. J. Alzheimer's Dis. Jad 2015, 47, 9-16. [CrossRef]

397. Almshawit, H.; Macreadie, I. Fungicidal effect of thymoquinone involves generation of oxidative stress in Candida glabrata. Microbiol. Res. 2017, 195, 81-88. [CrossRef]

398. Dhakal, S.; Subhan, M.; Fraser, J.M.; Gardiner, K.; Macreadie, I. Simvastatin efficiently reduces levels of Alzheimer's amyloid beta in yeast. Int. J. Mol. Sci. 2019, 20, 3531. [CrossRef] [PubMed]

399. Dhakal, S.; Macreadie, I. Tyramine and amyloid beta 42: A toxic synergy. Biomedicines 2020, 8, 145. [CrossRef]

400. Luu, Y.N.; Macreadie, I. Development of convenient system for detecting yeast cell stress, including that of amyloid beta. Int. J. Mol. Sci. 2018, 19, 2136. [CrossRef] [PubMed]

401. Sharma, V.; Jordan, J.J.; Ciribilli, Y.; Resnick, M.A.; Bisio, A.; Inga, A. Quantitative analysis of NF-кB transactivation specificity using a yeast-based functional assay. PLoS ONE 2015, 10, e0130170. [CrossRef]

Publisher's Note: MDPI stays neutral with regard to jurisdictional claims in published maps and institutional affiliations.

(C) 2020 by the authors. Licensee MDPI, Basel, Switzerland. This article is an open access article distributed under the terms and conditions of the Creative Commons Attribution (CC BY) license (http://creativecommons.org/licenses/by/4.0/). 